NUREG/CR-6335

ANL-95/15

Fatigue Strain-Life Behavior of Carbon and Low-Alloy Steels,

Austenitic Stainless Steels, and Alloy 600 in LWR Environments

Prepared by

J. Keisler, O. K. Chopra, W. J. Shack

Argonne National Laboratory

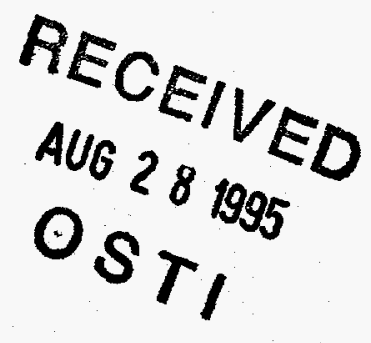

Prepared for

U.S. Nuclear Regulatory Commission 


\section{AVAILABILITY NOTICE}

Availability of Reference Materials Cited in NRC Publications

Most documents cited in NRC publications will be available from one of the following sources:

1. The NRC Public Document Room, 2120 L Street, NW., Lower Level, Washington, DC 20555-0001

2. The Superintendent of Documents, U.S. Government Printing Office, P. O. Box 37082 , Washington, DC 20402-9328

3. The National Technical Information Service, Springfield, VA 22161-0002

Although the listing that follows represents the majority of documents cited in NRC publications, it is not intended to be exhaustive.

Referenced documents available for inspection and copying for a fee from the NRC Public Document Room include NRC correspondence and internal NRC memoranda; NRC bulletins, circulars, information notices, inspection and investigation notices; licensee event reports; vendor reports and correspondence; Commission papers; and applicant and licensee documents and correspondence.

The following documents in the NUREG series are available for purchase from the Government Printing Office: formal NRC staff and contractor reports, NRC-sponsored conference proceedings, international agreement reports, grantee reports, and NRC booklets and brochures. Also available are regulatory guides, NRC regulations in the Code of Federal Regulations, and Nuclear Regulatory Commission Issuances.

Documents available from the National Technical Information Service include NUREG-series reports and technical reports prepared by other Federal agencies and reports prepared by the Atomic Energy Commission, forerunner agency to the Nuclear Regulatory Commission.

Documents available from public and special technical libraries include all open literature items, such as books, journal articles, and transactions. Federal Register notices. Federal and State legislation, and congressional reports can usually be obtained from these libraries.

Documents such as theses, dissertations, foreign reports and translations, and non-NRC conference proceedings are available for purchase from the organization sponsoring the publication cited.

Single coples of NRC draft reports are available free, to the extent of supply, upon written request to the Office of Administration, Distribution and Mail Services Section, U.S. Nuclear Regulatory Commission, Washington, DC 20555-0001.

Coples of industry codes and standards used in a substantive manner in the NRC regulatory process are maintalned at the NRC Library. Two White Flint North, 11545 Rockville Pike, Rockville, MD 20852-2738, for use by the public. Codes and standards are usually copyrighted and may be purchased from the originating organization or, if they are American National Standards, from the American National Standards Institute. 1430 Broadway, New York, NY 10018-3308.

\section{DISCLAIMER NOTICE}

This report was prepared as an account of work sponsored by an agency of the United States Government. Neither the United States Government nor any agency thereof, nor any of their employees, makes any warranty, expressed or implied, or assumes any legal liability or responsibility for any third party's use, or the results of such use, of any information, apparatus, product, or process disclosed in this report, or represents that its use by such third party would not infringe privately owned rights. 


\section{DISCLAIMER}

Portions of this document may be illegible in electronic image products. Images are produced from the best available original document. 


\section{Fatigue Stain-Life Behavior of Carbon and Low-Alloy Steels, Austenitic Stainless Steels, and Alloy 600 in LWR Environments}

Manuscript Completed: June 1995

Date Published: August 1995

Prepared by

J. Keisler, O. K. Chopra, W. J. Shack

Argonne National Laboratory

9700 South Cass Avenue

Argonne, IL 60439

\section{Prepared for}

Division of Engineering Technology

Office of Nuclear Regulatory Research

U.S. Nuclear Regulatory Commission

Washington, DC 20555-0001

NRC Job Code W6077 


\section{Previous Documents in Series}

Statistical Analysis of Fatigue Strain-Life Data for Carbon and Low-Alloy Steels, NUREG/CR6237, ANL-94/21 (August 1994). 


\title{
Fatigue Strain-Life Behavior of Carbon and Low-Alloy Steels, Austenitic Stainless Steels, and Alloy 600 in LWR Environments
}

\author{
by
}

\author{
J. Keisler, O. K. Chopra, and W. J. Shack
}

\begin{abstract}
The existing fatigue strain vs. life (S-N) data, foreign and domestic, for carbon and low-alloy steels, austenitic stainless steels, and Alloy 600 used in the construction of nuclear power plant components have been compiled and categorized according to material, loading, and environmental conditions. Statistical models have been developed for estimating the effects of the various service conditions on the fatigue life of these materials. The results of a rigorous statistical analysis have been used to estimate the probability of initiating a fatigue crack. Data in the literature were reviewed to evaluate the effects of size, geometry, and surface finish of a component on its fatigue life. The fatigue $\mathrm{S}-\mathrm{N}$ curves for components have been determined by adjusting the probability distribution curves for smooth test specimens for the effect of mean stress and applying design margins to account for the uncertainties due to component size/geometry and surface finish. The significance of the effect of environment on the current Code design curve and on the proposed interim design curves published in NUREG/CR-5999 is discussed. Estimations of the probability of fatigue cracking in sample components from BWRs and PWRs are presented.
\end{abstract}









\section{Contents}

Nomenclature

Executive Summary xiii

Acknowledgments xiv

1 Introduction 1

2 Overview of Fatigue Strain-Life Data .......................................................... 2

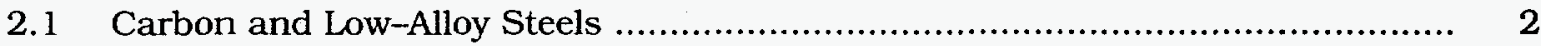

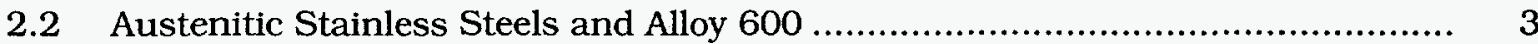



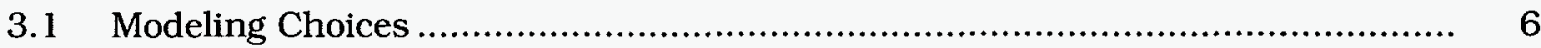

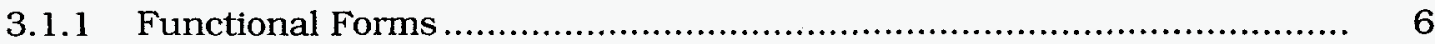

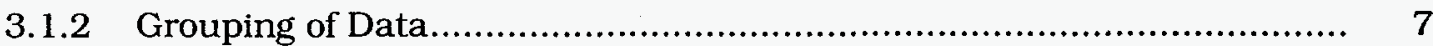

3.2 Least-Squares Modeling within a Fixed Structure ................................. 7

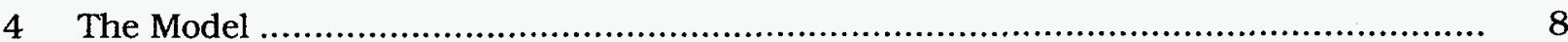

4.1 Carbon and Low-Alloy Steels ......................................................... 8

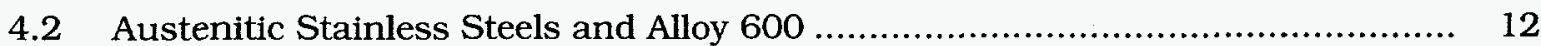



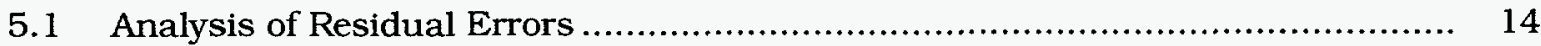

5.2 Statistical Significance of Parameter Values ........................................ 19

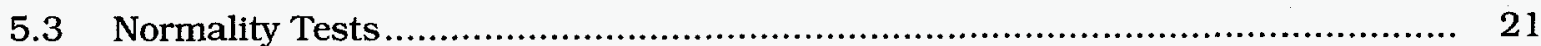

$6 \quad$ Probability Distributions of Fatigue Life ................................................... 22

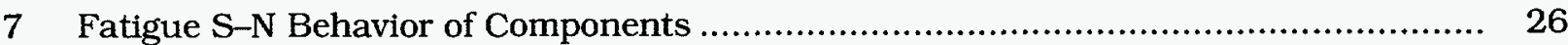

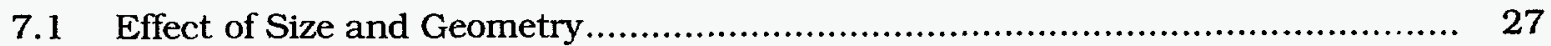

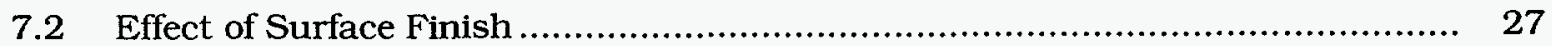


8 Conclusions

References

Appendix

Estimation of Probability of Fatigue Cracking in Reactor Components.

\section{Figures}

1. Fatigue S-N data for carbon steels in water

2. Experimental and predicted values of fatigue life of carbon and low-alloy steels in air and water environments

3. Fatigue S-N behavior for carbon and low-alloy steels estimated from the model and determined experimentally in air at room temperature and $290^{\circ} \mathrm{C}$.

4. Experimental and predicted values of fatigue life of austenitic stainless steels and Alloy 600 in air and water environments

5. Fatigue $\mathrm{S}-\mathrm{N}$ behavior for Types 304 and 316 stainless steel and Alloy 600 estimated from the model and determined experimentally in air.

6. Residual error for carbon and low-alloy steels as a function of test temperature ....

7. Residual error for carbon and low-alloy steels plotted as a function of material heat.

8. Residual error for carbon and low-alloy steels as a function of sulfur content of the steel.

9. Residual error for carbon and low-alloy steels as a function of loading strain rate

10. Residual error for carbon and low-alloy steels as a function of applied strain amplitude

11. Residual error for carbon and low-alloy steels as a function of dissolved oxygen in water

12. Residual error for austenitic stainless steels as a function of test temperature .......

13. Residual error for austenitic stainless steels plotted as a function of material heat. 
14. Residual error for austenitic stainless steels as a function of applied strain amplitude

15. Residual error for austenitic stainless steels as a function of dissolved oxygen in water

16. Residual error for Alloy 600 as a function of test temperature

17. Residual error for Alloy 600 plotted as a function of material heat.

18. Residual error for Alloy 600 as a function of applied strain amplitude

19. Experimental data and probability of fatigue crack initiation in carbon and lowalloy steel test specimens in air at room temperature and $290^{\circ}$

20. Experimental data and probability of fatigue crack initiation in carbon and lowalloy steel test specimens in PWR environment

21. Experimental data and probability of crack initiation for Types 304, 316, and $316 \mathrm{NG}$ stainless steel test specimens in air environment

22. Experimental data and probability of crack initiation for Types 304 and $316 \mathrm{NG}$ stainless steel test specimens in water environment.

23. Experimental data and probability of crack initiation for Alloy 600 test specimens in air and water environments

24. Adjustment for mean stress effects and factors of 2 and 20 applied to best-fit S$\mathrm{N}$ curves for carbon and low-alloy steels to obtain the ASME Code design fatigue curve

25. Procedure for translating probability distribution on fatigue life of laboratory test specimens to those of actual reactor components

26. Probability of fatigue cracking in carbon and low-alloy steel vessel in roomtemperature water

27. Probability of fatigue cracking in carbon and low-alloy steels in air at $290^{\circ} \mathrm{C}$, and the ASME Code design curve

28. Probability of fatigue cracking in carbon and low-alloy steels in PWR water, the proposed interim design curve in water with $<0.1 \mathrm{ppm}$ DO, and the ASME design curve.

29. Probability of fatigue cracking in carbon and low-alloy steels at 200,250 , and $290^{\circ} \mathrm{C}$ and $0.001 \% / \mathrm{s}$ strain rate in water with DO levels $\geq 0.5 \mathrm{ppm}$, the proposed interim design curve for carbon steel in water with $>0.1 \mathrm{ppm} \mathrm{DO}$, and the ASME design curve

30. Probability of fatigue cracking in carbon and low-alloy steels at $290^{\circ} \mathrm{C}$ and $0.1 \% / \mathrm{s}$ strain rate in water with DO levels $\geq 0.5 \mathrm{ppm}$, the proposed interim design curve for carbon steel in water with $>0.1 \mathrm{ppm}$ DO, and the ASME design curve. 
31. Probability of fatigue cracking in austenitic stainless steels in air and water environments at $290^{\circ} \mathrm{C}$

32. Probability of fatigue cracking in Alloy 600 in air and water environments at $290^{\circ} \mathrm{C}$

A-1. Proposed interim fatigue design curves for carbon and low-alloy steels in lowDO water typical of PWRs and high-DO water representing a conservative estimate for BWRs

A-2. Proposed interim fatigue design curve for austenitic stainless steels in water

A-3. Probability of fatigue cracking in carbon steel in water with low DO levels $(<0.05 \mathrm{ppm})$ plotted as a function of cumulative usage factor at different applied stress amplitudes

A-4. Probability of fatigue cracking in low-alloy steel in water with low DO levels $(<0.05 \mathrm{ppm})$ plotted as a function of cumulative usage factor at different applied stress amplitudes

A-5. Probability of fatigue cracking in carbon steel in water with DO levels $\geq 0.5 \mathrm{ppm}$ plotted as a function of cumulative usage factor at different applied stress amplitudes

A-6. Probability of fatigue cracking in low-alloy steel in water with DO levels $\geq 0.5 \mathrm{ppm}$ plotted as a function of cumulative usage factor at different applied stress amplitudes

A-7. Probability of fatigue cracking in Types 304 and 316 stainless steel in water plotted as a function of cumulative usage factor at different applied stress amplitudes

A-8. Probability of fatigue cracking in Alloy 600 in water plotted as a function of cumulative usage factor at different applied stress amplitudes....

\section{Tables}

1. Data base for fatigue $\mathrm{S}-\mathrm{N}$ behavior of carbon and low-alloy steels

2. Chemical and strength specifications for carbon and low-alloy steels

3. Characterization of existing $\mathrm{S}-\mathrm{N}$ data for several heats of austenitic stainless steel in air at various temperatures

4. Characterization of existing $\mathrm{S}-\mathrm{N}$ data for several heats of austenitic stainless steel in water at various temperatures

5. Existing fatigue S-N data for several heats of Alloy 600 in air and water environments 
6. Estimates of factor by which fatigue life is changed by varying a specific variable...

7. Standard error and t-statistic for the coefficients of various parameters in the statistical model for carbon and low-alloy steels

8. Standard error and t-statistic for the coefficients of various parameters in the statistical models for austenitic stainless steels and for Alloy 600

9. Results of normality tests for carbon and low-alloy steels, austenitic stainless steels, and Alloy 600

10. Standard deviation of distance from mean $\mathrm{S}-\mathrm{N}$ curve for the different materials.....

11. Typical average roughness values for surfaces finished by various processes

12. Values of elastic modulus for carbon and low-alloy steels, austenitic stainless steels, and Alloy 600, MPa (x1000 ksi)

A-1 Allowable cycles and probability of fatigue cracking in low-alloy steel components in PWR water as a function of cumulative usage factor at different applied stress amplitudes

A-2 Allowable cycles and probability of fatigue cracking in low-alloy steel componerits in high-dissolved oxygen water as a function of cumulative usage factor at different applied stress amplitudes

A-3 Allowable cycles and probability of fatigue cracking in carbon steel components in PWR water as a function of cumulative usage factor at different applied stress amplitudes

A-4 Allowable cycles and probability of fatigue cracking in carbon steel components in high-dissolved oxygen water as a function of cumulative usage factor at different applied stress amplitudes

A-5 Allowable cycles and probability of fatigue cracking in austenitic stainless steel components in water as a function of cumulative usage factor at different applied stress amplitudes....

A-6 Allowable cycles and probability of fatigue cracking in Alloy 600 components in water as a function of cumulative usage factor at different applied stress amplitudes

A-7. Inverse of standard cumulative distribution function

A-8. Fatigue evaluation for SA-508 Class 2 low-alloy steel inlet nozzle of PWR vessel ...

A-9. Fatigue evaluation for SA-508 Class 2 low-alloy steel outlet nozzle of PWR vessel

A-10. Fatigue evaluation for Type 316 stainless steel surge line of a PWR

A-11. Fatigue evaluation for Type 316 stainless steel safe end for safety injection nozzle of a PWR 
A-12. Fatigue evaluation for Type 316 stainless steel reducing tee from decay heat removal system of a PWR

A-13. Fatigue evaluation for Alloy 600 instrumentation penetration weld of PWR lower head

A-14. Fatigue evaluation for SA-333 Grade 6 carbon steel piping for residual heat removal suction line of a BWR

A-15. Fatigue evaluation for SA-333 Grade 6 carbon steel elbow from BWR feedwater line piping

A-16. Fatigue evaluation for SA-508 low-alloy steel feedwater nozzle of a BWR

A-17. Fatigue evaluation for Alloy 600 thermal sleeve from BWR vessel feedwater nozzle 


\section{Nomenclature}

$\varepsilon_{\mathrm{a}} \quad$ Applied strain amplitude (\%)

$\dot{\varepsilon} \quad$ Applied total strain rate $(\% / \mathrm{s})$

$\dot{\varepsilon}^{*} \quad$ Transformed total strain rate

$\sigma_{\mathrm{u}} \quad$ Ultimate strength of steel (MPa)

$\sigma_{y} \quad$ Yield strength of steel (MPa)

DO Dissolved oxygen in water (ppm)

E Young's modulus

$\mathrm{F}^{-1}[\mathrm{x}]$ Inverse of standard normal cumulative distribution function

I316NG Indicator for austenitic steel type. It is 1 for Type 316 Nuclear Grade stainless steel and is 0 otherwise

IS Indicator for ferritic steel type. It is 1 for carbon steel and 0 for low-alloy steel

IT Indicator for Alloy 600. It is 0 for temperatures $<150^{\circ} \mathrm{C}$ and is 1 for temperatures between $150-320^{\circ} \mathrm{C}$

$\mathrm{I}_{\mathrm{W}} \quad$ Indicator for water environment. It is 1 for water and 0 for air environment

$\mathrm{K}_{\mathrm{N}} \quad$ Factor applied on life to account for uncertainties in relating fatigue lives of smooth test specimens to those of reactor components

$\mathrm{K}_{\mathrm{S}} \quad$ Factor applied on strain to account for uncertainties in relating fatigue lives of smooth test specimens to those of reactor components

$\mathrm{N}_{25} \quad$ Fatigue life defined as number of cycles for peak tensile stress to drop $25 \%$ from its initial value

$\mathrm{N}_{25}(\mathrm{x}) \quad \mathrm{xth}$ percentile of probability distribution on life for smooth test specimens

$\mathrm{N}_{\mathrm{i}}(\mathrm{x}) \quad$ Number of cycles corresponding to $\mathrm{xth}$ percentile of probability for fatigue crack initiation in a component

$\mathrm{O}^{*} \quad$ Transformed dissolved oxygen (ppm)

$\mathrm{R} \quad$ Strain ratio

$\mathrm{R}_{\mathrm{a}} \quad$ Average surface roughness, defined as the arithmetic mean deviation of surface height from mean line through profile 
$\mathrm{R}_{\mathrm{q}} \quad \mathrm{RMS}$ surface roughness, defined as the root-mean-square deviation of surface profile from mean line

S Sulfur content of steel (wt.\%)

$\mathrm{S}^{*} \quad$ Transformed sulfur content (wt.\%)

$\mathrm{S}_{\mathrm{a}} \quad$ Applied stress amplitude (MPa)

$\mathrm{S}_{\mathrm{a}}^{\prime} \quad$ Value of stress amplitude adjusted for mean stress (MPa)

T Test temperature $\left({ }^{\circ} \mathrm{C}\right)$

$\mathrm{T}^{*} \quad$ Transformed temperature $\left({ }^{\circ} \mathrm{C}\right)$

$\mathrm{x} \quad$ Percentile of probability distribution

$\mathrm{X} \quad$ Failure criteria defined as 25,50 , or $100 \%$ decrease in peak tensile stress 


\section{Executive Summary}

The current ASME Code Section III design fatigue curves were based primarily on straincontrolled fatigue tests of small polished specimens at room temperature in air. Best-fit curves to the experimental test data were lowered by a factor of 2 on stress or a factor of 20 on cycles, whichever was more conservative, to obtain the design fatigue curves. The factors were intended to account for differences and uncertainties in relating the fatigue lives of laboratory test specimens to those of actual reactor components. However, environmental effects on fatigue resistance of materials were not explicitly addressed in these design fatigue curves.

Recent fatigue strain vs. life (S-N) data illustrate potentially significant effects of light water reactor (LWR) environments on the fatigue resistance of materials. Specimen lives in simulated LWR environments can be much shorter than those for corresponding tests in air. Under certain conditions of loading and environment, fatigue lives in the test environments can be more than a factor of 100 shorter than those for the tests in air. These results raise the issue of whether the fatigue design curves in Section III are appropriate for the purposes intended and whether they adequately account for environmental effects on fatigue behavior.

This report presents a statistical analysis of existing fatigue $\mathrm{S}-\mathrm{N}$ data for carbon steel (CS) and low-alloy steel (LAS), austenitic stainless steels (SSs), and Alloy 600, to evaluate the significance of environmental effects on fatigue $\mathrm{S}-\mathrm{N}$ behavior. The existing fatigue $\mathrm{S}-\mathrm{N}$ data, foreign and domestic, for materials used in the construction of nuclear power plant components have been compiled and categorized according to various test parameters. Statistical models have been developed for estimating the effects of various material, loading, and environmental conditions on fatigue life of these materials. The results of a rigorous statistical analysis have been used to estimate the probability of fatigue cracking in smooth test specimens. Fatigue S$\mathrm{N}$ curves for components have been determined by adjusting the best-fit experimental curve for the effect of mean stress and setting margins for size, geometry, and surface finish to the probability distribution curves for test specimens. Data available in the literature were reviewed to evaluate the effects of size, geometry, and surface finish of a component on its fatigue life. The data indicate that a factor of $\approx 4$ may be used to account for size/geometry and surface roughness of the component.

For a specific service condition, the interim design curves represent a lower probability of cracking in CS components (1-5\% probability) than in LAS components (5-25\% probability). The interim design curve for SSs represents 5-20\% probability of cracking in water. Probability of fatigue cracking for Type 316 NG components is somewhat lower than that for Types 304 and 316 SS. The interim design curves may be somewhat conservative for Alloy 600 at stress levels above $50 \mathrm{ksi}(345 \mathrm{MPa})$.

The statistical models have also been used to assess the significance of the proposed interim fatigue design curves published in NUREG/CR-5999 on fatigue evaluation of reactor components. The probability of fatigue cracking in CS and LAS, austenitic SS, and Alloy 600 components has been estimated as a function of cumulative usage factor for various service conditions. Estimations of the probability of fatigue cracking in sample components from boiling water reactors and pressurized water reactors are presented. 


\section{Acknowledgments}

This work was supported by the Engineering Issues Branch, Office of Nuclear Regulatory Research (RES), U.S. Nuclear Regulatory Commission (NRC), under FIN Number W6077-3; Project Manager: Craig Hrabal. The authors thank Lee Abramson, Ron Whitfield, and Mariska Absil for their helpful discussions. This work is directly related to an NRC-sponsored program at Argonne National Laboratory on fatigue of austenitic and ferritic steels under simulated LWR operating conditions. The related research, titled "Environmentally Assisted Cracking and Fatigue in LWR Systems," is being carried out under the Materials Engineering Branch, RES, FIN Number A2212. 


\section{Introduction}

The ASME Boiler and Pressure Vessel Code Section III, ${ }^{1}$ Subsection NB, contains rules for the construction of Class 1 components. Figure I-9.0 of Appendix I to Section III specifies the code design fatigue curves that are to be used. However, Section III, Subsection NB-3121, of the Code states that environmental effects on fatigue resistance of a material are not explicitly addressed in these design curves. Therefore, there is uncertainty about the environmental effects on fatigue resistance of materials for operating pressurized water reactor (PWR) and boiling water reactor (BWR) plants, whose primary-coolant-pressure-boundary components are constructed as specified in Section III of the Code.

Current Section III design fatigue curves were based on strain-controlled tests of small polished specimens at room temperature (RT) in air. ${ }^{2}$ To obtain the design fatigue curves, best-fit curves to the experimental test data were lowered by a factor of 2 on stress or 20 on cycles, whichever was more conservative, at each point on the best-fit curve. As described in the Section III criteria document, these factors were intended to account for the differences and uncertainties in relating the fatigue lives of laboratory test specimens to those of actual reactor components. The factor of 20 on cycles is the product of three separate subfactors: 2 for scatter of data (minimum to mean), 2.5 for size effects, and 4 for surface finish, atmosphere, etc. ${ }^{3}$ "Atmosphere" was intended to reflect the effects of an industrial environment rather than the controlled environment of a laboratory. The effects of the coolant environment are not explicitly addressed in the Code design curves. Furthermore, the probability distribution on fatigue life is not defined in the Code design fatigue curves. The best-fit or mean curves to the experimental data represent a $50 \%$ probability of initiating a fatigue crack in a small polished test specimen. It is not clear whether the Code design curve represents greater than, equal to, or less than $50 \%$ probability of initiating a fatigue crack in power plant components.

Recent fatigue strain-vs.-life (S-N) data from the United States ${ }^{4-15}$ and Japan ${ }^{16-18}$ show that light water reactor (LWR) environments can have potentially significant effects on the fatigue resistance of carbon steel (CS) and low-alloy steel (LAS). Fatigue lives in simulated LWR environments can be much shorter than the lives determined by corresponding tests in air, Fig. 1. Under certain conditions of loading and environment, e.g., temperature $>250^{\circ} \mathrm{C}$, dissolved oxygen (DO) $>0.1 \mathrm{ppm}$, strain rate $<0.01 \% / \mathrm{s}$, and sulfur content in the steel $\geq 0.006 \mathrm{wt} . \%$, fatigue lives in the test environments can be a factor of 100 shorter than those for

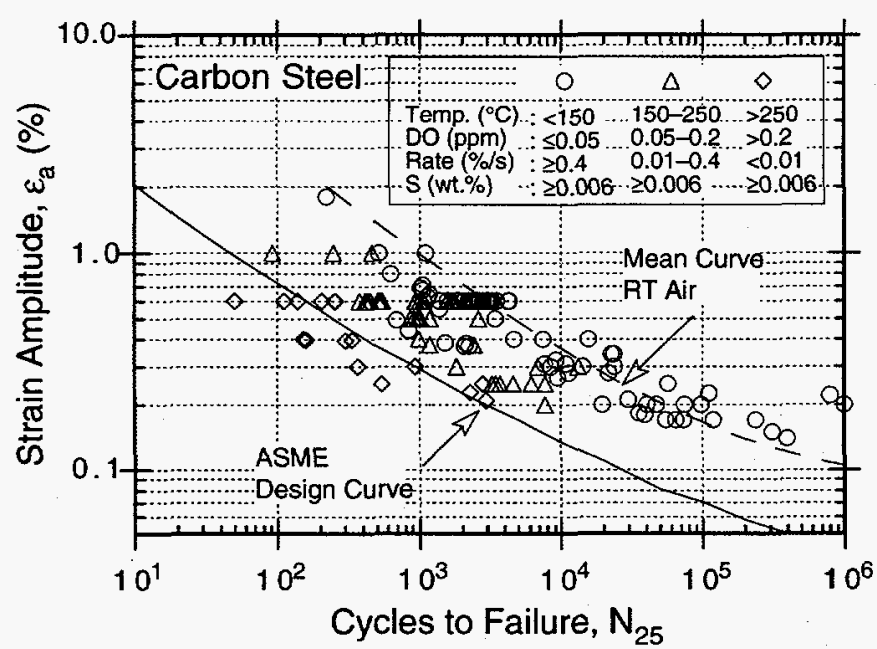

Figure 1.

Fatigue $S-N$ data for carbon steels in water 
the tests in air. This implies that the factors of 2 and 20 applied to the mean-data curve may not be adequate. Based on the existing fatigue S-N data, Argonne National Laboratory (ANL) has developed interim design fatigue curves that explicitly address environmental effects on fatigue life of CSs and LASs and austenitic stainless steels (SSs). 19

The objectives of this report are to obtain the probability distribution on fatigue life for materials used in the construction of nuclear power plant components and to quantify the contributions of various material, loading, and environmental variables that influence the fatigue resistance of these alloys. Existing fatigue $\mathrm{S}-\mathrm{N}$ data, foreign and domestic, for carbon and low-alloy ferritic steels, austenitic SSs, and Alloy 600 have been compiled and categorized according to different test conditions. For each type of material, statistical models have been developed for estimating the effects of various material, loading, and environmental variables on their fatigue life. The model for CSs and LASs presented in this report is a modified version of the model presented earlier in NUREG/CR-6237.20 Results of the statistical analysis have been used to estimate the probability of fatigue cracking. The contributions of material and environmental conditions that have not been considered in the existing fatigue $\mathrm{S}-\mathrm{N}$ data base, such as size, geometry, and surface finish, are discussed. Fatigue S-N curves that are applicable to reactor components have been determined by applying design margins to the probability distribution curves to account for the uncertainties due to component size/geometry and surface finish, and adjusting the curves for the effect of mean stress. The significance of the effect of environment on the proposed interim fatigue design curves presented in NUREG/CR5999 is discussed.

\section{Overview of Fatigue Strain-Life Data}

\subsection{Carbon and Low-Alloy Steels}

The primary sources of relevant S-N data are the tests performed by General Electric Co. (GE) in a test loop at the Dresden 1 reactor 4.5 and with the Electric Power Research Institute (EPRI), 6,7 the work of Terrell at Mechanical Engineering Associates (MEA), ${ }^{8-10}$ the ongoing program at ANL on fatigue of pressure vessel and piping steels, ${ }^{11-15}$ and the JNUFAD* data base for "Fatigue Strength of Nuclear Plant Component" from Japan, including the published work of Higuchi, Kobayashi, and lida. 16-18 In addition, fatigue tests have been conducted by Babcock and Wilcox (B\&W) in water chemistries that are characteristic of fossil-fired boilers. ${ }^{21}$ Although the B\&W data exhibit trends similar to those observed in LWR environments, the B\&W data were not considered in this study.

Only fatigue data obtained on smooth specimens tested under fully reversed loading conditions, i.e., $R=-1$, were considered in this analysis; tests on notched specimens or at $R$ values other than -1 were excluded. Details of the fatigue data from different sources are given in Table 1. The ASME Specifications for chemical and tensile strength requirements for these steels are listed in Table 2. The data base is composed of 456 tests in air (345 tests for LAS and 111 for CS) and 409 tests in water (270 tests for LAS and 139 for CS). Carbon steels include nine different heats of A333-Grade 6, A106-Grade B, A516-Grade 70, and A508-Class 1 steel, while the low-alloy steels include 14 heats of A533-Grade B and A508-Class 2 and 3

\footnotetext{
* Private communication from M. Higuchi, Ishikawajima-Harima Heavy Industries Co., Japan, to M. Prager of the Pressure Vessel Research Council, 1992. The old data base "FADAL" has been revised and renamed "JNUFAD."
} 
Table 1. Data base for fatigue S-N behavior of carbon and low-alloy steels

\begin{tabular}{|c|c|c|c|c|c|c|}
\hline \multirow[b]{2}{*}{ Source } & \multirow[b]{2}{*}{ Reference } & \multicolumn{2}{|c|}{ Steel Type } & \multirow{2}{*}{$\begin{array}{l}\text { No. of } \\
\text { Heats }\end{array}$} & \multicolumn{2}{|c|}{ Number of Tests ${ }^{\mathrm{a}}$} \\
\hline & & Carbon Steel & Low-Alloy Steel & & In Air & In Water \\
\hline \multirow[t]{2}{*}{ ANL } & $11-14$ & A106-Gr B & & 1 & $16(1)$ & $16(1)$ \\
\hline & & & A533-Gr B & 1 & $16(1)$ & $21(1)$ \\
\hline \multirow[t]{2}{*}{$\mathrm{GE}$} & $4-7$ & A516-Gr 70 & & 1 & $8(1)$ & $14(1)$ \\
\hline & & A333-Gr 6 & & 1 & $14(1)$ & \\
\hline \multirow[t]{5}{*}{ Japan } & JNUFAD & A333-Gr 6 & & 4 & $37(3)$ & $91(3)$ \\
\hline & & $\mathrm{A} 508-\mathrm{Cl} 1$ & & 1 & & $14(1)$ \\
\hline & & & A533-Gr B & 5 & $106(5)$ & $62(2)$ \\
\hline & & & $\mathrm{A} 508-\mathrm{C} 12$ & 1 & $28(1)$ & $26(1)$ \\
\hline & & & $\mathrm{A} 508-\mathrm{Cl} 3$ & 7 & $195(7)$ & $147(2)$ \\
\hline \multirow[t]{2}{*}{ MEA } & $8-10$ & Al06-Gr B & & 1 & 36 (1) & $18(1)$ \\
\hline & & & & Total: & 456 & 409 \\
\hline
\end{tabular}

a The number within parentheses represents the number of heats used for the tests.

steels. Most of the data have been obtained on cylindrical specimens tested under axial straincontrol mode with a triangle or sawtooth waveform. The specimen diameters range from 6 to $10 \mathrm{~mm}$ and gauge lengths range from 8 to $25 \mathrm{~mm}$ (tests conducted on hourglass samples were excluded from the analysis). Some of the tests were conducted under load control (15\% of the tests in air and 9\% in water). The GE tests in the Dresden 1 reactor were conducted in bending with a trapezoidal waveform.

In most studies, the fatigue life of a test specimen is defined as the number of cycles for the peak tensile stress to drop $25 \%$ from its initial value. For the specimen sizes used in these studies (6 to 10-mm diameter), a $25 \%$ drop in peak tensile stress corresponds to a 3-mm-deep crack, i.e., $\mathrm{N}_{25}$ represents the number of cycles to initiate an approximately 3-mm crack. The fatigue lives defined by other failure criteria, e.g., 50\% deciease in peak tensile stress or complete failure, were normalized according to the equation

$$
\mathrm{N}_{25}=\mathrm{N}_{\mathrm{X}} /(0.947+0.00212 \mathrm{X}) \text {, }
$$

where $X$ is the failure criteria, i.e., 25,50 , or $100 \%$ decrease in peak tensile stress. The strain rates for the tests conducted with a sine waveform were represented by average values.

\subsection{Austenitic Stainless Steels and Alloy 600}

The primary sources of relevant S-N data for austenitic SSs and Alloy 600 are the JNUFAD data base for "Fatigue Strength of Nuclear Plant Component" from Japan and the data compiled by Jaske and O'Donnell 22 for developing fatigue design criteria for pressure vessel alloys. Fatigue tests by Conway et al. ${ }^{23}$ and Keller $^{24}$ on Types 304 and 316 SSs in air were also included in the data base. In addition, tests in water have been conducted on austenitic SSs by General Electric Co. (GE) in a test loop at the Dresden 1 reactor 4,5 and at ANL. 25 Only fatigue data obtained on smooth specimens tested under fully reversed loading conditions were considered in the statistical analysis; tests on notched specimens or at $\mathrm{R}$ values other than -1 were excluded. Fatigue tests on sensitized austenitic SSs were also excluded from the analysis. Details of the fatigue S-N data for austenitic SSs are given in Tables 3 and 4 and for Alloy 600 in Table 5. 
Table 2. Chemical and strength specifications for carbon and low-alloy steels

\begin{tabular}{|c|c|c|c|c|c|c|c|}
\hline Variable & $\begin{array}{l}\mathrm{SA}-106 \\
\text { Grade B }\end{array}$ & $\begin{array}{l}\text { SA-333 } \\
\text { Grade } 6 \\
\end{array}$ & $\begin{array}{l}\text { SA-516 } \\
\text { Grade } 70 \\
\end{array}$ & $\begin{array}{l}\text { SA-508 } \\
\text { Class 1a }\end{array}$ & $\begin{array}{l}\text { SA-508 } \\
\text { Class } 2\end{array}$ & $\begin{array}{l}\text { SA-508 } \\
\text { Class } 3\end{array}$ & $\begin{array}{l}\mathrm{SA}-533 \\
\text { Grade B }\end{array}$ \\
\hline Steel Type & Carbon & Carbon & Carbon & Carbon & Alloy & Alloy & Low-Alloy \\
\hline Product & $\begin{array}{l}\text { Seamless } \\
\text { Pipes }\end{array}$ & $\begin{array}{l}\text { Seamless } \\
\& \text { Welded } \\
\text { Pipes }\end{array}$ & $\begin{array}{l}\text { PV } \\
\text { Plates }\end{array}$ & $\begin{array}{l}\text { PV } \\
\text { Forgings }\end{array}$ & $\begin{array}{l}\text { PV } \\
\text { Forgings }\end{array}$ & $\begin{array}{l}\text { PV } \\
\text { Forgings }\end{array}$ & $\begin{array}{l}\text { PV } \\
\text { Plates }\end{array}$ \\
\hline $\mathrm{C} \max .(\%)$ & $0.25^{a}$ & $0.30^{\mathrm{b}}$ & $0.27-0.31^{c}$ & 0.30 & 0.27 & 0.25 & 0.25 \\
\hline $\mathrm{Cr}(\%)$ & $0.40 \max .^{d}$ & - & - & $0.25 \max$ & $0.25-0.45$ & $0.25 \max$. & - \\
\hline $\mathrm{Cu}(\%)$ & $0.40 \max .^{d}$ & - & - & - & - & - & - \\
\hline Mn (\%) & $0.27-0.93$ & $0.29-1.06$ & $0.79-1.30$ & $0.70-1.35$ & $0.50-1.00$ & $1.20-1.50$ & $1.07-1.62^{\mathrm{e}}$ \\
\hline Mo (\%) & $0.15 \max .^{d}$ & - & - & 0.10 max. & $0.55-0.70$ & $0.45-0.60$ & $0.41-0.64$ \\
\hline $\mathrm{Ni}(\%)$ & $0.40 \max .^{d}$ & - & - & 0.40 max. & $0.50-1.00$ & $0.40-1.00$ & $0.37-0.73$ \\
\hline $\mathrm{P} \max .(\%)$ & 0.025 & 0.048 & 0.035 & 0.025 & 0.025 & 0.025 & 0.035 \\
\hline $\mathrm{S} \max .(\%)$ & 0.025 & 0.058 & 0.040 & 0.025 & 0.025 & 0.025 & 0.040 \\
\hline Si $(\%)$ & $0.10 \mathrm{~min}$. & $0.10 \mathrm{~min}$. & $0.13-0.45$ & $0.15-0.40^{f}$ & $0.15-0.40^{\mathrm{e}}$ & $0.15-0.40^{\mathrm{e}}$ & $0.13-0.45$ \\
\hline V (\%) & $0.08 \max ^{d}$ & - & - & $0.05 \max$ & $0.05 \max$ & $0.05 \max$ & - \\
\hline $\begin{array}{l}\text { Tensile } \\
\text { Strength } \\
\text { (MPa) }\end{array}$ & $415 \mathrm{~min}$. & 415 min. & $485-620$ & $485-655$ & $550-725$ & $550-725$ & $\begin{array}{l}550-6909 \\
620-795 \\
690-860\end{array}$ \\
\hline $\begin{array}{l}\text { Yield } \\
\text { Strength } \\
\text { (MPa) }\end{array}$ & 240 min. & 240 min. & $260 \mathrm{~min}$. & $250 \mathrm{~min}$. & 345 min. & 345 min. & $\begin{array}{l}345 \text { min.g } \\
485 \text { min. } \\
570 \text { min. }\end{array}$ \\
\hline $\begin{array}{l}\text { Heat } \\
\text { Treatment }\end{array}$ & 1 & 2 & 3 & 4 & 4 & 4 & 5 \\
\hline $\begin{array}{l}\text { a For each red } \\
\text { maximum o } \\
\text { b For each re } \\
\text { maximum w } \\
\text { c Maximum an } \\
\text { d These five de } \\
\text { e The maximu } \\
\text { are specified } \\
\text { f When vacuur } \\
\text { maximum. } \\
\text { g The three set } \\
\text { h Heat treatme } \\
\text { 1. Hot-finis } \\
650^{\circ} \mathrm{C} \text { or } \\
\text { 2. All seaml } \\
\text { following: } \\
\text { 3. Plates } 40 \\
\text { normalize } \\
\text { Specificat } \\
\text { 4. The forgir } \\
\text { suitable } 1 \\
\text { temperat } \\
\text { 5. All plates } \\
\text { obtain ur } \\
\text { suitable } t \\
\text { less than }\end{array}$ & $\begin{array}{l}\text { eduction of } 0.01 \\
\text { of } 1.35 \% \text { Mn. } \\
\text { eduction of } 0.0 \\
\text { will be permitted } \\
\text { umount increase } \\
\text { lesignated eleme } \\
\text { um Mn content } \\
\text { d and when Sur } \\
\text { im carbon-deox } \\
\text { ets of numbers } \\
\text { lents for the var } \\
\text { shed pipe need } \\
\text { r higher. } \\
\text { less and welde } \\
\text { g: normalize and } \\
0 \text { mm and unde } \\
\text { zed or stress r } \\
\text { ation SA-516 for } \\
\text { ings shall be he } \\
\text { liquid medium } \\
\text { ture and holdin } \\
\text { is shall be heat } \\
\text { iniform tempera } \\
\text { temperature no } \\
\text { n } 1 / 2 \mathrm{~h} \text {. }\end{array}$ & $\begin{array}{l}1 \% \text { below } 0.3 \\
01 \% \text { below th } \\
\text { ed up to a max } \\
\text { es with increa } \\
\text { ents combine } \\
\text { t may be incr } \\
\text { ppplementary } \\
\text { xidation is rec } \\
\text { correspond to } \\
\text { rious steels ar } \\
1 \text { not be heat } \\
\text { ed pipes shall } \\
\text { d temper, que } \\
\text { ler in thicknes } \\
\text { elieved, or bc } \\
\text { r details. } \\
\text { eated to a tem } \\
\text { by spraying } \\
\text { ng for a time o } \\
\text { treated by he } \\
\text { ature and the }\end{array}$ & $\begin{array}{l}\text { \%, an increas } \\
\text { specified } \mathrm{C} n \\
\text { mum of } 1.35 \% \\
\text { ing section thic } \\
\text { shall not exce } \\
\text { ased to } 1.65 \% \\
\text { iequirements } \mathrm{S} \\
\text { dired by Supple } \\
\text { Class } 1,2 \text {, and } \\
\text { as follows: } \\
\text { treated, and co } \\
\text { be treated to c } \\
\text { lch and temper } \\
\text { are normally } \\
\text { th. Plates ove } \\
\text { perature which } \\
\mathrm{r} \text { immersion. } \\
1 / 2 \mathrm{~h} \text { per inch } \\
\text { ating to a temp }\end{array}$ & $\begin{array}{l}\text { e of } 0.05 \% \mathrm{Mn} \\
\text { naximum, an } \\
\text { ckness. } \\
\text { ed } 1 \% \text {. } \\
\text { on product an } \\
3 \text { is specified. } \\
\text { ementary Requ } \\
3 \text { strength lev } \\
\text { ld-drawn pipe } \\
\text { ontrol their mi } \\
\text { or double nor } \\
\text { supplied in the } \\
\text { er } 40 \text { mm in tl } \\
\text { produces an } \\
\text { guenching sha } \\
\text { of maximum } \\
\text { erature range } \\
\text { n water. Subs }\end{array}$ & $\begin{array}{l}\text { alysis when Cla } \\
\text { irement S11, th } \\
\text { els. } \\
\text { shall be heat } \\
\text { icrostructure in } \\
\text { rmalize and tem } \\
\text { e as-rolled cond } \\
\text { hickness shall } \\
\text { austenite struct } \\
\text { all be followed b } \\
\text { section thicknes } \\
\text { of } 845-980^{\circ} \mathrm{C} \text {, } \\
\text { seguently the }\end{array}$ & $\begin{array}{l}\text { ass } 2 \text { and Class } \\
\text { he Si content sl } \\
\text { treated at a te } \\
\text { accordance wi } \\
\text { nper. } \\
\text { dition. They m } \\
\text { be normalized } \\
\text { ture and then } \\
\text { by tempering at } \\
\text { holding for suff }\end{array}$ & $\begin{array}{l}\text { nitted up to a } \\
\text { the specified } \\
\text { ss } 3 \text { properties } \\
\text { shall be } 0.10 \% \\
\text { emperature of } \\
\text { vith one of the } \\
\text { tay be ordered } \\
\text { d. See ASME } \\
\text { quenched in a } \\
\text { it a subcriiical } \\
\text { fficient time to } \\
\text { tempered at a }\end{array}$ \\
\hline
\end{tabular}


Most of the data for austenitic SS and Alloy 600 have been obtained on cylindrical specimens tested under axial strain-control mode with a triangle or sawtooth waveform. For austenitic SSs, $15 \%$ of the tests in air and $9 \%$ in water were conducted under load control. The GE tests on Type 304 SS in the Dresden 1 reactor were conducted in bending with a trapezoidal waveform. Some of the data for Alloy 600 were also obtained from cantilever bending tests. In the JNUFAD data base, fatigue life of a test specimen is defined as the number of cycles for the tensile stress to drop $25 \%$ from its peak value $\left(\mathrm{N}_{25}\right)$. Fatigue lives defined by other failure criteria were normalized with Eq. 1.

The data base for austenitic SSs is composed of 453 tests in air (209 tests on 24 heats of Type 304 SS, 157 tests on 14 heats of Type 316 SS, and 87 tests on 4 heats of Type 316 NG) and 117 tests in water (41 tests for 5 heats of Type 304 and 76 for 3 heats of Type 316 NG). The tests in water are at relatively high levels of DO; 77 tests at $8 \mathrm{ppm}$ and 54 tests at $0.2 \mathrm{ppm}$ DO. Also, there are only two data points obtained at strain rates $<0.01 \% / \mathrm{s}$. Consequently, the lower bound of $0.001 \% / \mathrm{s}$ on the strain rate effect was based on the results for CSs and LASs.

The existing fatigue $\mathrm{S}-\mathrm{N}$ data base for Alloy 600 is composed of 75 tests in air and 28 tests in water. The data base is extremely limited and does not cover an adequate range of material and loading variables that might influence fatigue life. For example, the data were obtained on

Table 3. Characterization of existing $S-N$ data for several heats of austenitic stainless steel in air at various temperatures

\begin{tabular}{|c|c|c|c|c|c|c|}
\hline \multirow{2}{*}{$\begin{array}{c}\text { Temp. } \\
\left({ }^{\circ} \mathrm{C}\right)\end{array}$} & \multicolumn{2}{|c|}{ Type 304 SS } & \multicolumn{2}{|c|}{ Type 316 SS } & \multicolumn{2}{|c|}{ Type 316 NG } \\
\hline & Data & Heats & Data & Heats & Data & Heats \\
\hline 25 & 154 & 19 & 71 & 11 & 49 & 4 \\
\hline 100 & 2 & 1 & - & - & - & - \\
\hline 260 & 17 & 2 & - & - & - & - \\
\hline$\approx 290$ & 10 & 1 & 15 & 2 & 35 & 3 \\
\hline 300 & 5 & 1 & - & - & - & - \\
\hline 320 & - & - & - & - & 3 & 1 \\
\hline 400 & - & - & 16 & 1 & - & - \\
\hline$\approx 430$ & 21 & 4 & 45 & 6 & - & - \\
\hline 456 & - & - & 10 & 2 & - & - \\
\hline Total & 209 & 24 & 157 & 14 & 87 & 4 \\
\hline
\end{tabular}

Table 4. Characterization of existing $S-N$ data for several heats of austenitic stainless steel in water at various temperatures

\begin{tabular}{cccccccc}
\hline & \multicolumn{3}{c}{ Type 304 SS } & & \multicolumn{3}{c}{ Type 316 NG } \\
\cline { 2 - 4 } \cline { 6 - 8 } Temp. $\left({ }^{\circ} \mathrm{C}\right)$ & Data & DO & Heats & & Data & DO & Heats \\
\hline 260 & 11 & 0.2 & 2 & & - & - & - \\
288 & 12 & 0.2 & 2 & & 32 & 0.2 & 1 \\
& 11 & 8.0 & 1 & & 44 & 8.0 & 3 \\
300 & 7 & 8.0 & 1 & & - & - & - \\
Total & 41 & - & 5 & & 76 & - & 3 \\
\hline
\end{tabular}


Table 5. Existing fatigue $S-N$ data for several heats of Alloy 600 in air and water environments

\begin{tabular}{|c|c|c|c|c|c|c|c|c|}
\hline \multirow{2}{*}{$\begin{array}{c}\text { Heat } \\
\text { Strain Rate }(\% / \mathrm{s})\end{array}$} & \multirow{2}{*}{$\frac{\# 1}{0.1-0.6}$} & \multirow{2}{*}{$\frac{\# 2}{\mathrm{a}}$} & \multicolumn{2}{|c|}{$\# 3$} & \multicolumn{2}{|c|}{$\# 4$} & \multicolumn{2}{|c|}{$\# 5$} \\
\hline & & & $0.2-0.4$ & 10 & 0.4 & 0.004 & 0.4 & 0.004 \\
\hline Test Temp. $\left({ }^{\circ} \mathrm{C}\right)$ & \multicolumn{8}{|c|}{ Air Environment } \\
\hline 25 & 5 & 10 & 8 & 14 & 7 & - & 9 & - \\
\hline 93 & 5 & - & - & - & - & - & - & - \\
\hline 204 & 10 & - & - & - & - & - & - & - \\
\hline 316 & 7 & - & - & - & - & - & - & - \\
\hline \multicolumn{9}{|c|}{ Water Environment } \\
\hline 11288 & - & - & - & - & 9 & 3 & 11 & 5 \\
\hline
\end{tabular}

a Strain rate is not known, but is assumed to be $0.4 \% / \mathrm{s}$.

relatively few heats of material and are inadequate to establish the effect of strain rate on fatigue life in air or of temperature in water environment.

\section{Methodology}

\subsection{Modeling Choices}

In an attempt to develop a statistical model from incomplete data and where physical processes are only partially understood, care must be taken to avoid overfit of the data. Additional terms could have been added to the statistical model and used to explain more of the current data set, i.e., to make a more powerful model. However, such changes may not hold true in other data sets, and the model would typically be less robust, i.e., it would not predict new data well. In general, complexity in the model is undesirable unless it is consistent with accepted physical processes.

Managing the tradeoff between robustness and power in the model necessarily requires application of engineering judgment. Model features that would be counter to known effects are excluded. Features that are consistent with previous studies use such results as guidance, e.g., on the boundaries and saturation points for an effect, but where there are differences from previous findings, the reasons for the differences are evaluated and an appropriate set of assumptions is incorporated into the model.

\subsubsection{Functional Forms}

Different functional forms of the predictive equations (e.g., different procedures for transforming the measured variables into data used for fitting equations) were tried for several aspects of the model. Fatigue S-N data are generally expressed in terms of the Langer equation 26

$$
\varepsilon_{\mathrm{a}}=\mathrm{B}\left(\mathrm{N}_{25}\right)^{-\mathrm{b}}+\mathrm{A}
$$

where $\varepsilon_{\mathrm{a}}$ is the applied strain amplitude and $\mathrm{A}, \mathrm{B}$, and $\mathrm{b}$ are parameters of the model. Equation (2a) may be rearranged to express fatigue life $N_{25}$ in terms of strain amplitude $\varepsilon_{a}$ as

$$
\ln \left(N_{25}\right)=\left[\ln B-\ln \left(\varepsilon_{\mathbf{a}}-\mathrm{A}\right)\right] / \mathrm{b}
$$


A function that uses an exponential transformation for strain amplitude was also tried instead of the logarithmic transformation in Eq. $2 b$. In the absence of well-understood physical mechanisms, either of these functional forms is acceptable and should be interpreted as a curve that happens to fit the data. The exponential form is useful for explaining the scatter of low-strain-amplitude data, while the logarithmic form is useful for explaining mid- and highstrain-amplitude data, so the choice of form must be appropriate to the range being modeled.

\subsubsection{Grouping of Data}

To estimate the parameters, the existing data were divided into three groups: air, water with modest environmental effect, and water with significant environmental effect. For each of these groups, there are natural subgroupings in which different mechanisms operate. Because the last of these groups contains relatively fewer samples than the others, a pure least-squareerror model based on all data would underweight the influence of certain environmental conditions properly, and this could make the model less robust. The following method was adopted for optimizing the parameters of the model: the nonlinear variables (strain-amplitude thresholds) were estimated from air data only, and the effects of temperature and steel type were estimated separately from air and water data. The resulting regression analysis yielded high explanatory power without sacrificing robustness across data sets.

\subsection{Least-Squares Modeling within a Fixed Structure}

The modeling process is iterative. First, a model is tested and optimized, and then its predictions are plotted against the actual data. By examining patterns in the residual errors of different variables or data subsets, it is possible to adjust the model; this is particularly helpful when relationships are clearly nonlinear and not well understood.

The parameters of the model are commonly established through least-squares curve-fitting of the data to either Eq. $2 a$ or $2 b$. An optimization program sets the parameters so as to minimize the sum of the square of the residual errors, which are the differences between the predicted and actual values of $\varepsilon_{a}$ or $\ln \left(N_{25}\right)$. A predictive model based on least-squares fit on $\ln \left(\mathrm{N}_{25}\right)$ is biased for low $\varepsilon_{\mathrm{a}}$; in particular, runoff data cannot be included. The model also leads to probability curves that converge to a single value of threshold strain. However, the model fails to address the fact that at low $\varepsilon_{\mathrm{a}}$, most of the error in life is due to uncertainty associated with either measurement of strain or variation in threshold strain caused by material variability. On the other hand, a least-squares fit on $\varepsilon_{a}$ does not work well for higher strain amplitudes. The two kinds of models are merely transformations of each other, although the precise values of the coefficients differ.

For the present study, the two approaches were combined by minimizing the sum of squared Cartesian distances from the data points to the predicted curve. For low $\varepsilon_{\mathrm{a}}$, this is very close to optimizing the sum of squared errors in predicted $\varepsilon_{\mathrm{a}}$; at high $\varepsilon_{\mathrm{a}}$, this is very close to optimizing the sum of squared errors in predicted life; and at medium $\varepsilon_{\mathrm{a}}$, this model combines both factors. However, because the model includes many nonlinear transformations of variables and because different variables affect different parts of the data, the actual functional form and transformations are partly responsible for minimizing the square of the errors. Functional forms and transformation are chosen a priori, and no direct computational means exist for establishing them. 
To perform this optimization, it was necessary to normalize the $\mathrm{x}$ and $\mathrm{y}$ axes by assigning relative weights to be used in combining the error in life and strain amplitude because $\mathrm{x}$ and $\mathrm{y}-$ axes are not in comparable units. In this analysis, errors in strain amplitude (\%) are weighted 20 times as heavily as errors in $\ln \left(\mathrm{N}_{25}\right)$. A value of 20 was selected for two related reasons. First, this factor leads to approximately equal weighting of low and high strain amplitude data in the least-squared error computation of model coefficients. Second, when applied to the model to generate probability curves, it yielded a standard deviation on strain amplitude comparable to that obtained from the best-fit of the high cycle fatigue data to Eq. 2a. Because there is necessarily judgment applied in the selection of this value, a sensitivity analysis was performed, and it showed that the coefficients of the model do not change much for weight factors between 10 and 25. Distance from the curve was estimated as

$$
\mathrm{D}=\left\{(\mathrm{x}-\hat{\mathrm{x}})^{2}+[\mathrm{k}(\mathrm{y}-\hat{\mathrm{y}})]^{2}\right\}^{1 / 2}
$$

where $\hat{x}$ and $\hat{y}$ represent predicted values, and $\mathrm{k}=20$. Although $\mathrm{R}$-squared is only applicable for linear regression, an approximate value for combined R-squared was derived for illustrative purposes. The combined R-squared is defined as

$$
1-\left(\frac{\Sigma D^{2}}{\Sigma Z^{2}}\right)
$$

where $Z=\left\{\left(x-x^{\prime}\right)^{2}+\left[k\left(y-y^{\prime}\right)\right]^{2}\right\}^{1 / 2}$

and $x^{\prime}$ and $y^{\prime}$ represent the 25th percentile of $x$ and $y$, respectively. The 25 th percentile is selected instead of the mean because the mean values are exaggerated due to the nonlinearity of the equations, and because higher values are less influential to the model. This value is not a true R-squared, but often falls between the $\mathrm{X}$-based R-squared and the $\mathrm{y}$-based R-squared; it is considered to be a better qualitative measure of the model's predictive accuracy because it is not distorted in the way $\mathrm{x}$-based $\mathrm{R}$-squared and $\mathrm{y}$-based $\mathrm{R}$-squared measures would be.

\section{The Model}

\subsection{Carbon and Low-Alloy Steels}

The fatigue data for CS and LAS are best represented by

$$
\begin{aligned}
\ln \left(\mathrm{N}_{25}\right)= & \left(6.667-0.766 \mathrm{IW}_{\mathrm{W}}\right)-\left(1.687+0.184 \mathrm{IS}_{\mathrm{S}}\right) \ln \left(\varepsilon_{\mathrm{a}}-0.15+0.04 \mathrm{I}_{\mathrm{S}}\right) \\
& -\left(0.097-0.382 \mathrm{I}_{\mathrm{W}}\right) \mathrm{I}_{\mathrm{S}}-0.00133 \mathrm{~T}\left(1-\mathrm{I}_{\mathrm{W}}\right)+0.554 \mathrm{~S}^{*} \mathrm{~T}^{*} \mathrm{O}^{*} \dot{\varepsilon}^{*},
\end{aligned}
$$

where: $\mathrm{N}_{25}=$ the fatigue life defined as the number of cycles for the peak tensile stress to drop $25 \%$ from its initial value,

$\varepsilon_{\mathrm{a}}=$ the applied strain amplitude in $\%$,

$\mathrm{T}=$ the test temperature in ${ }^{\circ} \mathrm{C}$,

$\mathrm{IW}_{\mathrm{W}}=1$ for water and $\mathrm{O}$ for air environment,

IS $=1$ for CS and $O$ for LAS, and

$\mathrm{S}^{*}, \mathrm{~T}^{*}, \mathrm{O}^{*}$, and $\dot{\varepsilon}^{*}=$ transformed sulfur content, temperature, $\mathrm{DO}$, and strain rate,

respectively, defined as follows: 


$$
\begin{array}{ll}
\mathrm{S}^{*}=\mathrm{S} & (\mathrm{O}<\mathrm{S} \leq 0.015 \mathrm{wt} . \%) \\
\mathrm{S}^{*}=0.015 & (\mathrm{~S}>0.015 \mathrm{wt} \%) \\
\mathrm{T}^{*}=0 & \left(\mathrm{~T}<150^{\circ} \mathrm{C}\right) \\
\mathrm{T}^{*}=\mathrm{T}-150 & \left(\mathrm{~T}=150-350^{\circ} \mathrm{C}\right) \\
& \\
\mathrm{O}^{*}=0 & (\mathrm{DO}<0.05 \mathrm{ppm}) \\
\mathrm{O}^{*}=\mathrm{DO} & (0.05 \mathrm{ppm} \leq \mathrm{DO} \leq 0.5 \mathrm{ppm}) \\
\mathrm{O}^{*}=0.5 & (\mathrm{DO}>0.5 \mathrm{ppm}) \\
& \\
\dot{\varepsilon}^{*}=0 & (\dot{\varepsilon}>1 \% / \mathrm{s}) \\
\dot{\varepsilon}^{*}=\ln (\dot{\varepsilon}) & (0.001 \leq \dot{\varepsilon} \leq 1 \% / \mathrm{s}) \\
\dot{\varepsilon}^{*}=\ln (0.001) & (\dot{\varepsilon}<0.001 \% / \mathrm{s})
\end{array}
$$

Equation 5 is a modified version of the model presented earlier in NUREG/CR-6237.20 The model is recommended for predicted fatigue lives $\leq 10^{6}$ cycles. For fatigue lives between $10^{6}$ and $10^{8}$ cycles, the results should be used with caution because, in this range, the model is based on very limited data obtained on relatively few heats of material.

The following method was adopted for optimizing the parameters of the model. The constants 0.15 or 0.11 in the second term define the threshold strain amplitude or endurance limit for LAS and CS, respectively (in \% strain). These threshold values are not easily optimized with scant data at low strain amplitude and therefore were established from earlier models and from visual inspection of the data. The functional form and bounding values of the transformed parameters $\mathrm{S}^{*}, \mathrm{~T}^{*}, \mathrm{O}^{*}$, and $\dot{\varepsilon}^{*}$ were based upon experimental observations and data trends. The coefficient in second term, intercept (first and third terms), and temperature dependence (fourth term) were then established from the air data for CS and LAS. The effect of water, including the coefficient for the fifth term, were optimized using the entire data set. A combined $\mathrm{R}$-squared value of $80.1 \%$ was obtained for the analysis. The life prediction $\mathrm{R}$-squared value for this model is $83.9 \%$ and the strain amplitude prediction $\mathrm{R}$-squared value is $87.6 \%$. It would have been possible to develop a model with higher R-squared by optimizing for all data points and all parameters simultaneously. Instead, the parameters were optimized in an iterative fashion, in order to yield high explanatory power without sacrificing robustness across data sets.

Test data for heats that exhibited extreme characteristics were excluded from the analysis. Two of the 23 heats included in the data base, an A516-Gr 70 CS plate and an A508-Cl 2 alloy steel forging, show unusually high fatigue lives in air. The A516-Gr 70 steel was used by GE for the tests in the Dresden reactor. The eight tests in air show a life that is longer by nearly one order of magnitude than other CSs. The A508-Cl 2 steel was tested by two investigators; in strain-control mode by one investigator and in load-control mode by the other. The loadcontrol tests in air at RT show significantly longer lives than the tests conducted in the straincontrol mode. The different results most likely are because of the uncertainties in determining the applied strain amplitude during load-control tests; the applied strain decreases continuously during a load-control test because of strain aging of the material. The 15 load-control tests were excluded from the analysis.

The power of the model would have been increased significantly by adding an adjustment for each heat, i.e., by conducting "lot-centered" analyses so that the average residual error for each heat would be zero. However, the model would then be applicable only for those materials 

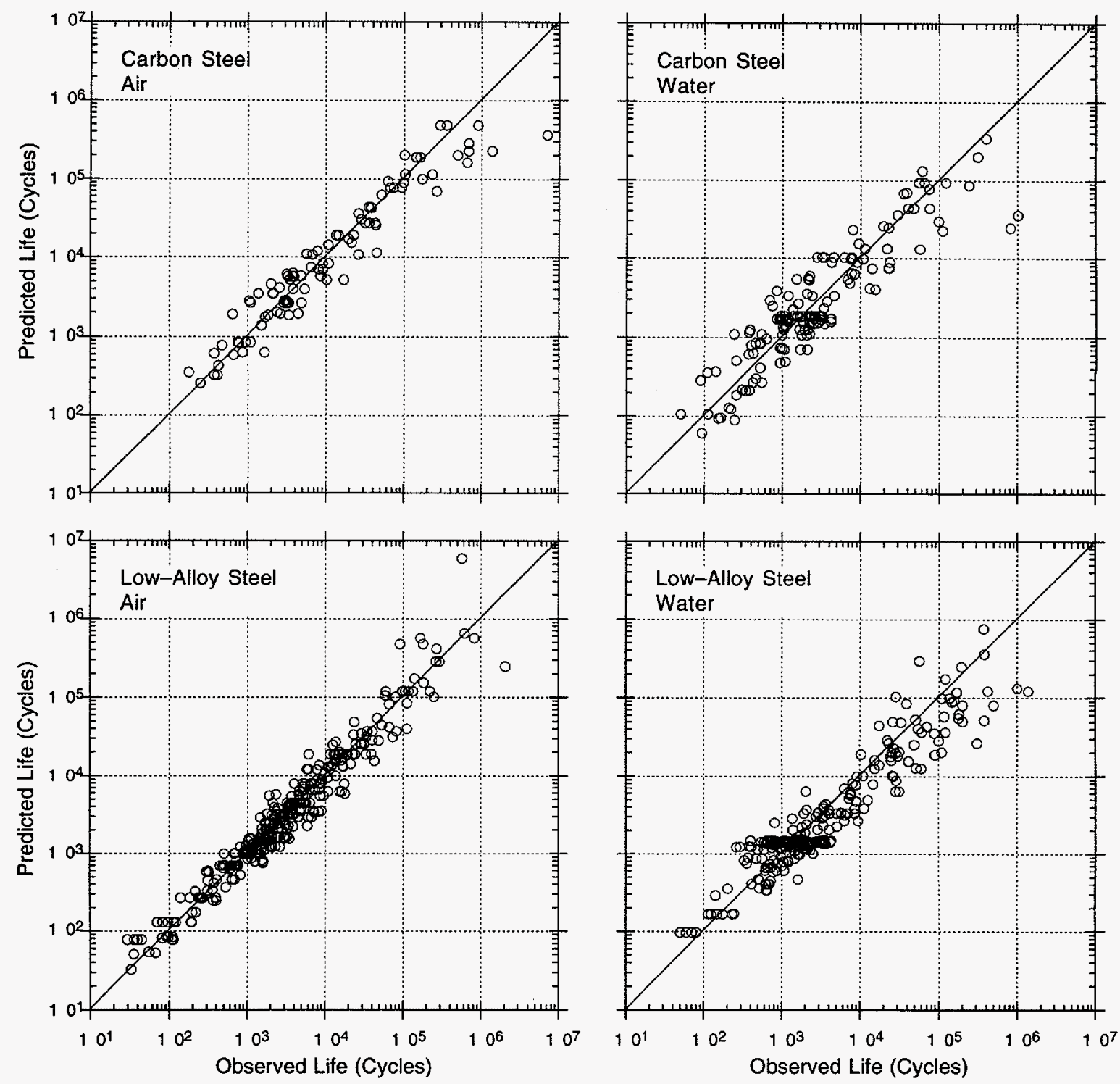

Figure 2. Experimental and predicted values of fatigue life of carbon and low-alloy steels in air and water environments

for which the lot classification is known. Such information is not available in practice. It is conceivable that with more complete data sets and comprehensive data on tensile strengths, this would be a useful feature to include in the model.

The experimental values of fatigue life of CS and LAS in air and water, and those predicted from Eq. 5, are plotted in Fig. 2. The predicted fatigue lives show good agreement with the experimental data. Examples of estimated and experimental S-N curves for CS and LAS in air are shown in Fig. 3. The mean curves used in developing the ASME Code design curve ${ }^{2}$ and the average curves of Higuchi and lida ${ }^{16}$ are also included in the figure. The results indicate that the ASME mean curve for CSs is not consistent with the experimental data; at strain amplitudes $<0.2 \%$, the mean curve predicts significantly lower fatigue lives than those observed experimentally. The estimated curve for LASs is comparable with the ASME mean curve. For both steels, Eq. 5 shows good agreement with the average curves of Higuchi and lida. 

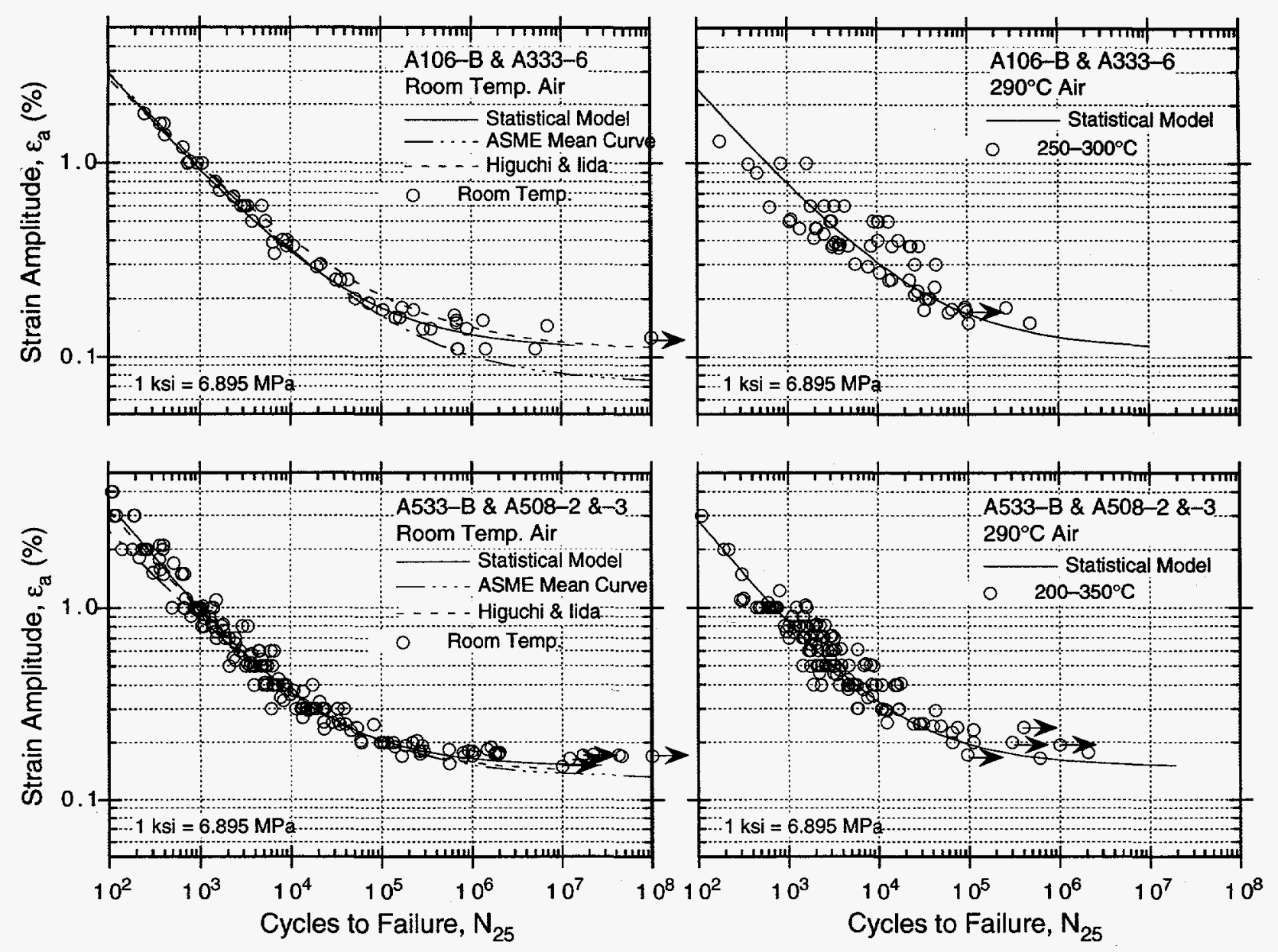

Figure 3. Fatigue $S-N$ behavior for carbon and low-alloy steels estimated from the model and determined experimentally in air at room temperature and $290^{\circ} \mathrm{C}$

The model can be used to estimate the factor by which fatigue life is changed when a specific variable is varied within the range of the experimental data base. These factors for air and water environments, determined by varying an individual variable from its base value at one end of the range to a value at the other end of the range, are given in Table 6 . The factors for water environment have been divided into two columns on the basis of whether environmental effects on fatigue life are moderate or significant. The results indicate that the effect of material and loading variables on fatigue life is insignificant in air or when environmental effects are moderate (e.g., when any one of the following conditions is true: temperature $<150^{\circ} \mathrm{C}$, $\mathrm{DO}<0.05 \mathrm{ppm}$, or strain rate $\geq 1 \% / \mathrm{s}$ ). Under these conditions, only steel type and temperature influence fatigue life. Material and loading variables such as sulfur content in the steel, temperature, DO, and strain rate, have a large effect on fatigue life in water when all of the following conditions are true: temperature $\geq 150^{\circ} \mathrm{C}$, DO $\geq 0.05 \mathrm{ppm}$, or strain rate $<1 \% / \mathrm{s}$. Under these conditions, varying any one of the four variables, e.g., temperature, DO, sulfur content, or strain rate, from their base value at one end of the range to a value at the other end of the range decreases fatigue life by a factor $\approx 70$. The values listed in the last column of Table 6 represent the maximum change in fatigue life when a specific variable is varied from its base value (second column) to the new value (third column) while the other variables are maintained at their base value. These values will be different for other base values of the variables, e.g., the effect of strain rate will be much $<73.6$ if the temperature was $200^{\circ} \mathrm{C}$ instead of $290^{\circ} \mathrm{C}$. 
Table 6. Estimates of factor by which fatigue life is changed by varying a specific variable

\begin{tabular}{|c|c|c|c|c|c|}
\hline \multirow{3}{*}{$\begin{array}{c}\text { Material or Service } \\
\text { Variable }\end{array}$} & \multirow{2}{*}{\multicolumn{2}{|c|}{$\begin{array}{l}\text { Change in } \\
\text { Variable }^{\mathrm{a}} \\
\end{array}$}} & \multicolumn{3}{|c|}{ Factor by Which Fatigue Life is Changed } \\
\hline & & & \multirow{2}{*}{$\begin{array}{c}\text { Air } \\
\text { Env. }\end{array}$} & \multicolumn{2}{|c|}{ Water Environment $\mathbf{b}$} \\
\hline & from & to & & Moderate & Significant \\
\hline Indicator $\mathrm{IW}_{\mathrm{W}}$ (LAS) & 1 & 0 & - & 2.15 & 2.15 \\
\hline Indicator $I_{W}(C S)$ & 1 & 0 & - & 1.47 & 1.47 \\
\hline Temperature $\left({ }^{\circ} \mathrm{C}\right)$ & 290 & 25 & 1.44 & 1.0 & 73.6 \\
\hline Dissolved Oxygen (ppm) & 0.50 & $<0.05$ & - & 1.0 & 73.6 \\
\hline Strain Rate $(\% / s)$ & 0.001 & 1.00 & 1.0 & 1.0 & 73.6 \\
\hline Sulfur in Steel (wt.\%) & 0.015 & 0.003 & 1.0 & 1.0 & 59.4 \\
\hline
\end{tabular}

a The change in fatigue life is estimated by varying a specific variable from its base value to the new value while the other variables are maintained at their base values. The effect of steel type is not included because it varies with strain range.

b Effect of water environment is moderate when any one of the following three conditions is not satisfied: temperature $\geq 150^{\circ} \mathrm{C}$, DO $\geq 0.05 \mathrm{ppm}$, and strain rate $<1 \% / \mathrm{s}$. Environmental effects are significant when all three conditions are satisfied.

\subsection{Austenitic Stainless Steels and Alloy 600}

The existing fatigue S-N data for austenitic SS are best represented by

$$
\ln \left(\mathrm{N}_{25}\right)=\left[6.69-1.98 \ln \left(\varepsilon_{\mathrm{a}}-0.12\right)\right]+\mathrm{I}_{\mathrm{W}}\left(0.134 \dot{\varepsilon}^{*}-0.359\right)+0.382 \mathrm{I}_{316 \mathrm{NG}}
$$

and the S-N data for Alloy 600 are best represented by

$$
\ln \left(\mathrm{N}_{25}\right)=\left[6.94-1.776 \ln \left(\varepsilon_{\mathrm{a}}-0.12\right)\right]+0.498 \mathrm{I}_{\mathrm{T}}-0.401 \mathrm{IW},
$$

where: $\mathrm{N}_{25}=$ the fatigue life defined as the number of cycles for the peak tensile stress to drop $25 \%$ from its initial value,

$\varepsilon_{\mathrm{a}}=$ the applied strain amplitude in \%,

$\mathrm{IW}=1$ for water and 0 for air environment,

$\mathrm{I}_{316 \mathrm{NG}}=1$ for Type $316 \mathrm{NG}$ SSs and is 0 otherwise,

$\mathrm{I}_{\mathrm{T}}=\mathrm{O}$ for temperatures $<150^{\circ} \mathrm{C}$ and is 1 for temperatures between 150 and $350^{\circ} \mathrm{C}$, and

$\dot{\varepsilon}^{*}=$ transformed strain rate defined as follows:

$$
\begin{array}{ll}
\dot{\varepsilon}^{*}=0 & (\dot{\varepsilon}>1 \% / \mathrm{s}) \\
\dot{\varepsilon}^{*}=\ln (\dot{\varepsilon}) & (0.001 \leq \dot{\varepsilon} \leq 1 \% / \mathrm{s}) \\
\dot{\varepsilon}^{*}=\ln (0.001) & (\dot{\varepsilon}<0.001 \% / \mathrm{s}) .
\end{array}
$$

The models for SSs and Alloy 600 are recommended for predicted fatigue lives $\leq 10^{6}$ cycles. The lower bound of $0.001 \% / \mathrm{s}$ on the strain rate effect was based on the results for CSs and LASs. A combined R-squared value of $86.7 \%$ was obtained for austenitic SSs; the life prediction Rsquared value is $81.4 \%$ and the strain amplitude prediction $\mathrm{R}$-squared value is $89.0 \%$. For Alloy 600 , a combined R-squared value of $86.4 \%$ was obtained; 92.9 for life prediction and 91.7 for strain amplitude prediction.

Note that Eq. 7 is somewhat different than the revised fatigue curve used in NUREG/CR6260 for fatigue evaluation of sample nuclear power plant components. ${ }^{27}$ The fatigue curve of 
NUREG/CR-6260 included a temperature-dependence term for life of Type 316NG SSs. Existing data for Type $316 \mathrm{NG}$ are very limited, and thus the change in life with temperature cannot be evaluated accurately. The temperature-dependence term was excluded from Eq. 7 . For Types 304 and 316 SS, estimations based on Eq. 7 or the revised curve of NUREG/CR6260 are either identical, e.g., in water at $0.001 \% / \mathrm{s}$ strain rate, or the difference is insignificant, e.g., in water at $0.1 \% / \mathrm{s}$ strain rate.

The experimental values of fatigue life in air and water and those predicted from Eqs. 7 and 8 are plotted in Fig. 4. The predicted fatigue lives show good agreement with the experimental data. The estimated S-N curves and experimental data for austenitic SSs and Alloy 600 in air at RT and $290^{\circ} \mathrm{C}$ are compared with the ASME mean curve for SSs (also used for Alloy 600 ) and the average curves of Jaske and $O^{\prime}$ Donnell. ${ }^{22}$ At temperatures of $25-450^{\circ} \mathrm{C}$, the fatigue lives of Types 304 and 316 SS in air show no dependence on temperature. On the other


Figure 4. Experimental and predicted values of fatigue life of austenitic stainless steels and Alloy 600 in air and water environments 

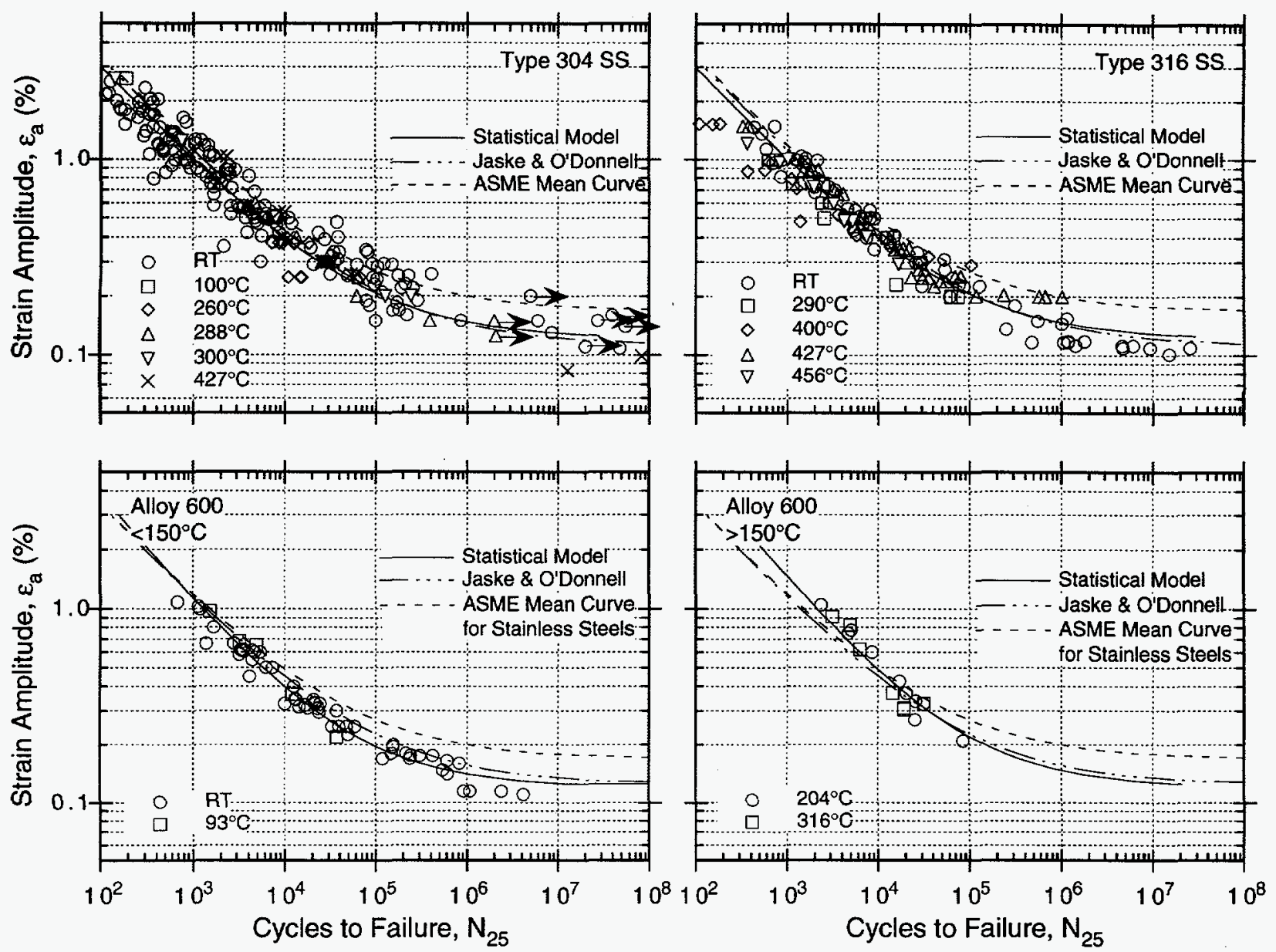

Figure 5. Fatigue $S-N$ behavior for Types 304 and 316 stainless steel and Alloy 600 estimated from the model and determined experimentally in air

hand, Alloy 600 exhibits an unusual behavior. The fatigue lives at $200-320^{\circ} \mathrm{C}$ are somewhat longer than at $<100^{\circ} \mathrm{C}$. However, these results are based on relatively few heats of material; only one heat was tested over a range of temperatures between 25 and $316^{\circ} \mathrm{C} .28$ The results also indicate that the ASME mean curve is not consistent with the experimental data for austenitic SSs or Alloy 600; at strain amplitudes $<0.5 \%$, the mean curve predicts significantly higher fatigue lives than those observed experimentally. When the S-N curve for austenitic SSs was extended to $10^{8}$ cycles, account was taken of this discrepancy, but no change was made to the curve for $<10^{6}$ cycles. For both austenitic SSs and Alloy 600 , the statistical model shows good agreement with Jaske and O'Donnell average curves; however, temperature dependence of fatigue life is ignored in Jaske and O'Donnell average curve for Alloy 600.

\section{Summary Statistics}

\subsection{Analysis of Residual Errors}

Upon completion of the modeling phase, the residual errors (in this case the Cartesian distance from the prediction curve) should not show significant patterns such as heteroskedasticity (changing variance), or a non-zero slope. The residual errors for each variable, 
grouped by steel type and environment (water or air), are plotted in Figs. 6-18. Although most data subsets and plots do not show patterns, the following were observed:

For carbon steel and low-alloy steel, data from low and medium strain ranges have higher variance than high strain range data; air data have higher variance than water data.

For stainless steel, Type 316NG data have slightly lower variance, and Type 304 data have slightly higher variance than Type 316 data. Also, air data have higher variance and low DO data may have higher variance.

For Alloy 600, water data have higher variance, and low strain rate data have mostly positive errors. The latter could be due to heat-to-heat variation (one set of data from tests conducted at $288^{\circ} \mathrm{C}$ seems to have long life).
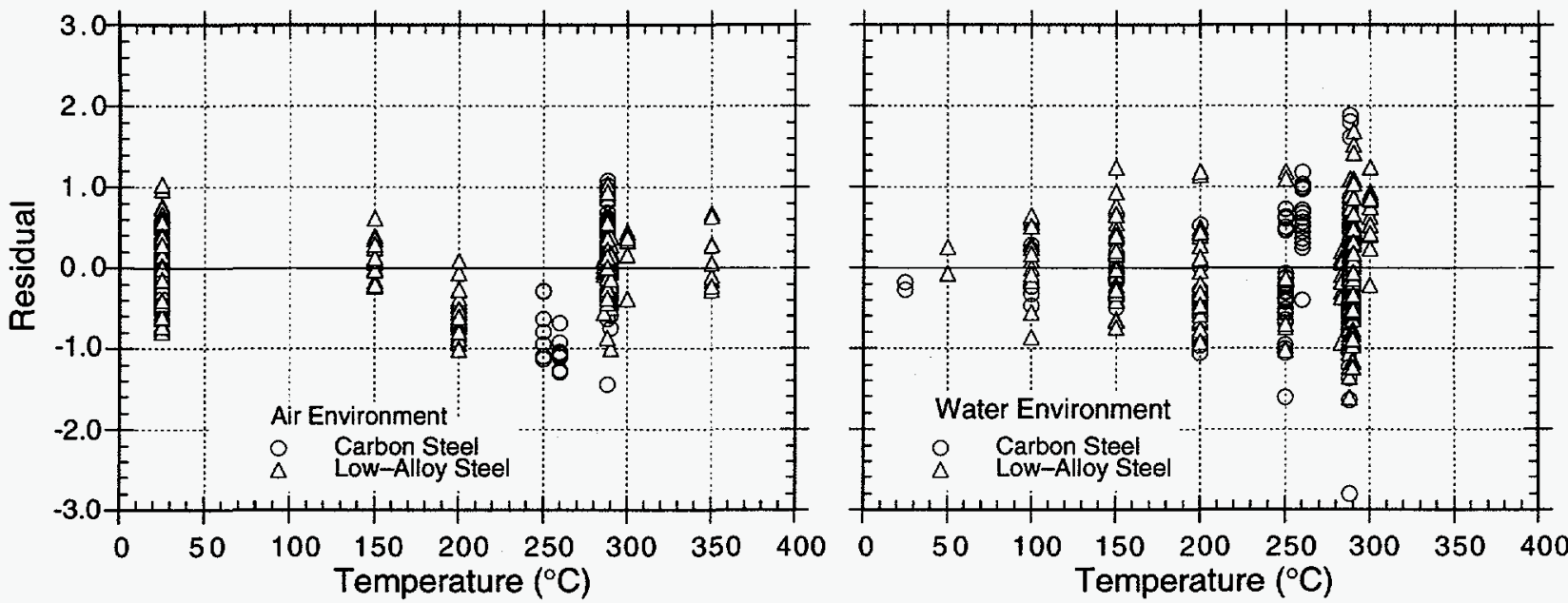

Figure 6. Residual error for carbon and low-alloy steels as a function of test temperature
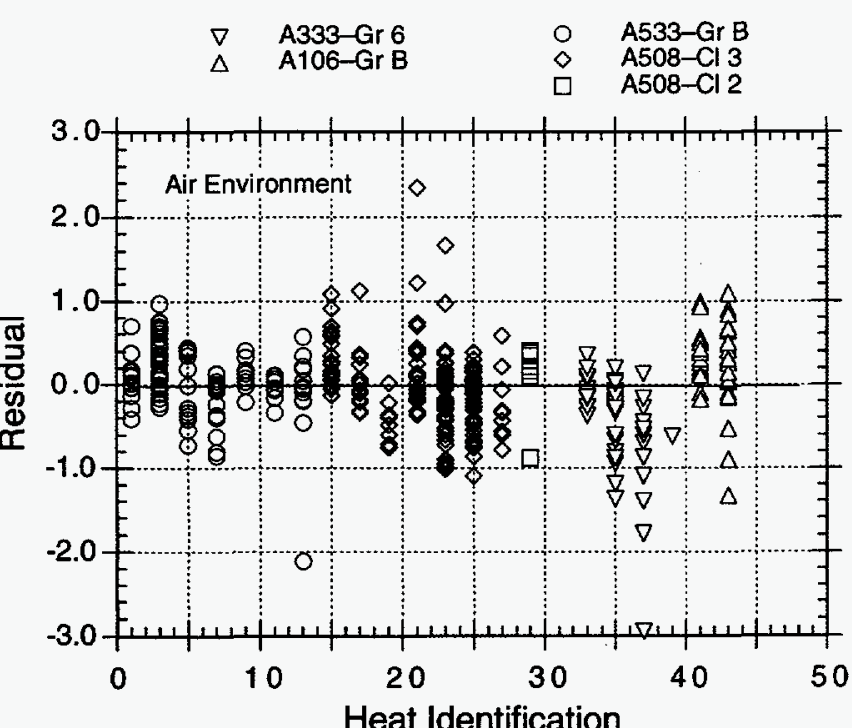

$\begin{array}{cc}+ & \text { A508-Cl 1 } \\ \nabla & \text { A333-Gr 6 } \\ \triangle & \text { A106-Gr B }\end{array}$

$\times \quad$ A516-Gr 70

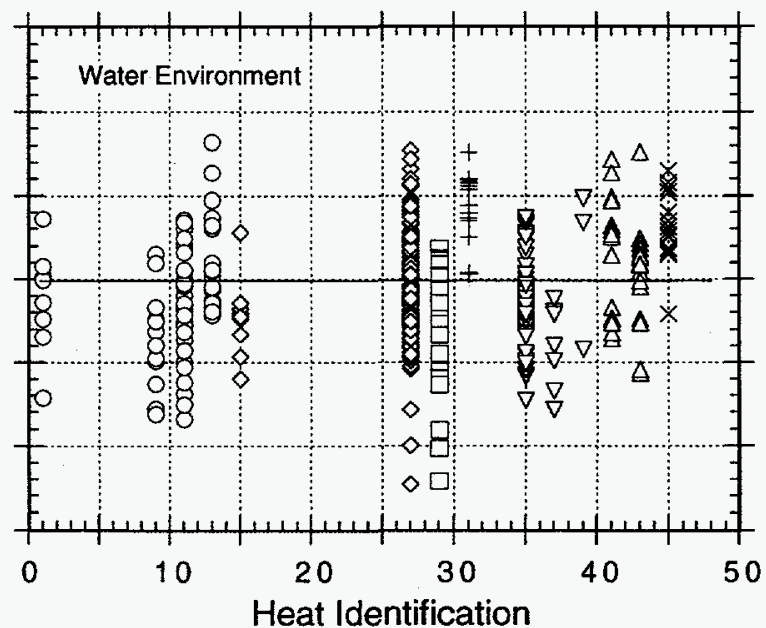

Figure 7. Residual error for carbon and low-alloy steels plotted as a function of material heat 

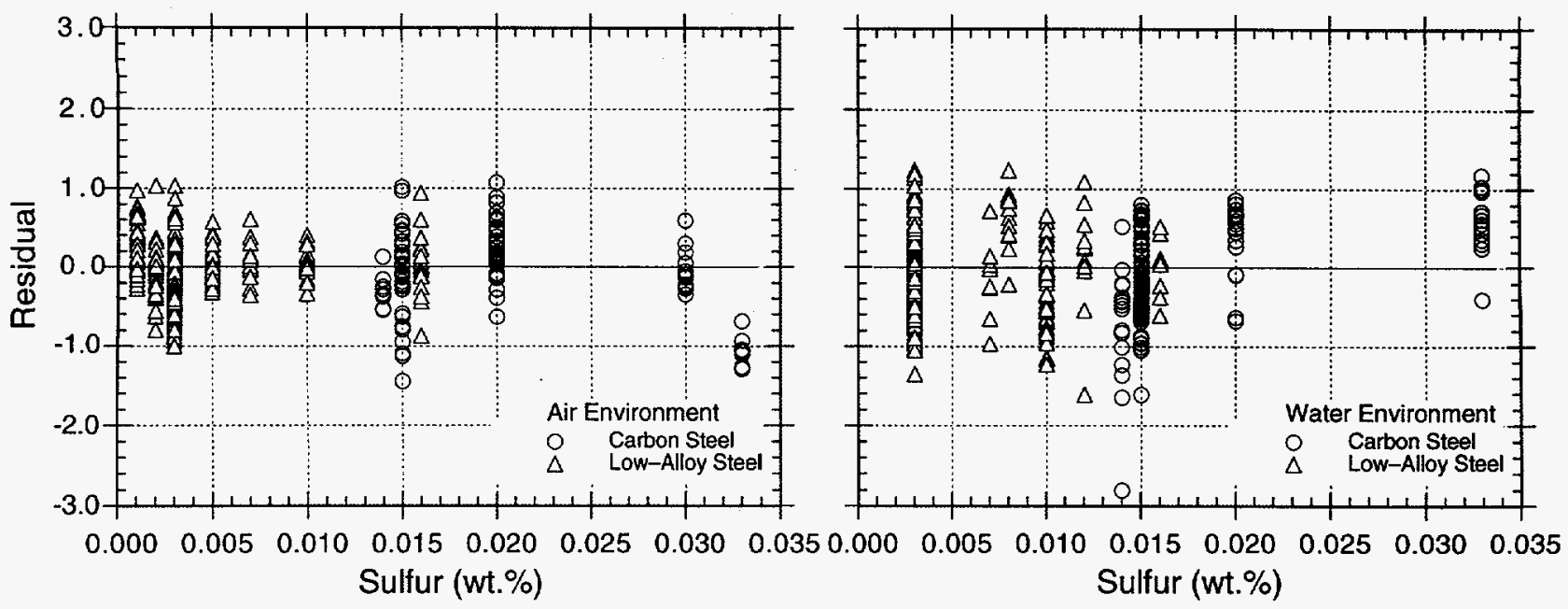

Figure 8. Residual error for carbon and low-alloy steels as a function of sulfur content of the steel
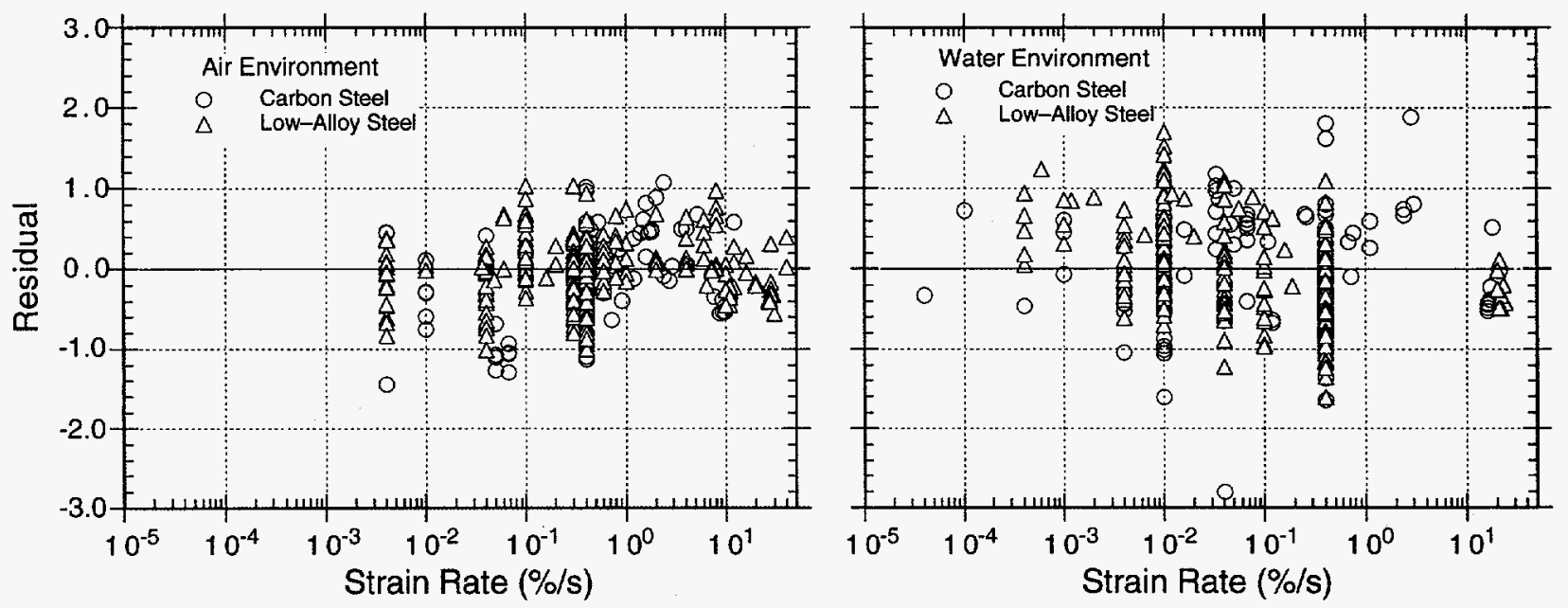

Figure 9. Residual error for carbon and low-alloy steels as a function of loading strain rate
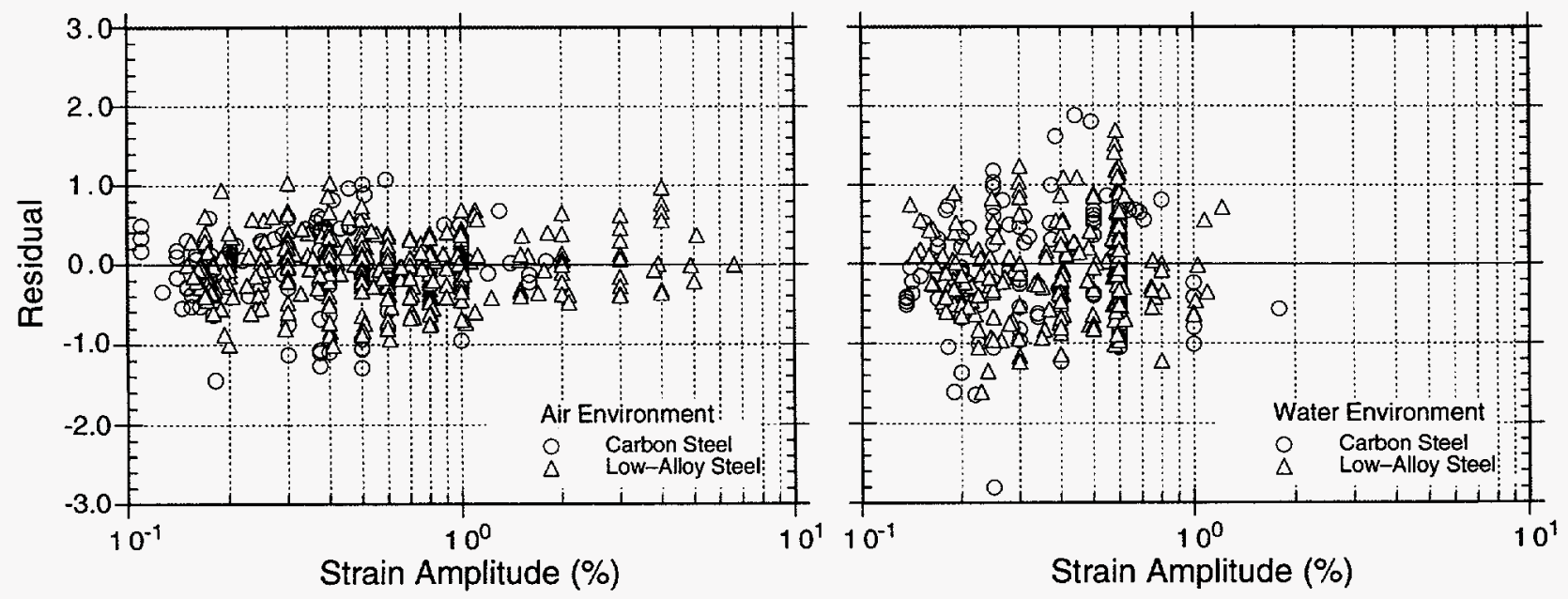

Figure 10. Residual error for carbon and low-alloy steels as a function of applied strain amplitude 

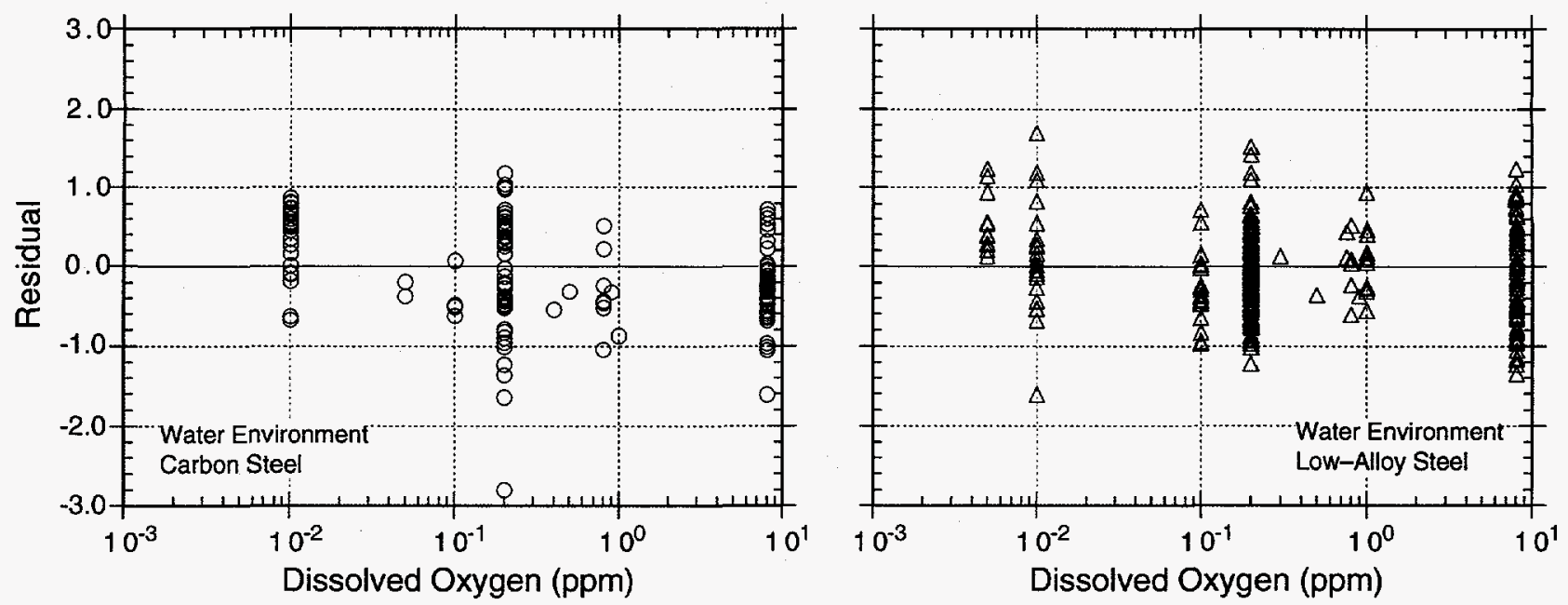

Figure 11. Residual error for carbon and low-alloy steels as a function of dissolved oxygen in water
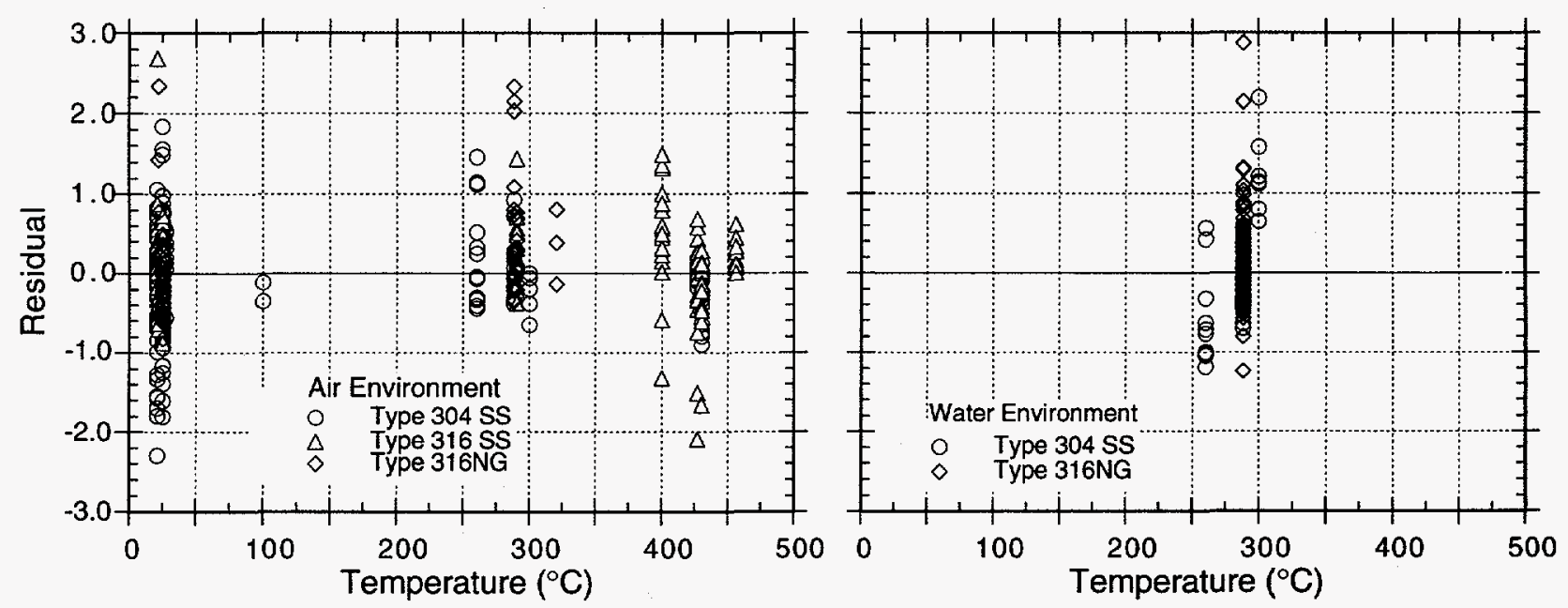

Figure 12. Residual error for austenitic stainless steels as a function of test temperature
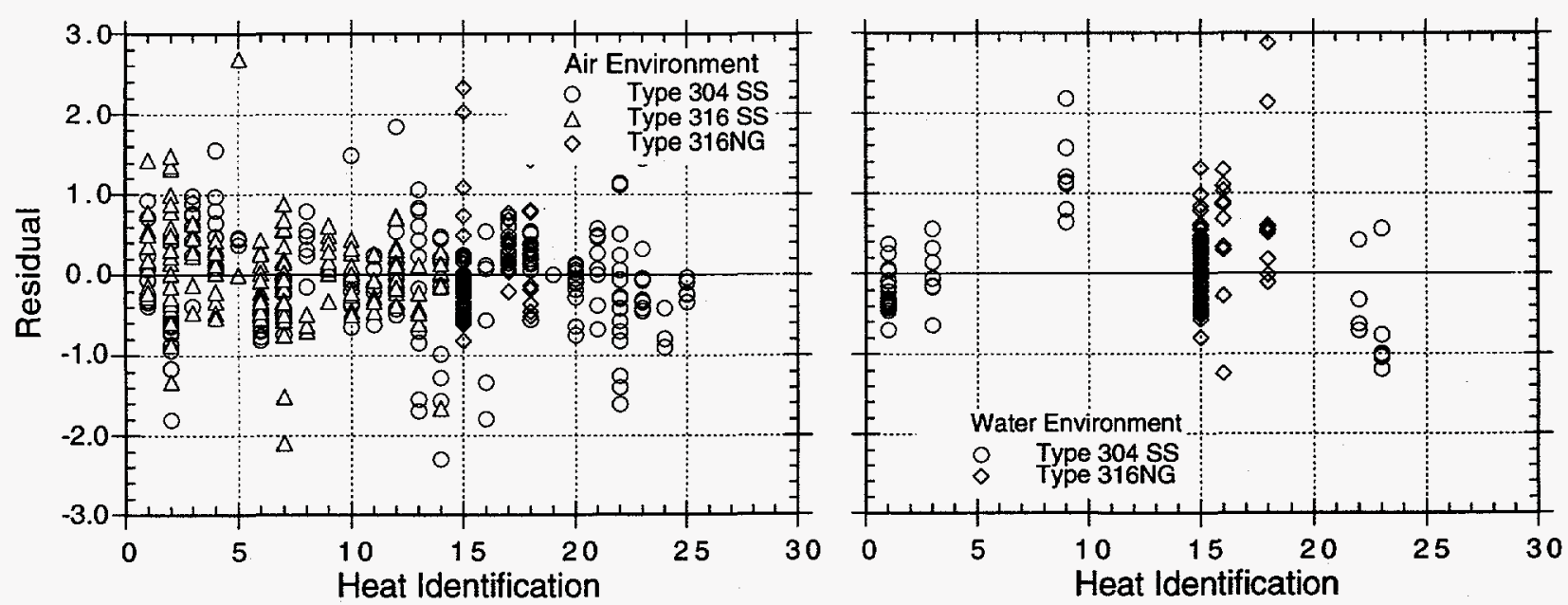

Figure 13. Residual error for austenitic stainless steels plotted as a function of material heat 

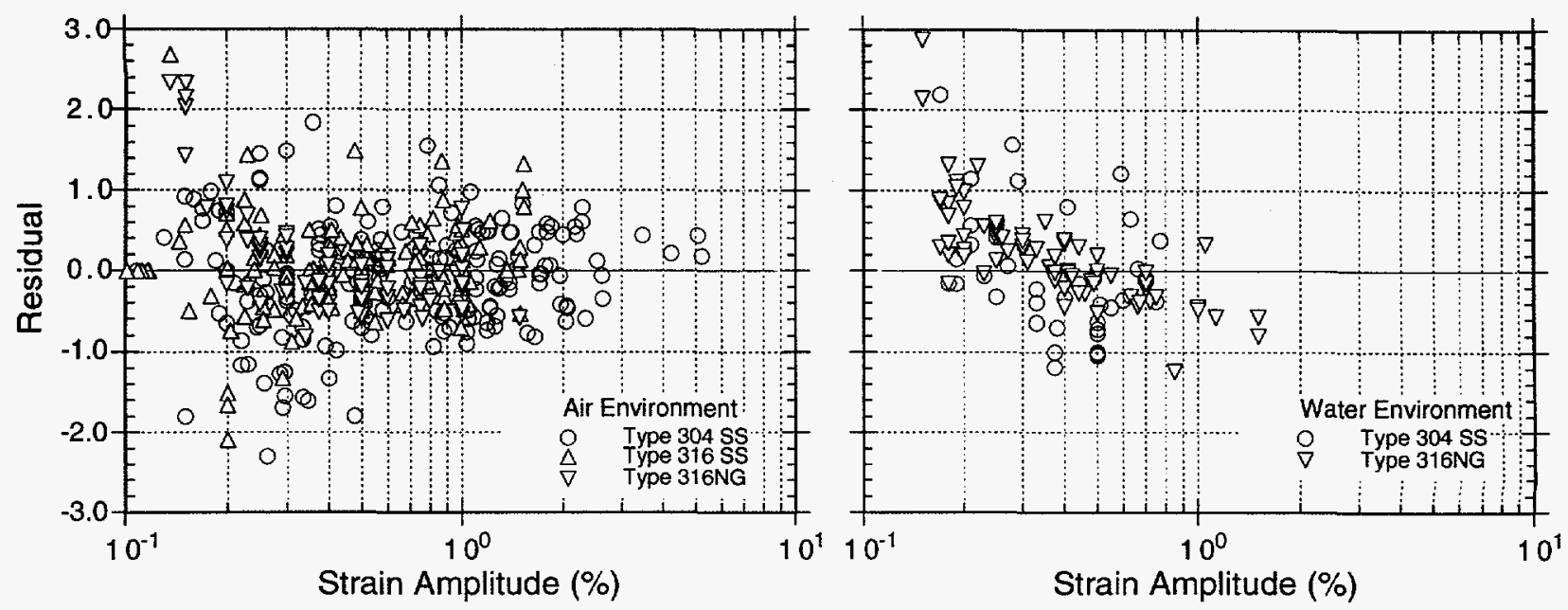

Figure 14. Residual error for austenitic stainless steels as a function of applied strain amplitude
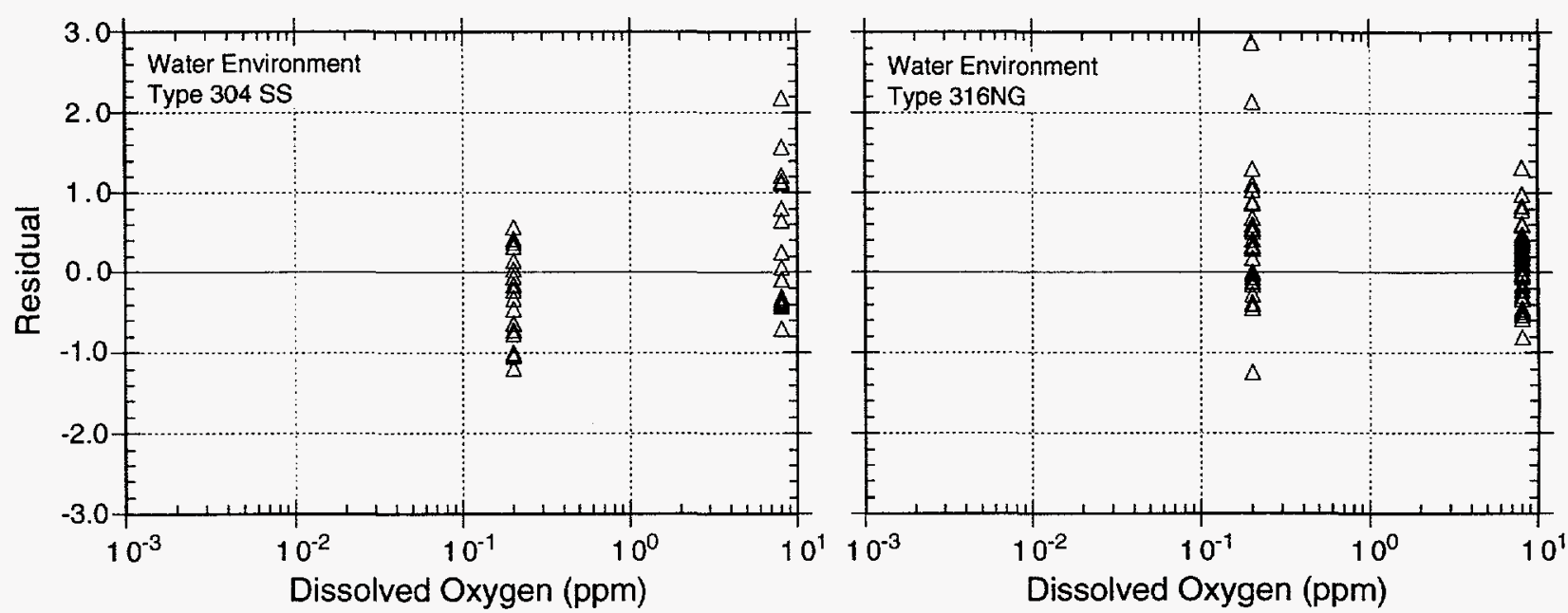

Figure 15. Residual error for austenitic stainless steels as a function of dissolved oxygen in water
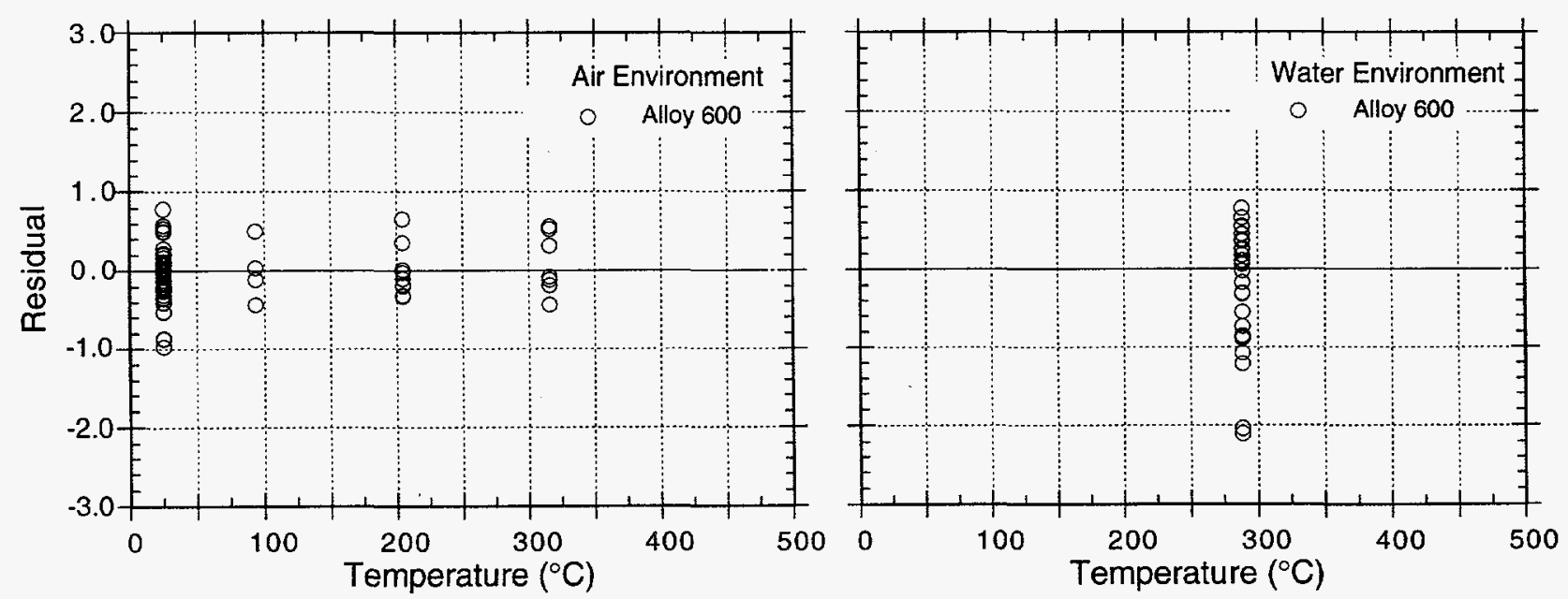

Figure 16. Residual error for Alloy 600 as a function of test temperature 

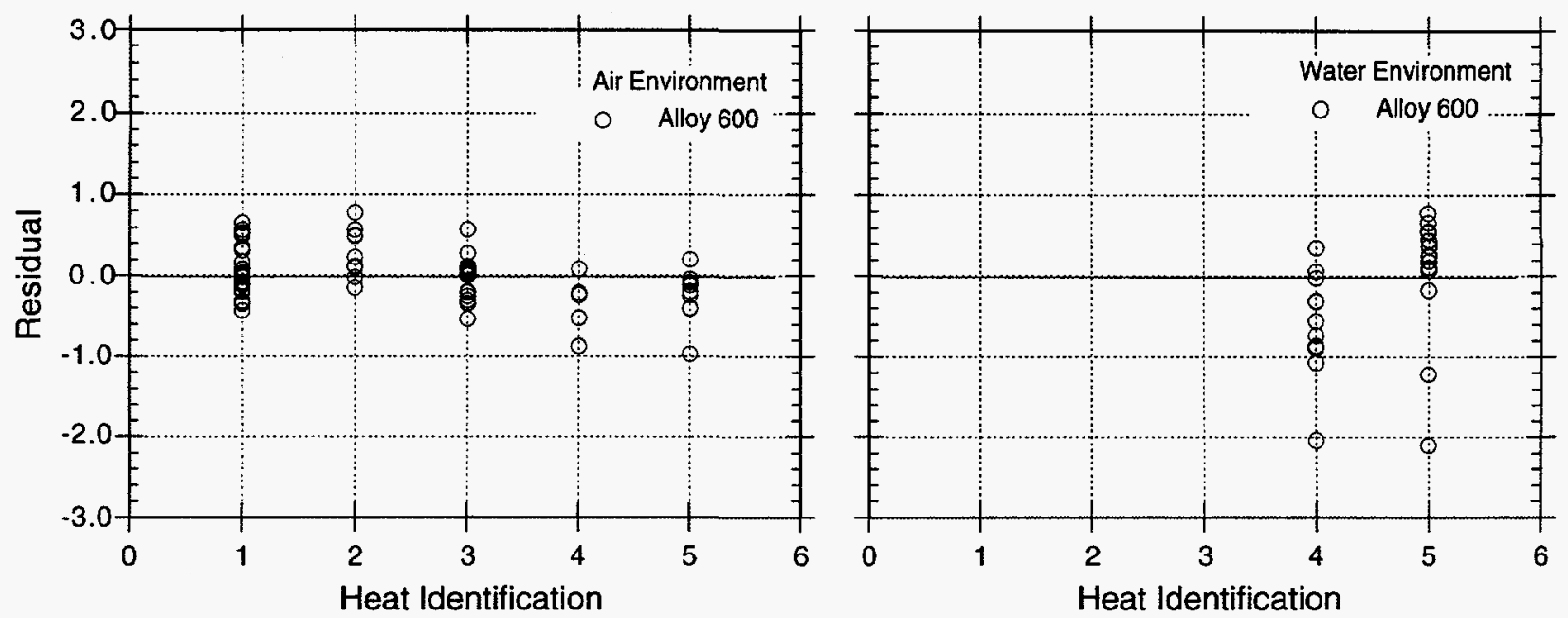

Figure 17. Residual error for Alloy 600 plotted as a function of material heat
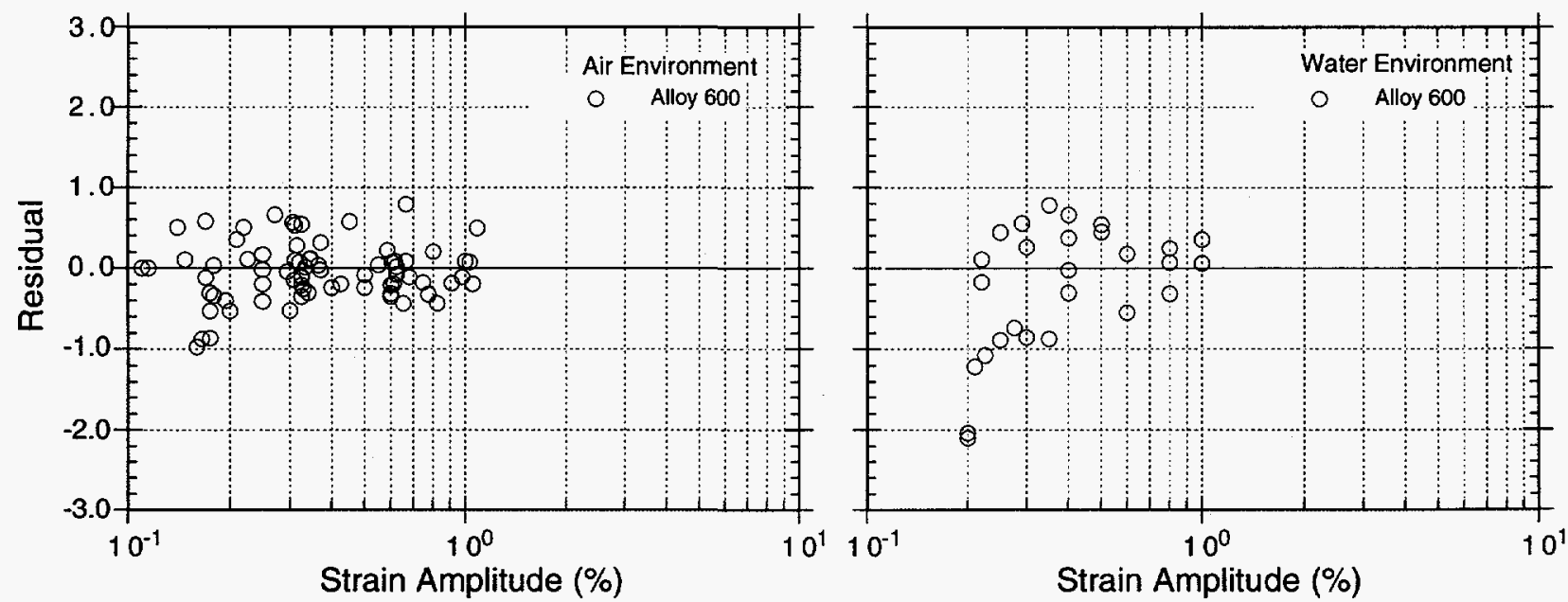

Figure 18. Residual error for Alloy 600 as a function of applied strain amplitude

High variance in general tends to be associated with longer lives and lower strain amplitudes. In all of the cases where variance seems higher in one region of the data than another, the difference is $\approx 50 \%$. Biases seem to be traceable to heat-to-heat variation.

\subsection{Statistical Significance of Parameter Values}

Errors are associated with estimates of parameter values. These errors are a function of the importance and strength of the effects in question, as well as of the amount and variation of the data used to estimate them. The standard error and t-statistic for the best-fit values of the coefficients for various parameters in the statistical models are presented in Tables 7 and 8 for CSs and LASs and austenitic SSs and Alloy 600, respectively. Confidence intervals for the parameter values are based on the specific data sets used to determine them, rather than on the entire data set. The estimates of error were determined by fixing nonlinear aspects and taking the linear regression output for each data set for a model to predict $\ln \left(\mathrm{N}_{25}\right)$. These errors were then applied to the parameters obtained in the Cartesian distance squared errorminimizing model; as for any nonlinear regression, the resulting confidence intervals and 
Table 7. Standard error and t-statistic for the coefficients of various parameters in the statistical model for carbon and low-alloy steels

\begin{tabular}{lcccccc}
\hline & & Standard & $\mathrm{t}-$ & Lower & Upper & \\
Variable & Coefficient & Error & Statistic & $95 \%$ & $95 \%$ & Factor \\
\hline Intercept (LAS) & 6.667 & 0.0578 & 115.3 & 6.552 & 6.782 & 1.122 \\
Intercept (CS) & 6.570 & 0.0933 & 70.4 & 6.385 & 6.755 & 1.203 \\
Intercept (LAS Water) & -0.766 & 0.0700 & -10.9 & -0.905 & -0.627 & 1.149 \\
Intercept (CS Water) & -0.384 & 0.1130 & -3.4 & -0.608 & -0.160 & 1.251 \\
Strain Amplitude (LAS) & -1.687 & 0.0218 & -77.5 & -1.733 & -1.647 & 1.042 \\
Strain Amplitude (CS) & -1.871 & 0.0407 & -45.9 & -1.951 & -1.789 & 1.084 \\
TSOR & 0.554 & 0.0350 & 15.8 & 0.485 & 0.623 & 1.708 \\
Temperature & -0.00133 & 0.00028 & -4.75 & -0.00189 & -0.00077 & 1.183 \\
\hline
\end{tabular}

Table 8. Standard error and t-statistic for the coefficients of various parameters in the statistical models for austenitic stainless steels and for Alloy 600

\begin{tabular}{|c|c|c|c|c|c|c|}
\hline Variable & Coefficient & $\begin{array}{c}\text { Standard } \\
\text { Error }\end{array}$ & $\begin{array}{c}\mathrm{t}- \\
\text { Statistic }\end{array}$ & $\begin{array}{c}\text { Lower } \\
95 \% \\
\end{array}$ & $\begin{array}{c}\text { Upper } \\
95 \%\end{array}$ & Factor \\
\hline \multicolumn{7}{|c|}{ Austenitic Stainless Steel } \\
\hline Intercept & 6.690 & 0.0764 & 87.6 & 6.538 & 6.841 & 1.164 \\
\hline Strain Amplitude & -1.980 & 0.0456 & -43.4 & -2.070 & -1.890 & 1.095 \\
\hline Intercept (Water) & -0.359 & 0.1170 & -3.1 & -0.591 & -0.127 & 1.261 \\
\hline Strain Rate (Water) & 0.134 & 0.0470 & 2.9 & 0.041 & 0.227 & 1.702 \\
\hline Type 316 NG & 0.382 & 0.1430 & 2.7 & 0.098 & 0.666 & 1.328 \\
\hline \multicolumn{7}{|l|}{ Alloy 600} \\
\hline Intercept & 6.940 & 0.0799 & 86.9 & 6.782 & 7.098 & 1.172 \\
\hline Strain Amplitude & -1.776 & 0.0455 & -39.0 & -1.866 & -1.686 & 1.094 \\
\hline Temperature & 0.498 & 0.1030 & 4.8 & 0.294 & 0.702 & 1.227 \\
\hline Intercept (Water) & -0.401 & 0.0901 & -4.5 & -0.580 & -0.222 & 1.196 \\
\hline
\end{tabular}

$\mathrm{t}$-statistics are not exact. The t-statistic for each variable is the number of standard errors from 0 to the estimated value of the coefficients; it is an indication of the statistical significance of that parameter of the model. Values of $t$-statistic $>2.5$ provide convincing evidence of the statistical significance of the variable. These results are conditional on the assumptions about functional form and nonlinear or nonuniform aspects of the model; confidence in the functional form is established by the better performance of one model over another.

The 95\% lower bound for the estimate of each coefficient (fifth column of Tables 7 and 8 ) is approximately 2 standard errors below its mean estimate, and the 95\% upper bound (sixth column) is approximately 2 standard errors above the mean estimate. The $99 \%$ lower and upper bounds are approximately 2.5 standard errors from the mean estimate. The last column gives the factor by which predicted life would change if either the lower or upper $95 \%$ bound on the corresponding coefficient, whichever would lead to a shorter life, were assumed instead of its mean value. An example of how to interpret this table is, for CS or LAS, if the coefficient for temperature is at its mean estimated value of -0.00133 , predicted life would be 1.183 times greater than if the coefficient for temperature is at its $95 \%$ lower bound value of -0.00189 . 
Table 9. Results of normality tests for carbon and low-alloy steels, austenitic stainless steels, and Alloy 600

\begin{tabular}{lccc}
\hline & Carbon \& Low-Alloy & & Austenitic \\
& Steels & Alloy 600 & Stainless Steels \\
\hline Mean & -0.14 & -0.03 & -0.01 \\
Variance & 0.26 & 0.13 & 0.27 \\
Skewness & -0.055 & -0.18 & -0.215 \\
Kurtosis & 3.16 & 3.07 & 4.52 \\
Categories & 20 & 8 & 15 \\
Chi-Squared & 0.181 & 0.320 & 1.50 \\
Kolmogorov-Smirnov & 0.029 & 0.074 & 0.036 \\
Anderson-Darling & 0.926 & 0.48 & 1.20 \\
\hline
\end{tabular}

\subsection{Normality Tests}

For each type of material, the errors (expressed as Cartesian distance from the curve) were fitted (using best-fit software) to several candidate distributions: normal, Weibull, log normal, and beta. For the carbon steel data, one data point was removed from this analysis because it was 2 standard deviations lower than any other data point. The number of categories in analyzing each type of steel was chosen to be roughly proportional to the size of the data set. The results are given in Table 9.

For each test and for each steel type, the normal distribution was the best fit among the candidate distributions. A true normal distribution has a mean of 0 , skewness of 0 , and kurtosis of 3. The statistics above, as well as visual inspection of the histograms for these data, suggest that the distances are approximately normal and reasonably well behaved at the extremes, but slightly more peaked near 0 and with slightly more weight than normal on the tails for events with probability well below $1 \%$. This is consistent with the observation that variances are slightly greater for low strain amplitudes than high strain amplitudes.

For CS and LAS data, the chi-squared values (using 10 classes) imply that the normal distribution cannot be rejected at alpha $=0.995$. Other distributions, e.g., log normal, Weibull, or beta, cannot be rejected either. When 20 classes are used, the chi-squared values are normal: 0.18 , Weibull: $0.44, \log$ normal: 4.76 , beta: 20.2 . The Weibull and normal distributions still cannot be rejected at alpha $=0.999$, while the beta distribution is rejected at alpha $=0.1$. Although the log normal distribution is not as good a fit as normal, it cannot be rejected at this level either. The normal distribution ranks first based on the three goodness-of-fit tests used (chi-squared, Kolmogorov-Smirnov, Anderson-Darling). Beyond 20 classes, there are too few expected occurrences in each class $(<5$ for some classes) to interpret the chi-squared values as rejecting or not rejecting hypothetical distributions.

In summary, the data are not sufficient to distinguish between normal and Weibull distributions. Neither perfectly reflects the true distribution. The normal distribution is used in the model instead of the Weibull distribution primarily because it is more common. If needed, a more precise characterization of the residuals may be derived by examining subsets of the data that are expected to follow different distributions. The existing data in these smaller groups are inadequate to establish the exact generating distributions. 
Table 10. Standard deviation of distance from mean $S-N$ curve for the different materials

\begin{tabular}{lccc}
\hline & Carbon and & Austenitic & \\
& Low-Alloy Steel & Stainless Steel & Alloy 600 \\
\hline Standard Deviation on Life $\left(\mathrm{N}_{25}\right)$ & 0.520 & 0.520 & 0.420 \\
Standard Deviation on Strain Amplitude $\left(\varepsilon_{\mathrm{a}}\right)$ & 0.026 & 0.026 & 0.021 \\
\hline
\end{tabular}

\section{Probability Distributions of Fatigue Life}

The average distance of data points from the mean curve does not vary much across different environmental conditions, except for steel types. To develop a probability distribution on life, we start with the assumption that there are two sources of prediction error, viz., error in the estimated difference between strain amplitude and threshold strain caused by both measurement error and material variability that leads to variation in the threshold strain, and scatter in fatigue life due to uncertainty in test and material conditions or other unexplained variation. In the limit, the standard deviation of distance from the mean curve at high strain amplitudes is equal to the standard deviation of the scatter in fatigue life. At low strain amplitude, the standard deviation of distance from the mean curve is equal to the standard deviation of the error in strain amplitude times the weighting factor of 20 (a weight factor of 20 was selected because it yielded a standard deviation on strain amplitude comparable to that obtained from the best-fit of the high cycle fatigue data to Eq. 2a). The standard deviations on life and on strain amplitude for the three materials are given in Table 10. These results can be combined with Eqs. 5-9 to estimate the probability distribution on life for smooth test specimens. The $x$ th percentile of the probability distribution on life $\mathrm{N}_{25}[\mathrm{x}]$ for CSs and LAS test specimens is

$$
\begin{aligned}
\ln \left[N_{25}(\mathrm{x})\right] & =(6.667-0.766 \mathrm{IW})-\left(0.097-0.382 \mathrm{IW}_{\mathrm{W}}\right) \mathrm{I}_{\mathrm{S}}+0.52 \mathrm{~F}^{-1}[\mathrm{x}] \\
& -\left(1.687+0.184 \mathrm{IS}_{\mathrm{S}}\right) \ln \left(\varepsilon_{\mathrm{a}}-0.15+0.04 \mathrm{I}_{\mathrm{S}}+0.026 \mathrm{~F}^{-1}[1-\mathrm{x}]\right) \\
& \left.-0.00133 \mathrm{~T}\left(1-\mathrm{IW}_{\mathrm{W}}\right)+0.554 \mathrm{~S}^{*} \mathrm{~T}^{*} \mathrm{O}^{*} \dot{\varepsilon}^{*}\right),
\end{aligned}
$$

for austenitic SSs it is

$$
\begin{aligned}
\ln \left[N_{25}(x)\right] & =6.69+0.52 F^{-1}[x]-1.98 \ln \left(\varepsilon_{a}-0.12+0.026 F^{-1}[1-x]\right) \\
& +\operatorname{IW}\left(0.134 \dot{\varepsilon}^{*}-0.359\right)+0.382 I_{316 N G},
\end{aligned}
$$

and for Alloy 600 it is

$$
\begin{aligned}
\ln \left[N_{25}(\mathrm{x})\right] & =6.94+0.52 \mathrm{~F}^{-1}[\mathrm{x}]-1.776 \ln \left(\varepsilon_{\mathrm{a}}-0.12+0.026 \mathrm{~F}^{-1}[1-\mathrm{x}]\right) \\
& +0.498 \mathrm{I}_{\mathrm{T}}-0.401 \mathrm{I}_{\mathrm{W}}
\end{aligned}
$$

where $\mathrm{F}^{-1}[\mathrm{x}]$ and $\mathrm{F}^{-1}[1-\mathrm{x}]$ are the inverse of the standard normal cumulative distribution function. The coefficients of distribution functions $\mathrm{F}^{-1}[\mathrm{x}]$ and $\mathrm{F}^{-1}[1-\mathrm{x}]$ in Eqs. 10-12 represent the standard deviation on life and strain amplitude, respectively. The values of 0.52 and 0.026 are also used in Eq. 12 for Alloy 600 because the observed value of 0.42 is based on a very limited data base (the data were obtained on only five heats of material) and is not representative of the uncertainties associated with material variability.

This technique leads to probability curves that are farther from the mean curve (by a factor of up to 1.4 ) in the middle range of strain amplitudes (i.e., for $\varepsilon_{\mathrm{a}}=0.2-0.4 \%$ ) than at low and 
high strain amplitudes. For example, the xth percentile probability curve implies a greater average squared distance from the mean curve than the distance actually derived from the data. An examination of the residual errors is consistent with this shape of curve, but it is not clear whether the technique overestimates uncertainty in the middle while being unbiased at the extremes, or has a slight bias for the entire range of strain amplitudes. Other less-conservative techniques that could be used instead would be to assume constant distances between probability curves and the mean curve (this approach is more computationally complex), or to apply a factor of 0.8 to the standard deviations for $\varepsilon_{a}$ or $\ln \left(\mathrm{N}_{25}\right)$. With additional data, it might be possible to choose one of these techniques. Furthermore, the standard deviation of 0.026 on strain amplitude may be a conservative value. A realistic value for the standard deviation on strain may be obtained from the threshold strains for specific heats of material. The existing data are inadequate for such an analysis because (a) not enough heats of materials are included in the data base, and (b) there are very few high-cycle fatigue data for accurate estimations of threshold strains for specific materials.

The estimated probability curves for the fatigue life of carbon and low-alloy ferritic steels, austenitic SSs, and Alloy 600 in air and simulated PWR water are shown in Figs. 19-23. For
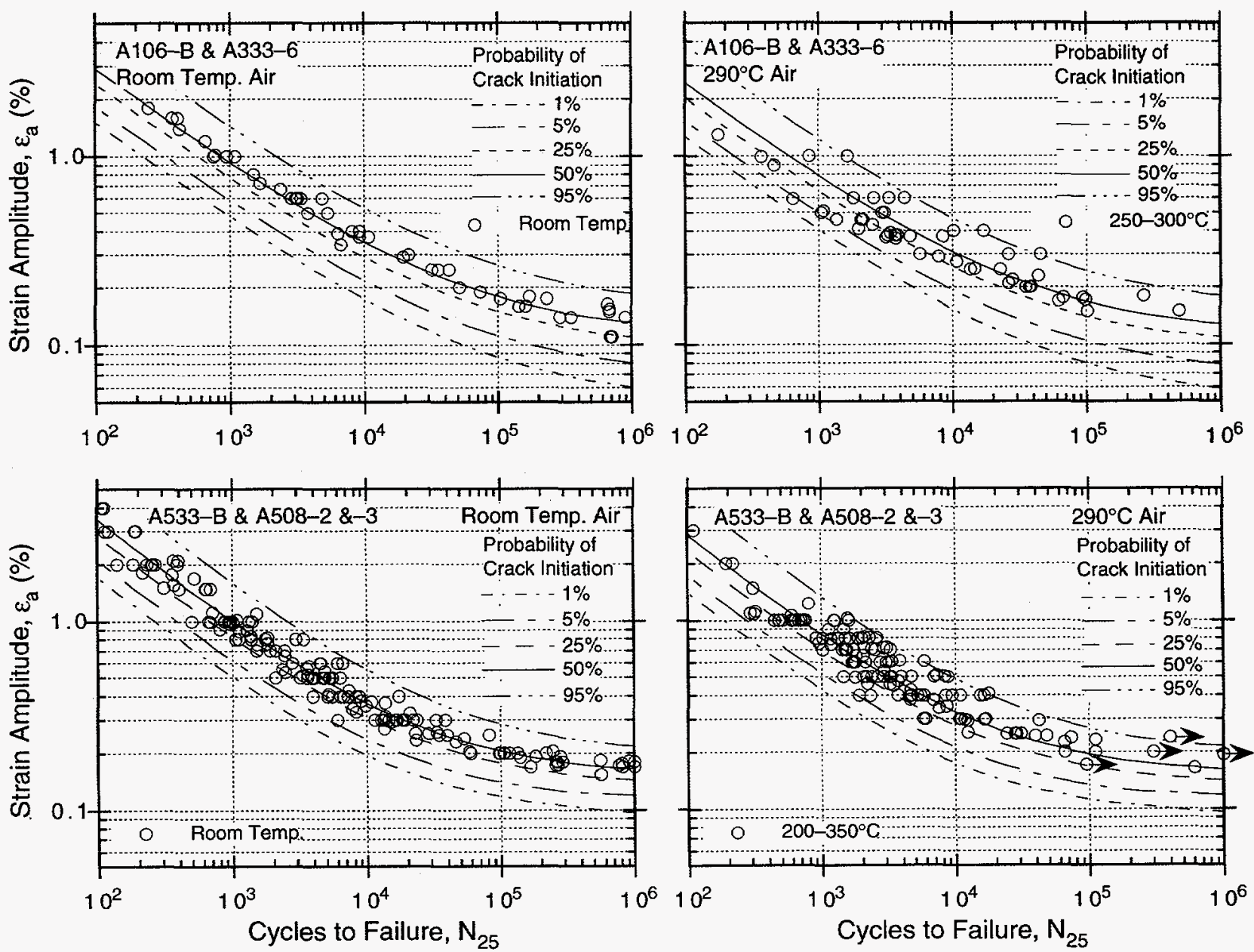

Figure 19. Experimental data and probability of fatigue crack initiation in carbon and low-alloy steel test specimens in air at room temperature and $290^{\circ}$ 

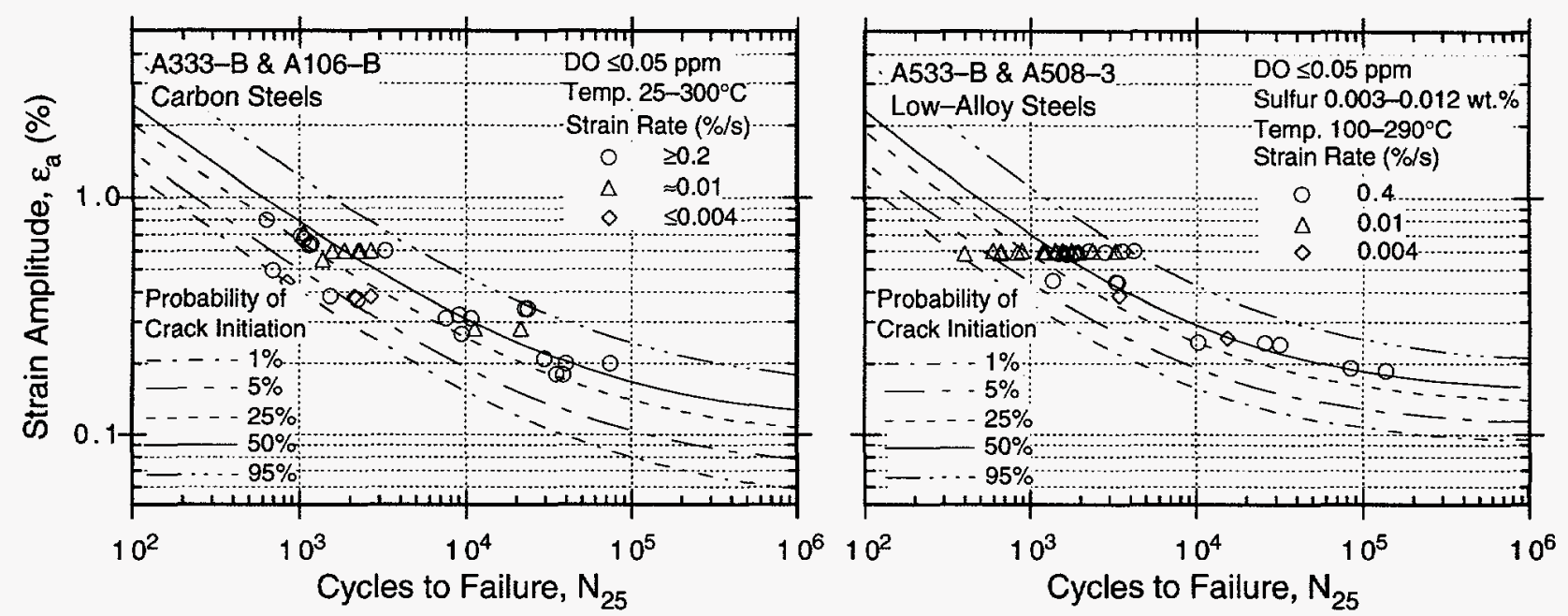

Figure 20. Experimental data and probability of fatigue crack initiation in carbon and low-alloy steel test specimens in PWR environment
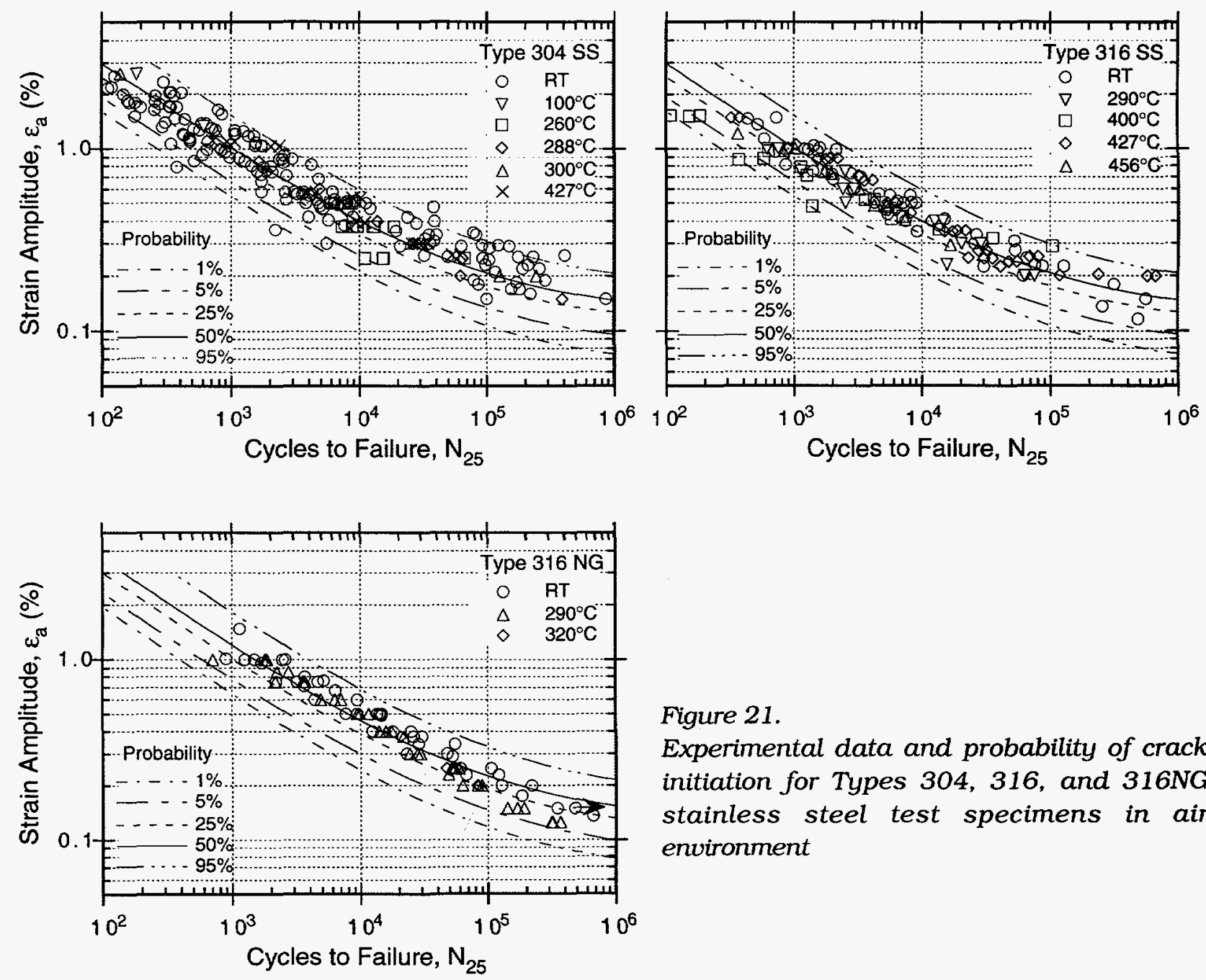

Figure 21.

Experimental data and probability of crack initiation for Types 304, 316, and 316NG stainless steel test specimens in air environment 

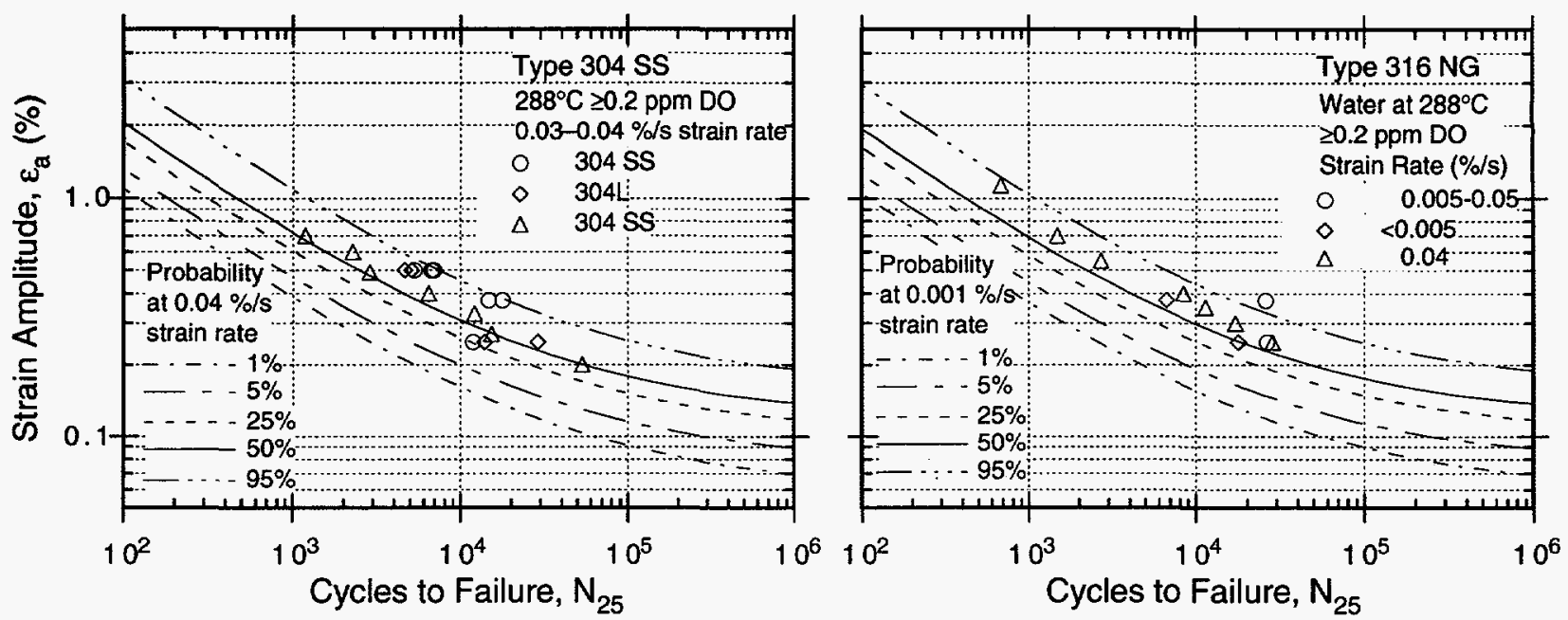

Figure 22. Experimental data and probability of crack initiation for Types 304 and 316NG stainless steel test specimens in water environment
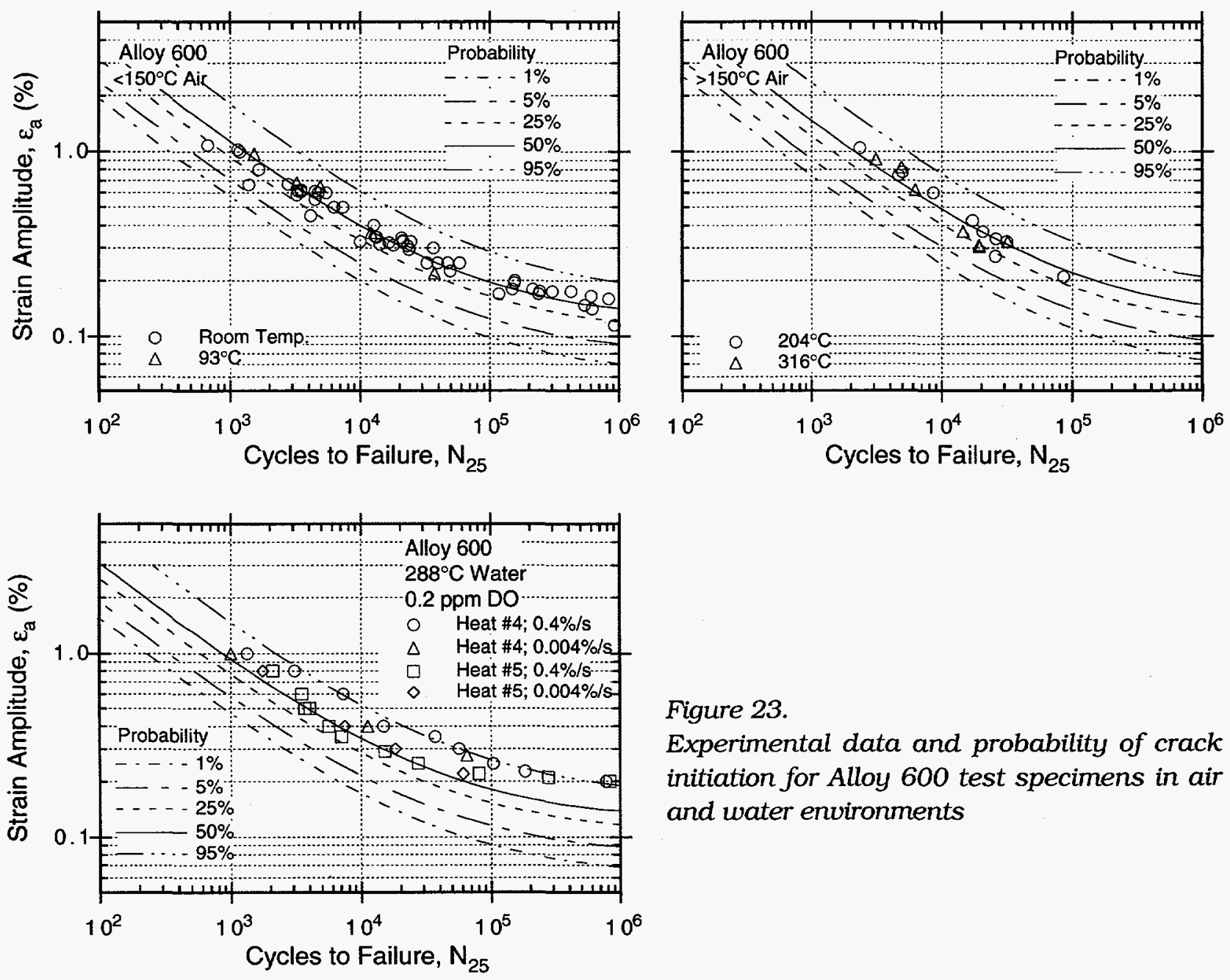

Figure 23.

Experimental data and probability of crack initiation for Alloy 600 test specimens in air and water environments 
PWRs, the primary water chemistry guidelines ${ }^{29}$ specify control of DO concentrations to levels $\leq 100 \mathrm{ppb}$ during power operation by addition of hydrogen and by minimizing DO in the makeup water. The guidelines further specify that DO levels must be reduced to $\leq 100 \mathrm{ppb}$ prior to exceeding $121^{\circ} \mathrm{C}\left(250^{\circ} \mathrm{F}\right)$ during plant heat-up by venting or vacuum filling followed by the use of hydrazine. Typically the DO levels are $5 \mathrm{ppb}$ or less during operation. The estimated probability curves show good agreement with experimental data; nearly all of the data are bounded by the $5 \%$ probability curve. The results also indicate that relative to the mean or $50 \%$ probability curve the $5 \%$ probability curve is a factor of $\approx 2.5$ lower in life at strain amplitudes $>0.3 \%$ and a factor of 1.4-1.7 lower in strain at $<0.2 \%$ strain amplitudes. Similarly, the $1 \%$ probability curve is a factor of $\approx 3.7$ lower in life and a factor of 1.7-2.2 lower in strain.

As with other aspects of this model, the interpretation with respect to probabilities should not be extrapolated much beyond the data. The probabilities assume normal distributions, which is consistent with the data for most of the range (see Section 5.3). It is important to have the exact distribution to estimate extremely low or high probabilities. However, the existing data are not sufficient to support such exact distributions; it takes more data to estimate distributions than to estimate the mean curve. The assumption of normality is reasonable (and conservative) down to between 0.1 and $1 \%$ probability of cracking; this is empirically verified by the number of data points that fall below the respective curves, e.g., in Fig. 21 about one percent of data points fall below the 1\% curve. For Types 304 and 316 SS tested in air, with a total of $\approx 500$ data points with which to estimate variance, this empirical test should identify major errors down to about $0.2 \%$ probability (just under 3 standard deviations). The probability is not expected to deviate significantly from the normal curve for another order of magnitude (one more standard deviation) even if the probability distribution is not the same. For this reason, probability distribution curves should not be extrapolated beyond $0.02 \%$ probability.

\section{Fatigue S-N Behavior of Components}

Several variables can influence fatigue life; these can be broadly classified into three groups:

1. Material
a. Composition: sulfur content
b. Metallurgy: grain size, inclusions, orientation within a forging or plate
c. Processing: cold work, heat treatment
d. Size and geometry
e. Surface finish: fabrication surface condition
f. Surface preparation: surface work hardening

2. Loading
a. Strain rate: rise time
b. History: linear damage summation or Miner's rule
c. Mean stress
d. Biaxial effects: constraints

3. Environment
a. Water chemistry: DO, lithium hydroxide, boric acid concentrations
b. Temperature
c. Flow rate 
The existing fatigue $\mathrm{S}-\mathrm{N}$ data base covers an adequate range of material parameters (a-c), a loading parameter (a), and environment parameters ( $a$ and $b$ ); therefore, the effects of these parameters have been incorporated into the model. Loading parameters ( $b$ and $d)$ are covered by design procedures and need not be considered in the S-N curves.

The existing data are conservative with respect to the effects of surface preparation because the fatigue $\mathrm{S}-\mathrm{N}$ data are obtained for specimens that are free of surface cold work, which typically gives longer fatigue lives. Fabrication procedures for fatigue test specimens generally follow ASTM guidelines which require that the final polishing of the specimens should avoid surface work hardening. The existing data are inadequate to evaluate the contributions of flow rate on fatigue life; most of the tests in water have been conducted at relatively low flow rates. Consequently, only the contributions of size, geometry, surface finish, and mean stress need to be considered in development of fatigue crack-initiation curves that are applicable to components.

\subsection{Effect of Size and Geometry}

The effect of specimen size on the fatigue life of CS and LAS has been investigated for smooth specimens of various diameters in the range of 2-60 mm. ${ }^{30-33}$ No intrinsic size effect has been observed for smooth specimens tested in axial loading or plain bending. However, a size effect does occur in specimens tested in rotating bending; fatigue endurance limit decreases by $\approx 25 \%$ by increasing the specimen size from 2 to $16 \mathrm{~mm}$ but does not decrease further for larger sizes. ${ }^{33}$ In addition, some effect of size and geometry has been observed on small-scale vessel tests conducted at Ecole Polytechnique in conjunction with the full-size pressure vessel tests carried out by Southwest Research Institute. 34 The tests at the Ecole Polytechnique were conducted in RT water on $\approx 305-\mathrm{mm}$ inner diameter, 19-mm-thick shells with nozzles made of machined bar stock. The results indicate that the number of cycles to form a 3-mm crack in an 19-mm-thick shell may be 30-50\% lower than those in a small test specimen. 20 Thus, a factor of $\approx 1.4$ on cycles and a factor of $\approx 1.25$ on strain can be used to account for size and geometry.

\subsection{Effect of Surface Finish}

Fatigue life is sensitive to surface finish; cracks can initiate at surface irregularities that are normal to the stress axis. The height, spacing, shape, and distribution of surface irregularities are important for crack initiation. The most common measure of roughness is average roughness $R_{a}$, which is a measure of the height of the irregularities. In addition, a wavelength parameter is used to characterize the spacing of the peaks and valleys of the surface, and a skewness parameter is a measure of the symmetry of the profile about the mean line.

Information is very limited on detailed characterization of surfaces in terms of height, shape, and distribution of surface irregularities produced by different manufacturing and fabrication processes. Typical values of average roughness for surfaces finished by different metalworking processes in the automotive industry (data from Ref. 35) are given in Table 11. Limited data on surface height distributions for mild steel surfaces finished by centerless grinding show a normal distribution, whereas surfaces finished by other methods are more peaked or asymmetrical than a normal distribution. 36 For the level of precision in the present 
Table 11. Typical average roughness values for surfaces finished by various processes

\begin{tabular}{ll}
\hline Process & $\mathrm{R}_{\mathrm{a}}(\mu \mathrm{m})$ \\
\hline Planing, shaping & $1-25$ \\
Milling & $1-6$ \\
Drawing, extrusion & $1-3$ \\
Turning, boring & $0.4-6$ \\
Grinding & $0.1-2$ \\
Honing & $0.1-1$ \\
Polishing & $0.1-0.4$ \\
Lapping & $0.05-0.4$ \\
Cast & $0.9-72$ \\
\hline
\end{tabular}

model and in the functional relationship between surface roughness and fatigue life given below, the exact distribution should not matter beyond the mean and variance.

Investigations of the effects of surface roughness on the low-cycle fatigue of Type 304 SS in air at $593^{\circ} \mathrm{C}$ indicate that fatigue life decreases as surface roughness increases. 37,38 The effect of roughness on crack initiation $N_{i}(R)$ is given by

$$
\mathrm{N}_{\mathrm{i}}\left(\mathrm{R}_{\mathrm{q}}\right)=1012 \mathrm{R}_{\mathrm{q}}^{-0.21} \text {, }
$$

where the RMS value of surface roughness $R_{q}$ is in $\mu \mathrm{m}$. A study of the effect of surface finish on fatigue life of CS in RT air showed a factor of 2 decrease in life when $R_{a}$ is increased from 0.3 to $5.3 \mu \mathrm{m} .{ }^{39}$ These results are consistent with Eq. 13 .

Table 11 shows that an $R_{a}$ of $3 \mu \mathrm{m}$ (or an $R_{q}$ of $4 \mu \mathrm{m}$ ) represents the maximum surface roughness for drawing/extrusion, grinding, honing, and polishing processes and mean value for the roughness range for milling or turning processes. For CS or LAS, an $\mathrm{R}_{\mathrm{q}}$ of $4 \mu \mathrm{m}$ in Eq. $13\left(\mathrm{R}_{\mathrm{q}}\right.$ of a smooth polished specimen is $\left.\approx 0.0075 \mu \mathrm{m}\right)$ would decrease fatigue life by a factor of $\approx 3.37$ No information on the effect of surface finish on endurance limit of CSs and LASs is available. It may be approximated as a factor of $\approx 1.3$ on strain.*

\subsection{Estimated Fatigue S-N Curves for Components}

The current ASME Section III Code design fatigue curves were based on experimental data on small polished test specimens. The best-fit curve to the experimental data, expressed in terms of stress amplitude $\mathrm{S}_{\mathrm{a}}$ and fatigue cycles $\mathrm{N}$, for CSs is given by

$$
\mathrm{S}_{\mathrm{a}}(\mathrm{ksi})=8,664 / \sqrt{ } \mathrm{N}+21.645 \text {, }
$$

for LASs by

$$
\mathrm{S}_{\mathrm{a}}(\mathrm{ksi})=7,139 / \sqrt{\mathrm{N}}+38.5 \text {, }
$$

and for austenitic SSs by

\footnotetext{
* The factor applied on strain $\left(\mathrm{K}_{\mathrm{S}}\right)$ is obtained from the factor applied on cycles $\left(\mathrm{K}_{\mathrm{N}}\right)$ by using the relationship $\mathrm{K}_{\mathrm{S}}=\left(\mathrm{K}_{\mathrm{N}}\right) \cdot 0.2326$
} 


$$
\mathrm{S}_{\mathrm{a}}(\mathrm{ksi})=8,415 / \sqrt{ } \mathrm{N}+43.5
$$

The stress amplitude $\mathrm{S}_{\mathrm{a}}$ is the product of strain amplitude $\varepsilon_{\mathrm{a}}$ and elastic modulus $\mathrm{E}$; the RT value of $30,000 \mathrm{ksi}$ for the elastic modulus was used in converting the experimental strain-vs.life data to stress-vs.-life curves. The best-fit curves were adjusted for the effect of mean stress by using the modified Goodman relation

$$
\mathrm{S}_{\mathrm{a}}^{\prime}=\mathrm{S}_{\mathrm{a}}\left(\frac{\sigma_{\mathrm{u}}-\sigma_{\mathrm{y}}}{\sigma_{\mathrm{u}}-\mathrm{S}_{\mathrm{a}}}\right) \quad \text { for } \mathrm{S}_{\mathrm{a}}<\sigma_{\mathrm{y}},
$$

and

$$
S_{a}^{\prime}=S_{a} \quad \text { for } S_{a}>\sigma_{y} \text {, }
$$

where $S_{a}^{\prime}$ is the adjusted value of stress amplitude, and $\sigma_{y}$ and $\sigma_{u}$ are yield and ultimate strengths of the material, respectively. The design fatigue curves were then obtained by lowering the adjusted best-fit curve by a factor of 2 on stress or 20 on cycles, whichever was more conservative, at each point on the curve. The factor of 20 on cycles was intended to account for the uncertainties in fatigue life associated with material and loading conditions, and the factor of 2 on strain was intended to account for uncertainties in threshold strain caused by material variability. The interim design curves were also developed by the same procedure. However, instead of a single curve, a family of best-fit experimental curves that vary with specific loading and environmental conditions were used. 19 This procedure for obtaining the design fatigue curves from best-fit experimental curves is illustrated for CSs and LASs in Fig. 24; $\mathrm{RT}$ values of tensile properties were used in Eq. 17 for mean-stress adjustment (the adjusted fatigue S-N curves for both the steels were represented by a single design curve in Section III of the ASME Code).

A similar approach is used in the statistical models to account for differences and uncertainties associated with size/geometry, surface roughness, and mean stress. The procedure is illustrated in Fig. 25. First, the best-fit or mean curve to the experimental data is adjusted for the effect of mean stress using the Goodman relation of Eq. 17. Note that the Goodman rela-
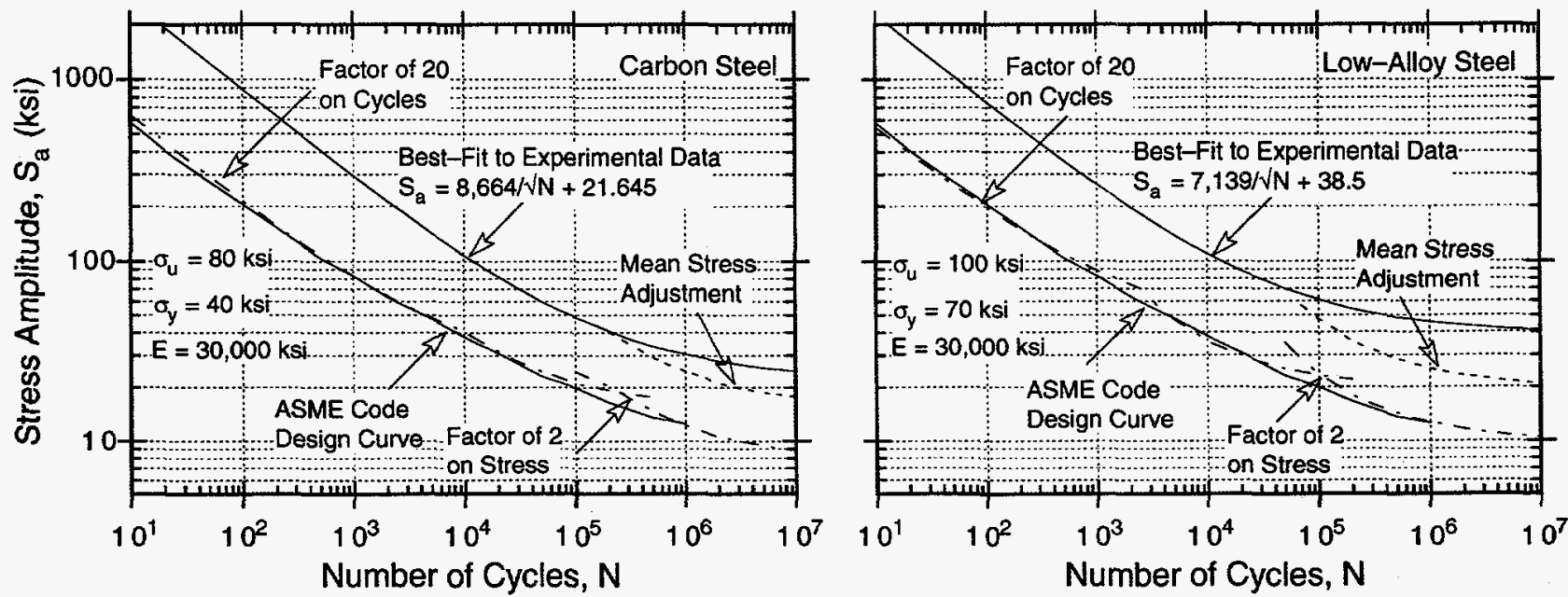

Figure 24. Adjustment for mean stress effects and factors of 2 and 20 applied to best-fit S-N curves for carbon and low-alloy steels to obtain the ASME Code design fatigue curve 

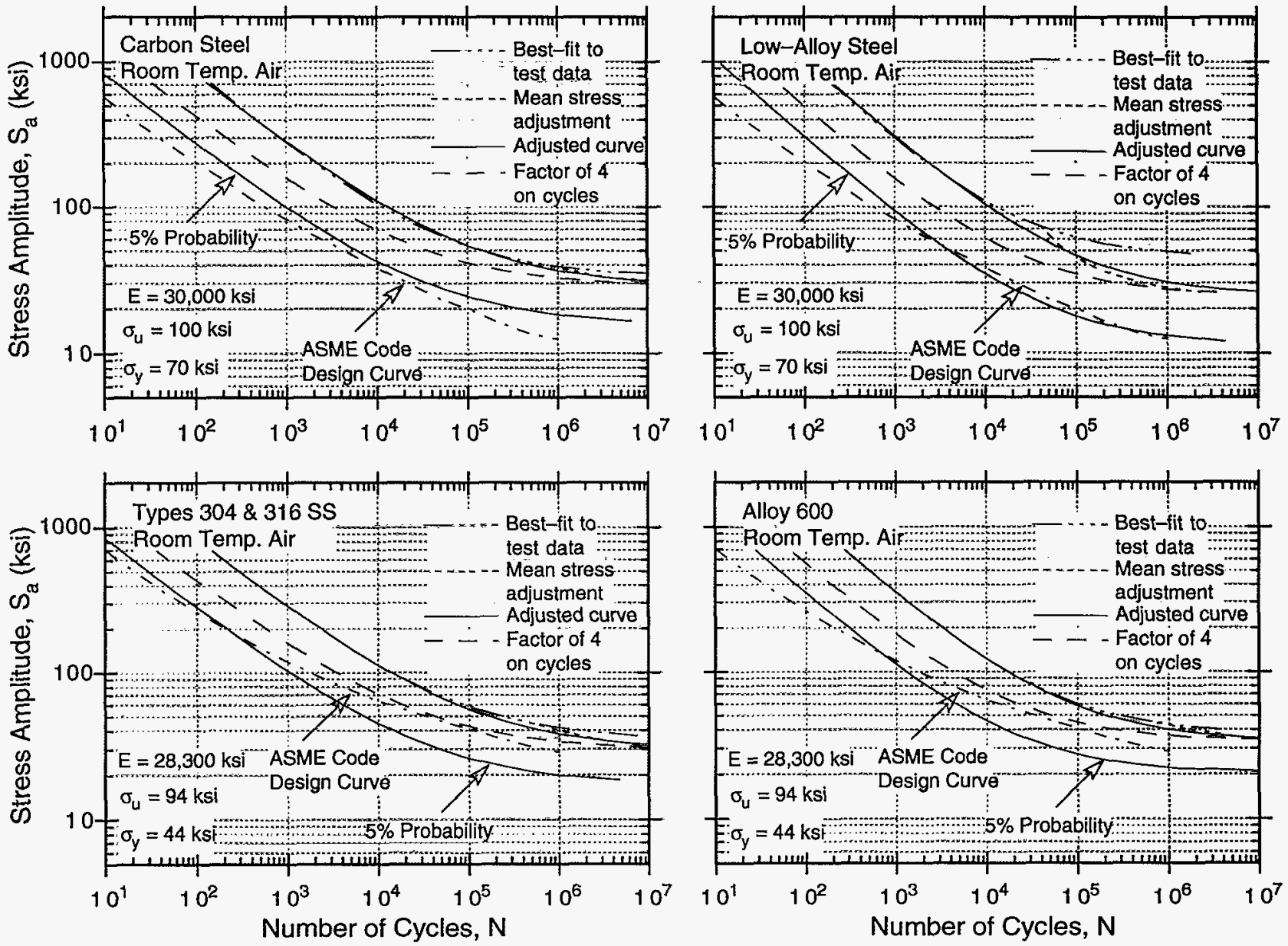

Figure 25. Procedure for translating probability distribution on fatigue life of laboratory test specimens to those of actual reactor components

tion assumes maximum possible mean stress and typically gives a conservative adjustment for mean stress at least when environmental effects are not significant. For CSs and LASs, the values of elastic modulus and tensile properties were the same as those used in adjusting the ASME Code design curve, e.g., cyclic yield and ultimate strength at room temperature, respectively, were 40 and $80 \mathrm{ksi}(276$ and $552 \mathrm{MPa}$ ) for CS and 70 and $100 \mathrm{ksi}$ (483 and $689 \mathrm{MPa}$ ) for LAS. A value of $207 \mathrm{GPa}(30,000 \mathrm{ksi})$ was used for elastic modulus for both CSs and LASs. A cyclic yield strength of $303 \mathrm{MPa}$ (44 ksi) and ultimate strength of $648 \mathrm{MPa}$ (94 ksi) was used for austenitic SSs as well as for Alloy 600;22 elastic modulus was 195 and $213 \mathrm{GPa}(28,300$ and $30,900 \mathrm{ksi})$, respectively, for SSs and Alloy 600 .

The effects of component size/geometry can be accounted for by lowering the probability curves for smooth test specimens by factors of 1.4 on cycles and 1.25 on strain, and the effects of component surface finish by lowering the curves by factors of 3 on cycles and 1.3 on strain. The factors on strain primarily account for the variation in threshold strain (i.e., fatigue endurance of the material) caused by component size or surface finish. The effect of these parameters on threshold strain are judged not to be cumulative but rather are controlled by the parameter that has the largest effect. Equations 10-12 indicate that relative to the mean curve ( $50 \%$ probability), the $5 \%$ probability for fatigue cracking in smooth test specimens is lower by 
a factor of 2.5 on cycles and 1.7 on strain. Consequently, a factor of 1.7 on strain (largest of $1.25,1.3$, and 1.7) is adequate to account for the variations in life associated with material variability, as well as for the effects of size/geometry and surface finish. This implies that for probabilities of $5 \%$ or less the probability distribution on strain, i.e., the term $0.026 \mathrm{~F}^{-1}[1-\mathrm{x}]$ in Eqs. 10-12, is adequate to account for the variation in life associated with material variability and the effects of size, geometry, and surface finish on threshold strain. The probability distribution curves for components can be obtained by lowering the mean-stress-adjusted curves for smooth specimens by a factor of 4 (i.e., product of 1.4 and 3 ) on cycles to include the effects of size/geometry and surface finish in the low-cycle regime.

The number of cycles $\mathrm{N}_{\mathrm{i}}(\mathrm{x})$ corresponding to the xth percentile of the probability for crack initiation in CS and LAS components is expressed by the equation

$$
\begin{aligned}
\ln \left[N_{i}(x)\right]= & \left(6.857-0.766 I_{W}\right)-\left(0.275-0.382 I_{W}\right) I_{S}+0.52 F^{-1}[x]-\ln \left(K_{N}\right) \\
& -\left(1.813+0.219 I_{S}\right) \ln \left(\varepsilon_{\mathrm{a}}-0.080-0.014 I_{S}+0.026 \mathrm{~F}^{-1}[1-\mathrm{X}]\right) \\
& \left.-0.00133 \mathrm{~T}\left(1-\mathrm{IW}_{\mathrm{W}}\right)+0.554 \mathrm{~S}^{*} \mathrm{~T}^{*} \mathrm{O}^{*} \dot{\varepsilon}^{*}\right),
\end{aligned}
$$

for austenitic SS components by

$$
\begin{aligned}
\ln \left[\mathrm{N}_{\mathrm{i}}(\mathrm{x})\right]= & 6.732+0.52 \mathrm{~F}^{-1}[\mathrm{x}]-\ln \left(\mathrm{K}_{\mathrm{N}}\right)-2.032 \ln \left(\varepsilon_{\mathrm{a}}-0.103+0.026 \mathrm{~F}^{-1}[1-\mathrm{x}]\right) \\
& +\mathrm{IW}\left(0.134 \dot{\varepsilon}^{*}-0.359\right)+0.382 \mathrm{I}_{316 \mathrm{NG}},
\end{aligned}
$$

and for Alloy 600 components by

$$
\begin{aligned}
\ln \left[\mathrm{N}_{\mathrm{i}}(\mathrm{x})\right] & =6.969+0.52 \mathrm{~F}^{-1}[\mathrm{x}]-\ln \left(\mathrm{K}_{\mathrm{N}}\right)-1.814 \ln \left(\varepsilon_{\mathrm{a}}-0.107+0.026 \mathrm{~F}^{-1}[1-\mathrm{x}]\right) \\
& +0.498 \mathrm{I}_{\mathrm{T}}-0.401 \mathrm{I}_{\mathrm{W}},
\end{aligned}
$$

where $\mathrm{K}_{\mathrm{N}}$ is the factor of 4 applied on cycles to account for the effects of component surface finish and size/geometry. In Eqs. 18-20, the intercept, coefficient of $\varepsilon_{\mathrm{a}}$, and threshold strain are different than those in Eqs. 10-12, because of the adjustment for mean stress effects. Also, note that the $0.52 \mathrm{~F}^{-1}[\mathrm{x}]$ term yields a negative value, and the $\left.0.026 \mathrm{~F}^{-1}[1-\mathrm{x}]\right)$ term a positive value for probabilities $<50$ th percentile, and the signs are reversed for values $>50$ th percentile.

The estimates based on Eq. 18 may be compared with results of the pressure vessel tests carried out by Southwest Research Institute. ${ }^{33}$ Fatigue $\mathrm{S}-\mathrm{N}$ curves that represent 1, 5, 25, 50, and $95 \%$ probability of cracking in CS and LAS components in RT water and the results of the vessel tests are shown in Fig. 26. The test data correspond to the number of cycles for formation of fatigue cracks and do not represent failure of the vessel. For both steels, the estimated curves are consistent with the test results; the data are bounded by $5 \%$ probability curve.

The estimated S-N curve representing 5\% probability of fatigue cracking in CS or LAS, austenitic SSs, and Alloy 600 components in RT air is compared with the ASME Code design fatigue curves in Fig. 25. The results indicate that for LASs, although the ASME mean curve and model best-fit experimental curve are nearly the same (Fig. 3), the $5 \%$ probability and Code design curves are significantly different; the Code curve represents $\approx 5 \%$ probability at stress amplitudes $<60 \mathrm{ksi}(<414 \mathrm{MPa})$ and $<5 \%$ probability at higher stresses. For CSs the ASME Code design curve represents $<5 \%$ probability at all stress levels. The Code design curve yields rather conservative estimates of design life of CSs because, as shown in Fig. 3, at $<0.2 \%$ strain amplitudes (stress amplitudes $<60 \mathrm{ksi}$ [ $<414 \mathrm{MPa}$ ), the ASME mean curve predicts significantly lower fatigue lives than those observed experimentally. The results also indicate 

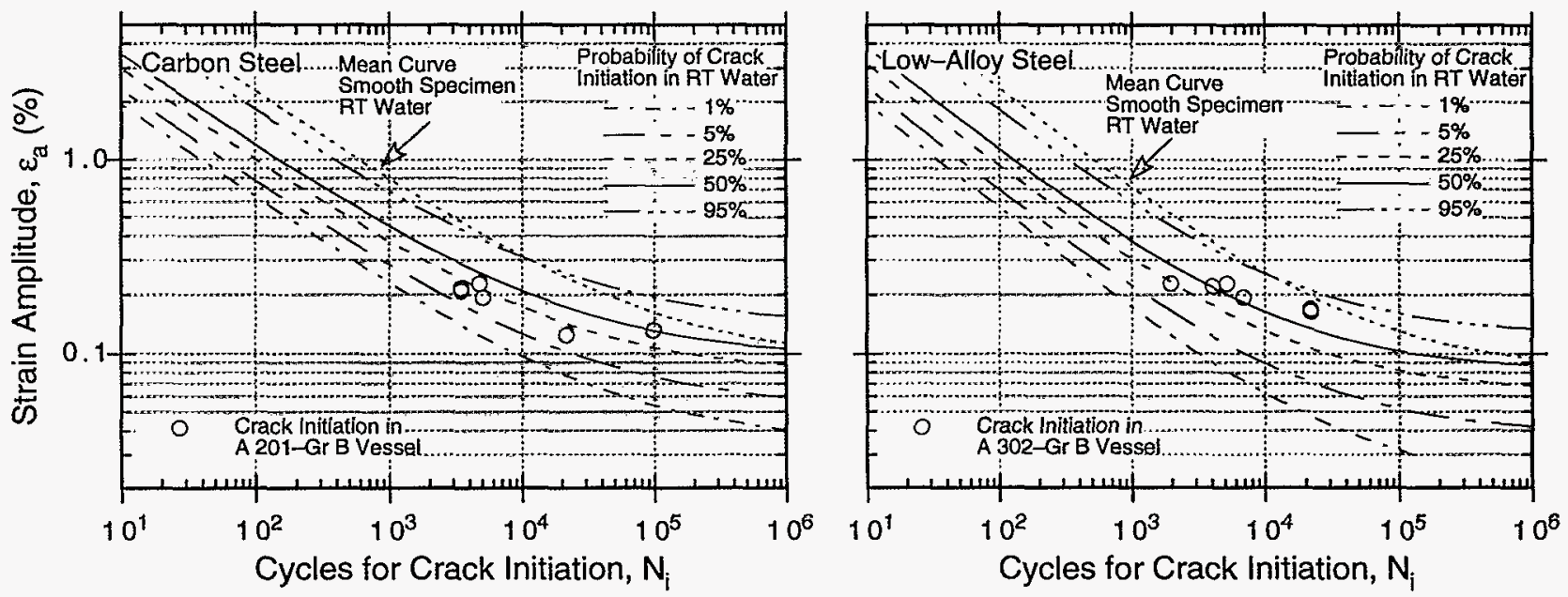

Figure 26. Probability of fatigue cracking in carbon and low-alloy steel vessel in roomtemperature water

that the current ASME Code design curve for austenitic SSs represents a relatively high probability of fatigue cracking, e.g., 25-50\% probability of cracking at stress amplitudes of 30$100 \mathrm{ksi}(207-690 \mathrm{MPa})$. The high probability of cracking for SSs occurs because at stress amplitudes $<150 \mathrm{ksi}$ ( $<1034 \mathrm{MPa}$ ), the mean curve upon which the Code design curve is based is not consistent with the experimental data and predicts significantly higher fatigue lives than those observed experimentally (Fig. 5).

The estimated probabilities of fatigue cracking in CS and LAS components in air and water environments are compared with the NUREG/CR-5999 proposed interim design curves and the ASME Code design curve in Figs. 27-30. The fatigue stress vs. life curves for the model were obtained by multiplying the strain amplitudes by the appropriate value of elastic modulus at the service temperature, i.e., $S_{a}=E \varepsilon_{a}$; note that the Code and interim design curves were obtained by using the RT value of elastic modulus. The values of elastic modulus for CSs and LASs, austenitic SSs, and Alloy 600, at different temperatures are listed in Table 12.

The results for CSs and LASs in $290^{\circ} \mathrm{C}$ air indicate that the ASME Code design curve represents a somewhat higher probability of fatigue cracking than in RT air (Figs. 25 and 27). For CS components, the ASME Code fatigue design curve represents $\approx 5 \%$ probability of fatigue cracking at $20-300 \mathrm{ksi}(138-2068 \mathrm{MPa})$ and $<5 \%$ probability at higher stress levels; for LAS components, the Code curve represents $5-25 \%$ probability at $10-150 \mathrm{ksi}(69-1034 \mathrm{MPa})$ and lower probability at higher stresses.

The results for CSs and LASs in $290^{\circ} \mathrm{C}$ air indicate that the ASME Code design curve represents a somewhat higher probability of fatigue cracking than in RT air (Figs. 25 and 27). For CS components, the ASME Code fatigue design curve represents $\approx 5 \%$ probability of fatigue cracking at $20-300 \mathrm{ksi}(138-2068 \mathrm{MPa})$ and $<5 \%$ probability at higher stress levels; for LAS components, the Code curve represents 5-25\% probability at 10-150 ksi (69-1034 MPa) and lower probability at higher stresses.

The estimated probability of fatigue cracking for CS and LASs in low-DO water (PWR water, Fig. 28) and in high-DO water (which is a somewhat conservative estimate for BWR envi- 
Table 12. Values of elastic modulus for carbon and low-alloy steels, austenitic stainless steels, and Alloy 600, MPa (x1000 ksi)

\begin{tabular}{lccccc}
\hline \multicolumn{1}{c}{ Material } & $25^{\circ} \mathrm{C}$ & $150^{\circ} \mathrm{C}$ & $200^{\circ} \mathrm{C}$ & $250^{\circ} \mathrm{C}$ & $290^{\circ} \mathrm{C}$ \\
\hline Carbon Steel & $203.4(29.5)$ & $194.4(28.2)$ & $191.7(27.8)$ & $188.9(27.4)$ & $186.2(27.0)$ \\
Low-Alloy Steel & $201.3(29.2)$ & $192.4(27.9)$ & $189.6(27.5)$ & $186.8(27.1)$ & $184.1(26.7)$ \\
Stainless Steel & $195.1(28.3)$ & $186.2(27.0)$ & $182.7(26.5)$ & $179.3(26.0)$ & $175.4(25.5)$ \\
Alloy 600 & $213.0(30.9)$ & $205.5(29.8)$ & $203.4(29.5)$ & $201.3(29.2)$ & $198.6(28.8)$ \\
\hline
\end{tabular}
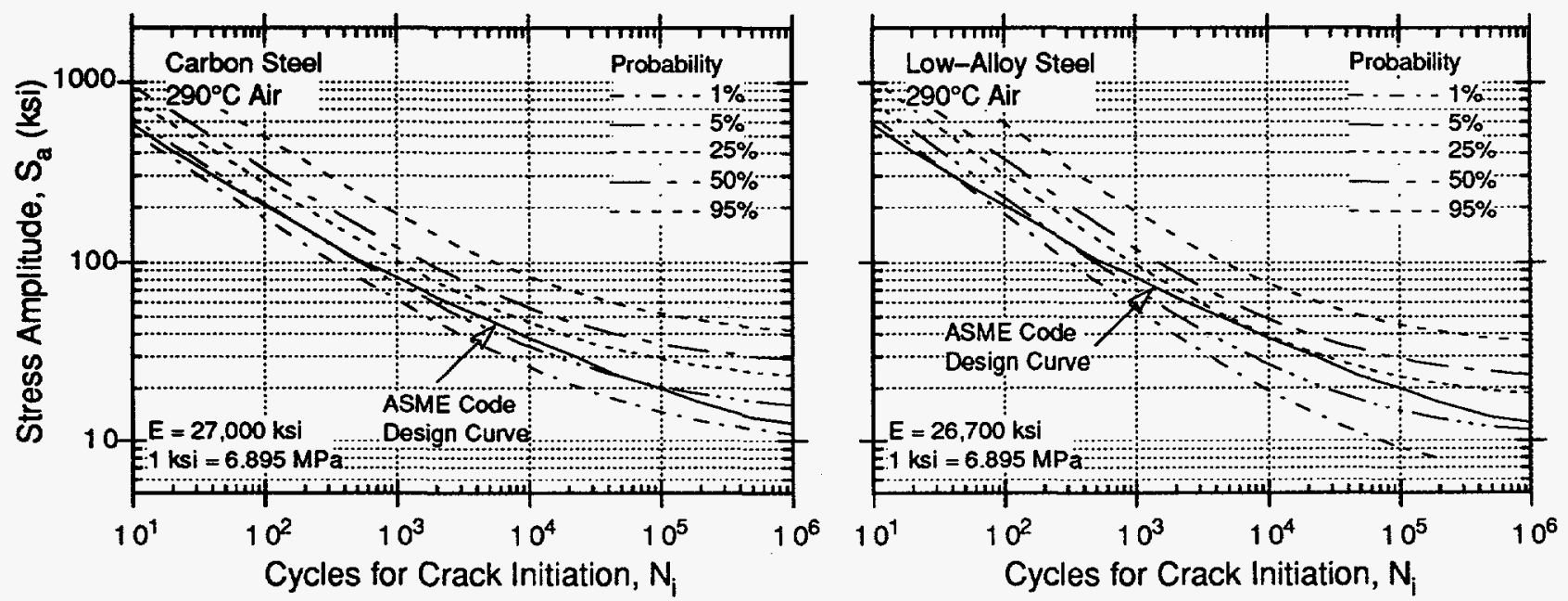

Figure 27. Probability of fatigue cracking in carbon and low-alloy steels in air at $290^{\circ} \mathrm{C}$, and the ASME Code design curve
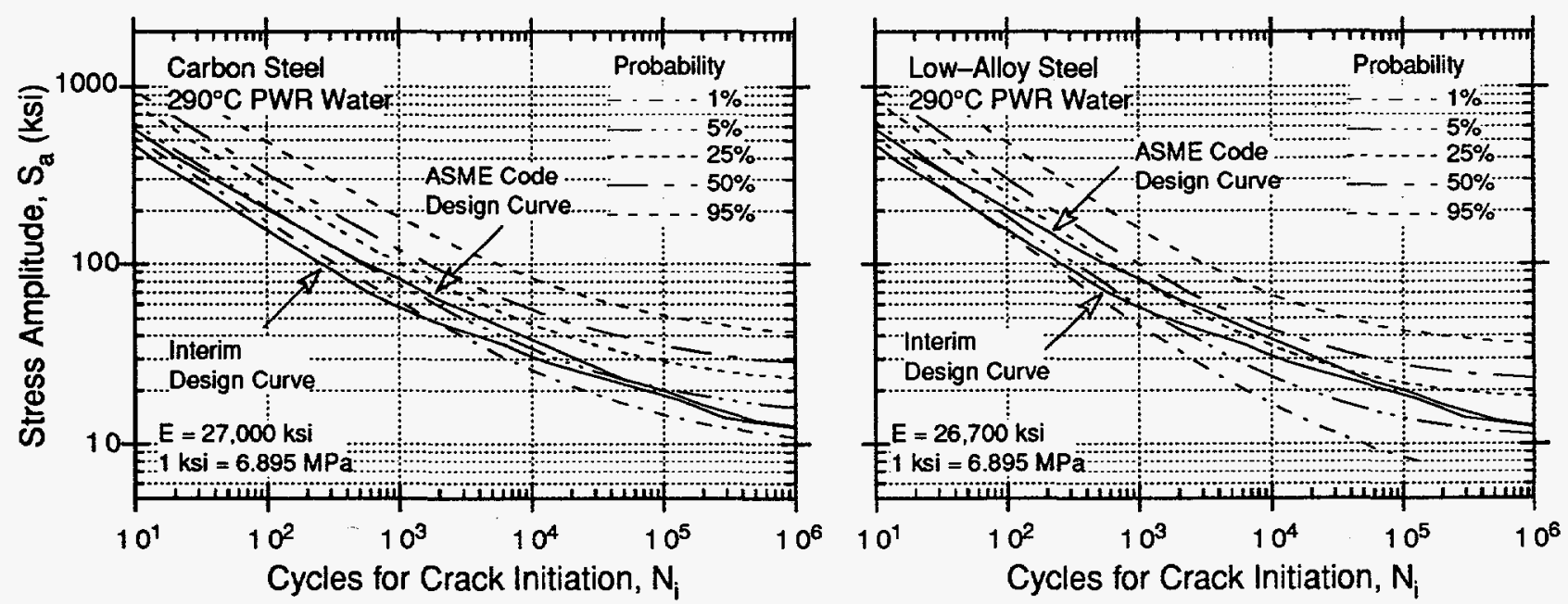

Figure 28. Probability of fatigue cracking in carbon and low-alloy steels in PWR water, the proposed interim design curve in water with $<0.1 \mathrm{ppm} D O$, and the ASME design curve 

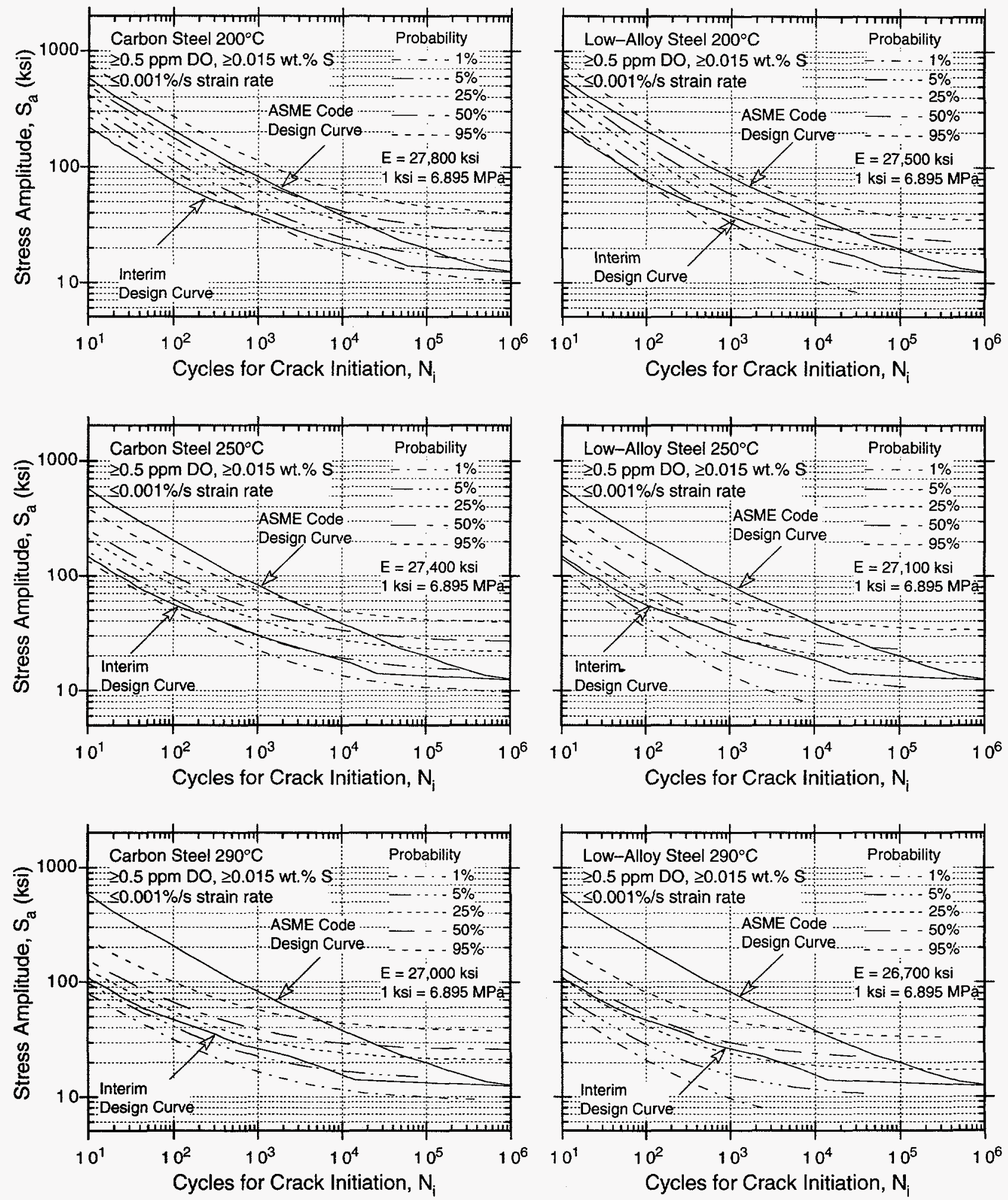

Figure 29. Probability of fatigue cracking in carbon and low-alloy steels at 200,250 , and $290^{\circ} \mathrm{C}$ and $0.001 \% / \mathrm{s}$ strain rate in water with DO levels $\geq 0.5 \mathrm{ppm}$, the proposed interim design curve for carbon steel in water with $>0.1 \mathrm{ppm} D O$, and the ASME design curve 

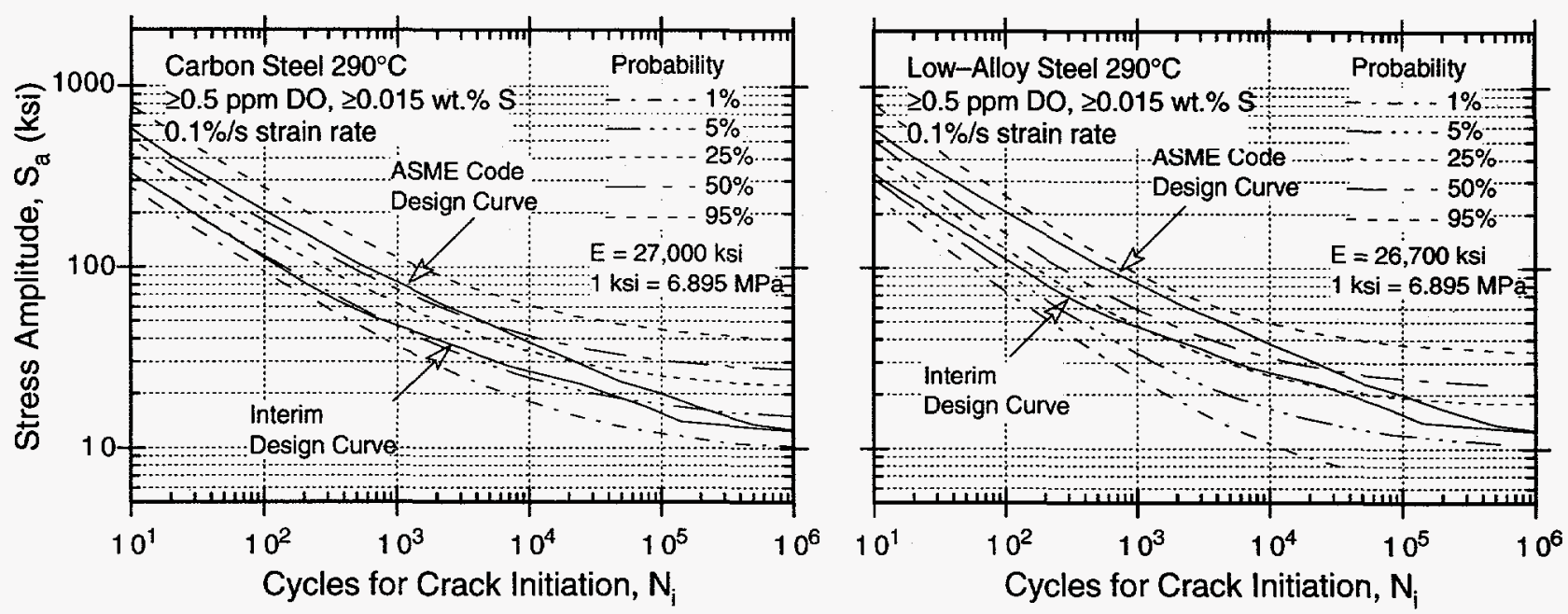

Figure 30. Probability of fatigue cracking in carbon and low-alloy steels at $290^{\circ} \mathrm{C}$ and $0.1 \% / \mathrm{s}$ strain rate in water with $D O$ levels $\geq 0.5 \mathrm{ppm}$, the proposed interim design curve for carbon steel in water with $>0.1 \mathrm{ppm} D O$, and the ASME design curve

ronment, Figs. 29 and 30), indicate that for a specific service condition the NUREG/CR-5999 interim design curves represent a lower probability of cracking in CS components $11-5 \%$ probability) than in LAS components (5-25\% probability). The higher probability for LASs is due to the fact that a common best-fit experimental curve is used for both CSs and LASs in developing the interim design curves, whereas separate best-fit experimental curves are used in the statistical model. The results show that the current ASME Code fatigue design curve for CSs and LASs does not adequately address the effect of environment on fatigue life in high-DO water at high stress amplitudes. Typically, the Code fatigue curve represents $>50 \%$ probability of fatigue cracking for stress amplitudes $>30 \mathrm{ksi}(207 \mathrm{MPa})$.

The estimated probabilities of fatigue cracking in austenitic SS and Alloy 600 components in air and water environments are compared with the NUREG/CR-5999 interim design curve and the ASME Code design curve in Figs. 31 and 32. As discussed earlier in this section, the results indicate that the current Code design curve for austenitic SSs represents a relatively high probability of fatigue cracking at stress amplitudes of 30-100 ksi (207-690 MPa) because the mean curve upon which the Code design curve is based is not consistent with the experimental data. For austenitic SSs, the interim design curve represents 5-20\% probability of cracking in water. The probability of fatigue cracking for Type $316 \mathrm{NG}$ components is somewhat lower than that for Types 304 and 316 SS. The results for Alloy 600 indicate that the interim design curves may be very conservative at stress levels above $50 \mathrm{ksi}$ ( $345 \mathrm{MPa}$ ).

Equations 18-20 were also used to estimate the probability of fatigue cracking as a function of cumulative usage factor (CUF). Plots of the probability of fatigue cracking in carbon steel, low-alloy steel, and austenitic SS components as a function of CUF at different applied strain amplitudes are presented in the Appendix. The CUFs were calculated with the interim fatigue design curves that correspond to low-DO water typical of PWRs and high-DO water representing a somewhat conservative estimate for BWRs. As expected, the probability of fatigue cracking increases with increasing CUF. However, because the curves of constant probability are not parallel, for a given CUF, the probability also depends on the applied strain amplitude. 

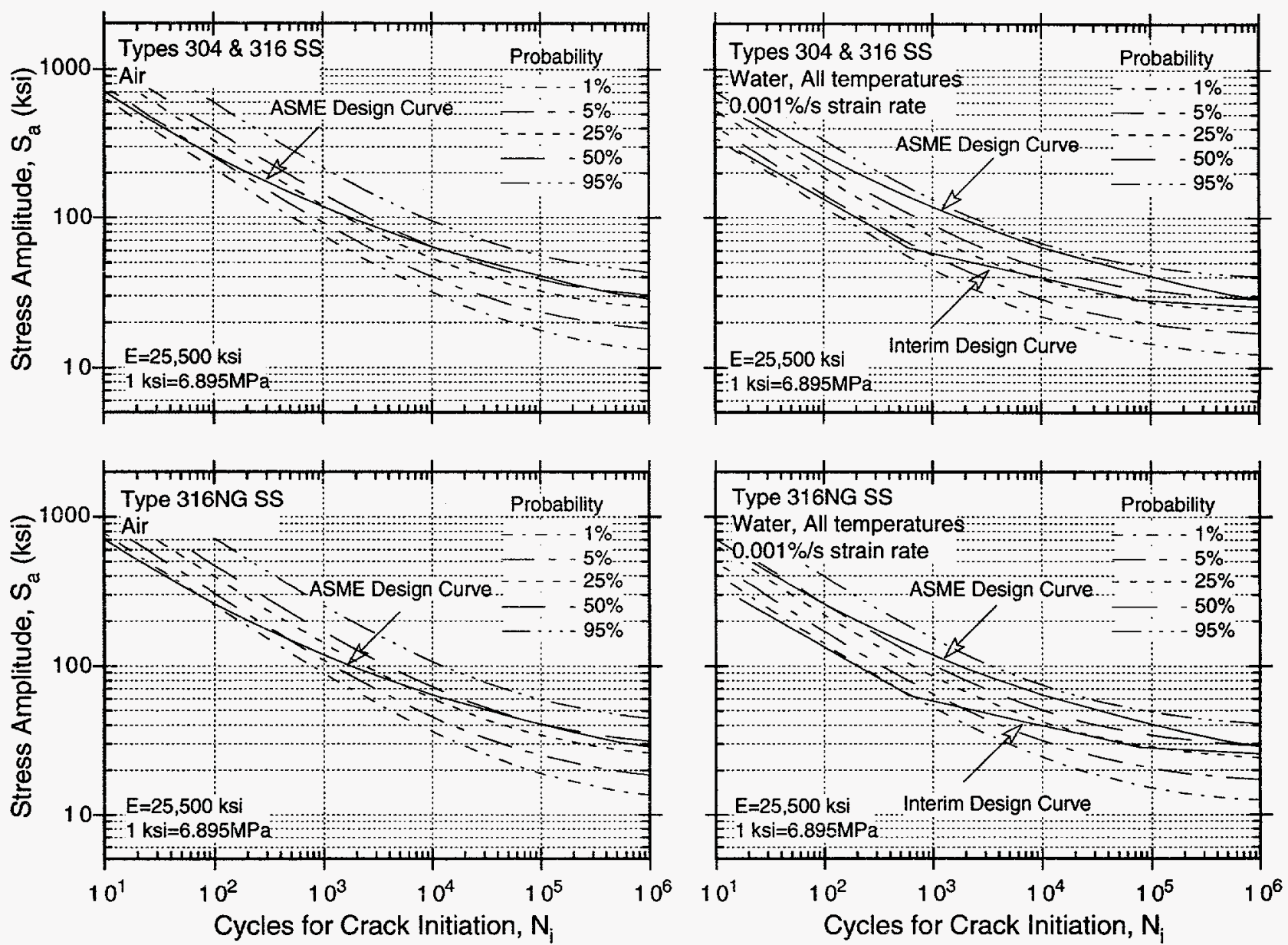

Figure 31. Probability of fatigue cracking in austenitic stainless steels in air and water environments at $290^{\circ} \mathrm{C}$
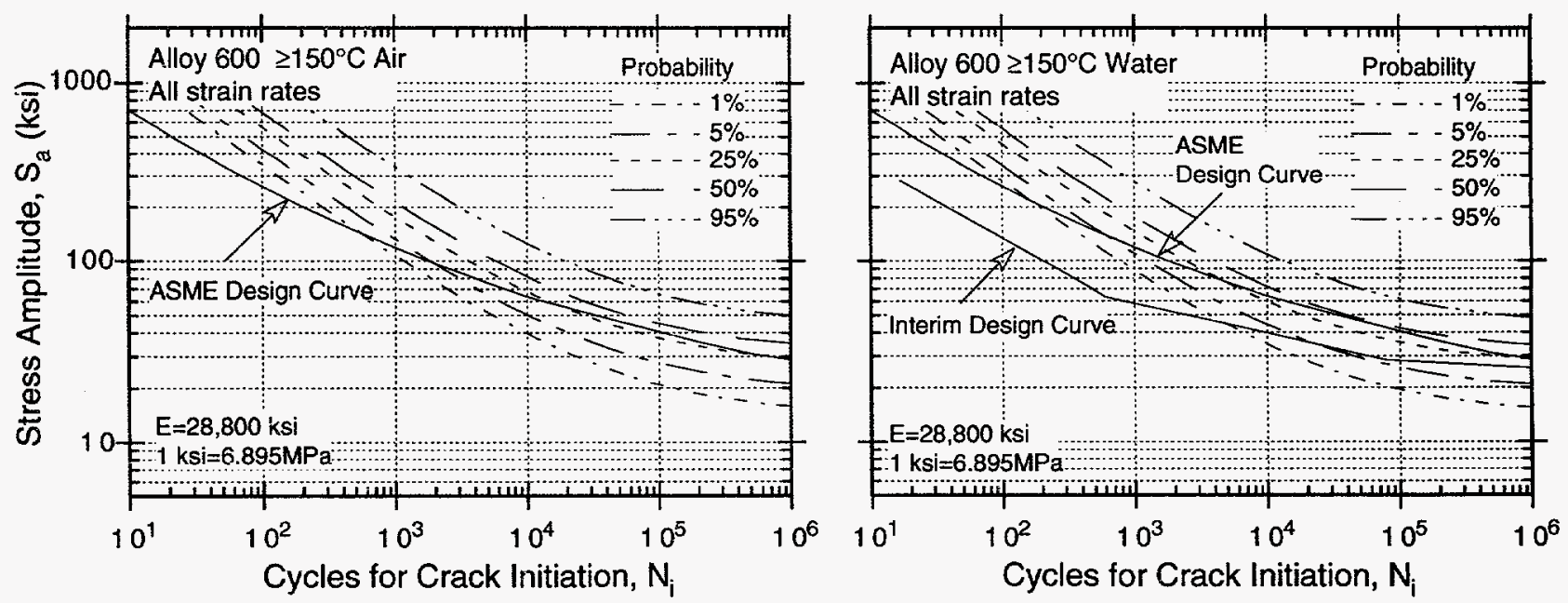

Figure 32. Probability of fatigue cracking in Alloy 600 in air and water environments at $290^{\circ} \mathrm{C}$ 
Examples of estimating the probability of fatigue cracking in specific reactor components are also included in the Appendix.

\section{Conclusions}

The existing fatigue S-N data from the U.S. and Japan for carbon and low-alloy ferritic steels, austenitic SSs, and Alloy 600 have been compiled and categorized according to material, loading, and environmental conditions. Experimental fatigue S-N data are considered to represent the number of cycles required to initiate a 3-mm-deep surface crack in a smooth specimen. For each type of material, statistical models have been developed to estimate the effects of various material, loading, and environmental variables on their fatigue life. The results of the analysis have been used to estimate the probability of initiating fatigue cracks in smooth test specimens. Fatigue $\mathrm{S}-\mathrm{N}$ curves for components have been determined by adjusting the best-fit experimental curve for the effect of mean stress and then setting margins for size, geometry, and surface finish to the probability distribution curves for test specimens. Data available in the literature were reviewed to evaluate the effects of size, geometry, and surface finish of a component on its fatigue life. The data indicate that a factor of $\approx 4$ may be used to account for size/geometry and surface roughness of the component.

The probability curves estimated from the statistical models have been used to evaluate the current ASME Code design curves and the proposed interim design curves in NUREG/CR5999. The results indicate that in air at stress levels $<60 \mathrm{ksi}(<414 \mathrm{MPa})$, the ASME mean curve for CSs is conservative with respect to the data, i.e., it predicts lower fatigue lives than those observed experimentally. Furthermore, the current ASME Code fatigue design curve for CSs and LASs does not adequately address the effect of environment on fatigue life in high-DO water. For stress amplitudes $>30 \mathrm{ksi}(207 \mathrm{MPa})$, the Code fatigue curve represents a $>50 \%$ probability of fatigue cracking.

The results also indicate that at stress levels $<150 \mathrm{ksi}(<1034 \mathrm{MPa})$, the current ASME Code design curve for austenitic SSs is nonconservative with respect to the data, i.e., it predicts longer fatigue lives than those observed experimentally. The ASME Code curve represents a relatively high probability of fatigue cracking, e.g., a 25-50\% probability of cracking in $290^{\circ} \mathrm{C}$ air at stress amplitudes of $30-100 \mathrm{ksi}(207-690 \mathrm{MPa})$ and a $>50 \%$ probability of fatigue cracking in water at all stress levels.

For a specific service condition, the interim design curves represent a lower probability of cracking in CS components (1-5\% probability) than in LAS components (5-25\% probability). The interim design curve for SSs represents a 5-20\% probability of cracking for Types 304 and 316 SS in water; the probability for Type $316 \mathrm{NG}$ components is somewhat lower. The interim design curves may be overly conservative for Alloy 600 at stress levels above $50 \mathrm{ksi}$ (345 MPa).

The statistical models have also been used to assess the significance of the proposed interim fatigue design curves published in NUREG/CR-5999 on fatigue evaluation of reactor components. The probabilities of fatigue cracking in carbon and low-alloy ferritic steel, austenitic stainless steel, and Alloy 600 components have been estimated as a function of CUF for various service conditions. Estimations of the probability of fatigue cracking in sample components from BWRs and PWRs are presented. 
1. ASME Boiler and Pressure Vessel Code Section III - Rules for Construction of Nuclear Power Plant Components, The American Society of Mechanical Engineers, 345 East 47th Street, New York, NY 10017, 1992 Edition.

2. Criteria of Section III of the ASME Boiler and Pressure Vessel Code for Nuclear Vessels, The American Society of Mechanical Engineers, United Engineering Center, New York, Library of Congress Catalog No. 56-3934 (1989).

3. Tentative Structural Design Basis for Reactor Pressure Vessels and Directly Associated Components (Pressurized, Water Cooled Systems), PB 151987, U.S. Dept. of Commerce, Office of Technical Service, 1 Dec. 1958 Revision.

4. D. A. Hale, S. A. Wilson, E. Kiss, and A. J. Gianuzzi, Low Cycle Fatigue Evaluation of Primary Piping Materials in a BWR Environment, GEAP-20244, U.S. Nuclear Regulatory Commission (Sept. 1977).

5. D. A. Hale, S. A. Wilson, J. N. Kass, and E. Kiss, "Low Cycle Fatigue Behavior of Commercial Piping Materials in a BWR Environment," J. Eng. Mater. Technol. 103, 15-25 (1981).

6. S. Ranganath, J. N. Kass, and J. D. Heald, "Fatigue Behavior of Carbon Steel Components in High-Temperature Water Environments," in Low-Cycle Fatigue and Life Prediction, ASTM STP 770, C. Amzallag, B. N. Leis, and P. Rabbe, eds., American Society for Testing and Materials, Philadelphia, PA, pp. 436-459 (1982).

7. S. Ranganath, J. N. Kass, and J. D. Heald, "Fatigue Behavior of Carbon Steel Components in High-Temperature Water Environments," in BWR Environmental Cracking Margins for Carbon Steel Piping, EPRI NP-2406, Electric Power Reasearch Institute, Palo Alto, CA, Appendix 3 (May 1982).

8. J. B. Terrell, Fatigue Life Characterization of Smooth and Notched Piping Steel Specimens in $288^{\circ} \mathrm{C}$ Air Environments, NUREG/CR-5013, MEA-2232 (May 1988).

9. J. B. Terrell, Fatigue Strength of Smooth and Notched Specimens of ASME SA 106-B Steel in PWR Environments, NUREG/CR-5136. MEA-2289 (Sept. 1988).

10. J. B. Terrell, "Effect of Cyclic Frequency on the Fatigue Life of ASME SA-106-B Piping Steel in PWR Environments," J. Mater. Eng. 10,193-203 (1988).

11. P. D. Hicks, "Fatigue of Ferritic Steels," in Environmentally Assisted Cracking in Light Water Reactors: Semiannual Report October 1990-March 1991, NUREG/CR-4667 Vol. 12, ANL-91/24, pp. 3-18 (Aug. 1991).

12. P. D. Hicks and W. J. Shack, "Fatigue of Ferritic Steels," in Environmentally Assisted Cracking in Light Water Reactors, Semiannual Report, April-September 1991, NUREG/CR4667 Vol. 13, ANL-92/6, pp. 3-8 (March 1992). 
13. O. K. Chopra, W. F. Michaud, and W. J. Shack, "Fatigue of Ferritic Steels," in Environmentally Assisted Cracking in Light Water Reactors, Semiannual Report, October 1992-March 1993, NUREG/CR-4667 Vol. 16, ANL-93/27, pp. 3-19 (Sept. 1993).

14. O. K. Chopra, W. F. Michaud, W. J. Shack, and W. K. Soppet "Fatigue of Ferritic Steels," in Environmentally Assisted Cracking in Light Water Reactors, Semiannual Report, AprilSeptember 1993, NUREG/CR-4667 Vol. 17, ANL-94/16, pp. 3-19 (June 1994).

15. O. K. Chopra and W. J. Shack, "Effects of LWR Environments on Fatigue Life of Carbon and Low-Alloy Steels," Proc. ASME Pressure Vessel and Piping Conf., Honolulu, HI, 1995.

16. M. Higuchi and K. Iida, "Fatigue Strength Correction Factors for Carbon and Low-Alloy Steels in Oxygen-Containing High-Temperature Water," Nucl. Eng. Des. 129, 293-306 (1991).

17. K. Iida, H. Kobayashi, and M. Higuchi, Predictive Method of Low Cycle Fatigue Life of Carbon and Low Alloy Steels in High Temperature Water Environments, NUREG/CP-0067, MEA-2090, Vol. 2 (April 1986).

18. N. Nagata, S. Sato, and Y. Katada, "Low-Cycle Fatigue Behavior of Low-Alloy Steels in High-Temperature Pressurized Water," in Transactions of the 10th International Conf. on Structural Mechanics in Reactor Technology. Vol. F, A. H. Hadjian, ed., American Association for Structural Mechanics in Reactor Technology, Anaheim, CA (1989).

19. S. Majumdar, O. K. Chopra, and W. J. Shack, Interim Fatigue Design Curves for Carbon, Low-Alloy, and Austenitic Stainless Steels in LWR Environments, NUREG/CR-5999, ANL93/3 (April 1993).

20. J. Keisler, O. K. Chopra, and W. J. Shack, Statistical Analysis of Fatigue Strain-Life Data for Carbon and Low-Alloy Steels, NUREG/CR-6237, ANL-94/2 1 (Aug. 1994).

21. B. A. James, L. D. Paul, and M. T. Miglin, "Low Cycle Fatigue Crack Initiation in SA-210 Al Carbon Steel Boiler Tubing in Contaminated Boiler Water," Fatigue, Degradation and Fracture, PVP-Vol. 195, W. H. Bamford, C. Becht, S. B. Bhandari, J. D. Gilman, L. A. James, and M. Prager, eds., American Society of Mechanical Engineers, New York, pp. 1319 (1990).

22. C. E. Jaske and W. J. O'Donnell, "Fatigue Design Criteria for Pressure Vessel Alloys," Trans. ASME J. Pressure Vessel Technology 99, 584-592 (1977).

23. J. B. Conway, R. H. Stentz, and J. T. Berling, Fatigue, Tensile, and Relaxation Behavior of Stainless Steels, TID-26135, U.S. Atomic Energy Commission, Washington, DC (1975).

24. D. L. Keller, Progress on LMFBR Cladding, Structural, and Component Materials Studies During July, 1971 through June, 1972, Final Report, Task 32, Battelle-Columbus Laboratories, BMI-1928 (1977). 
25. W. J. Shack and W. F. Burke, "Fatigue of Type 316NG SS," in Environmentally Assisted Cracking in Light Water Reactors, Semiannual Report, October 1989-March 1990, NUREG/CR-4667 Vol. 10, ANL-91/5, pp. 3-19 (March 1991).

26. B. F. Langer, "Design of Pressure Vessels for Low-Cycle Fatigue," ASME J. of Basic Engineering 84, 389-402 (1962).

27. A. G. Ware, D. K. Morton, and M. E. Nitzel, Application of NUREG/CR-5999 Interim Design Curves to Selected Nuclear Power Plant Components, NUREG/CR-6260, INEL-95/0045 (March 1995).

28. A. E. Dinerman, Cyclic Strain Fatigue of Inconel at 75 and $600^{\circ} \mathrm{F}$, KAPL-2084 (Aug. 1960).

29. PWR Primary Water Chemistry Guidelines: Revision 2, EPRI NP-7077, Project 2493, Final Report, Electric Power Reasearch Institute, Palo Alto, CA, (November 1990).

30. R. E. Peterson, "Fatigue Tests of Small Specimens with Particular Reference to Size Effect," in Trans. Amer. Soc. Steel Testing 18, 1041-1053 (1930).

31. D. Morkovin and H. F. Moore, "Third Progress Report on the Effect of Size of Specimen on Fatigue Strength of Three Types of Steel," Proc. Amer. Soc. Test. Mater. 44, 137-158 (1944).

32. C. E. Philips and R. B. Heywood, "The Size Effect in Fatigue of Plain and Notched Steel Specimens Loaded Under Reversed Direct Stress," Proc. Inst. Mech. Engr. 165, 113-124 (1951).

33. C. Massonnet, "The Effect of Size, Shape, and Grain Size on the Fatigue Strength of Medium Carbon Steel," Proc. Amer. Soc. Test. Mater. 56, 954-978 (1956).

34. L. F. Kooistra, E. A. Lange, and A. G. Pickett, "Full-Size Pressure Vessel Testing and Its Application to Design," J. Eng. Power, 86, 419-428 (1964).

35. K. J. Stout, "Surface Roughness - Measurement, Interpretation, and Significance of Data," Mater. Eng. 2, 287-295 (1981).

36. W. Watson, T. G. King, T. A. Spedding, and K. J. Stout, "The Machined Surface - Time Series Modelling," Wear 57, 195-205 (1979).

37. P. S. Maiya and D. E. Busch, "Effect of Surface Roughness on Low-Cycle Fatigue Behavior of Type 304 Stainless Steel," Met. Trans. 6A, 1761-1766 (1975).

38. P. S. Maiya, "Effect of Surface Roughness and Strain Range on Low-Cycle Fatigue Behavior of Type 304 Stainless Steel," Scripta Metall. 9, 1277-1282 (1975).

39. K. Iida, "A Study of Surface Finish Effect Factor in ASME B \& PV Code Section III," in Pressure Vessel Technology Vol. 2, L. Cengdian and R. W. Nichols, eds., Pergamon Press, New York, pp. 727-734 (1989). 


\section{Appendix}

\section{Estimation of Probability of Fatigue Cracking in Reactor Components}

Statistical models were used to assess the significance of the proposed interim fatigue design curves published in NUREG/CR-5999, "Interim Fatigue Design Curves for Carbon, LowAlloy, and Austenitic Stainless Steels," in fatigue evaluation of reactor components. The probabilities of fatigue cracking in carbon and low-alloy ferritic steel, austenitic stainless steel, and Alloy 600 components have been estimated as a function of cumulative usage factor (CUF) for various service conditions. The CUFs were calculated using the interim fatigue design curves corresponding to low dissolved oxygen (DO) water typical of PWRs or high-DO water representing a conservative estimate of environmental effects on fatigue life in BWRs. The probability of fatigue cracking was estimated from Eqs. 18-20 (presented in Section 7.3). The procedure for estimating the probability of fatigue crack initiation at different CUFs and service conditions is as follows:

(a) For a specific material, the loading, and environmental conditions determine the allowable cycles at different stress levels from the NUREG/CR-5999 interim design curves. The interim design curves for carbon and low-alloy steels in PWR water at all temperatures and strain rates and in high-DO ( $\geq 0.1 \mathrm{ppm})$ water at different strain rates and 200,250 , and $290^{\circ} \mathrm{C}$, are shown in Fig. A-1. The interim design curve for austenitic stainless steels is shown in Fig. A-2; it is applicable for all temperatures and strain rates and is used also for Alloy 600 .

(b) The stress-cycles data sets in (a) represent a CUF of 1. For a given stress amplitude, determine the number of cycles corresponding to CUF values between 0.01 and 10 .

(c) Convert the stress amplitude to a strain amplitude by using the appropriate elastic modulus at temperature. The high-temperature value of elastic modulus is used for situations where $\mathrm{N}_{\mathrm{i}}(\mathrm{x})$ is independent of temperature, e.g., carbon steel in PWR water or austenitic stainless steels in water.

(d) For this strain level, compute the number of cycles corresponding to the xth percentile of the probability for crack initiation and compare with the number of cycles corresponding to a given CUF to determine the probability of cracking as a function of CUF.

The procedure was translated into a spreadsheet that takes as input a set of conditions, and yields as output the probability of fatigue cracking under those conditions. The results for various service and material conditions are listed in Tables A-1 through A-6 and plotted in Figs. A-3 through A-8. For convenience, values of the inverse of standard normal cumulative distribution function in Eqs. 18-20 are given in Table A-7. As discussed earlier in Section 6, probability distributions should not be extrapolated much beyond the data. The assumption of normal distribution is reasonable down to about $0.2 \%$, i.e., just under three standard deviations. The probability is not expected to deviate significantly from the normal curve for another order of magnitude, i.e., one more standard deviation, even if the probability distribution is not the same. For this reason, probability distribution curves are truncated at $0.02 \%$ and are shown with a dotted line between 0.02 and $0.2 \%$ probability. 
As expected, the probability of fatigue cracking increases with increasing CUF. However, because the curves of constant probability are not parallel, for a given CUF, the probability also depends on the applied stress amplitude. This dependence on stress amplitude is relatively weak for high stress levels, but at low stresses the probability is quite sensitive to the stress amplitude. At stress amplitudes below the mean threshold strain, probability of cracking is relatively insensitive to CUF values above 0.2 . (The mean threshold strain amplitudes are $0.11,0.15$, and $0.12 \%$ for carbon steel, low-alloy steel, and austenitic SS, respectively.)

Although these results seem somewhat surprising upon first examination, they do seem heuristically plausible upon further reflection. Because the scatter in life is so large at low strain amplitudes, the probability of fatigue crack initiation in this region is not very well characterized by cycle counting, i.e., CUF. Rather, the probability of fatigue cracking is controlled primarily by the uncertainty in threshold strain for the material. This is reflected in the relative insensitivity to CUF value. Because we have relatively little threshold data, the uncertainty in the probability estimates at low strain amplitudes is probably rather large. We believe that the curves presented here are conservative. A sensitivity calculation in which the standard deviation for the threshold stress was decreased by a factor of 2 showed a substantial decrease in the absolute values of the probabilities for low strain amplitudes.

Furthermore, the results indicate that at CUF values $<1$, the probability of cracking increases with decreasing stress amplitude whereas, at CUF values $>1$, probability of cracking decreases with decreasing stress. This behavior is due to the differences in the shape of the constant CUF and the probability curves. The constant CUF curves are parallel to the design curve, i.e., they are obtained by applying a constant factor on cycles. The probability curves are obtained by applying factors on cycles and on strain.

For strain amplitudes above the mean threshold strain where fatigue damage is well characterized by CUF, a CUF of 1 calculated from NUREG/CR-5999 interim design fatigue curves represents probability of $0.3-3 \%$ for carbon steel in PWR water, 10-20\% for carbon steel in high-DO water, $1-15 \%$ for low-alloy steel in PWR water, 25-40\% for low-alloy steel in high-DO water, $1-15 \%$ for austenitic SSs in water, and $<4 \%$ for Alloy 600 . These probabilities should be interpreted as the probabilities for initiating a macroscopic crack and do not necessarily imply failure of the component.

These results may be used for estimating the probability of fatigue cracking in specific reactor components. Fatigue evaluations for ten components, six from PWRs and four from BWRs, are given in Tables A 8-A 17. The stress record and corresponding usage factor for the components was obtained from NUREG/CR-6260, "Application of NUREG/CR-5999 Interim Fatigue Curves to Selected Nuclear Power Plant Components." For each component, the information listed in the tables includes the alternating stress intensities for different load pairs, anticipated number of cycles, allowable cycles at that stress based on NUREG/CR-5999, and the usage factor. The probability of fatigue cracking can be estimated from the CUF for the component. Because the loading histories involve a range of stress amplitudes, probability values were estimated corresponding to three stress levels, e.g., maximum, minimum, and mid or average stress, within the range where $>80 \%$ of the fatigue usage is accumulated for the component; the results are given in Tables A-8 through A-17. 
Table A-1. Allowable cycles ${ }^{a}$ and probability of fatigue cracking in low-alloy steel components in PWR water as a function of cumulative usage factor at different applied stress amplitudes

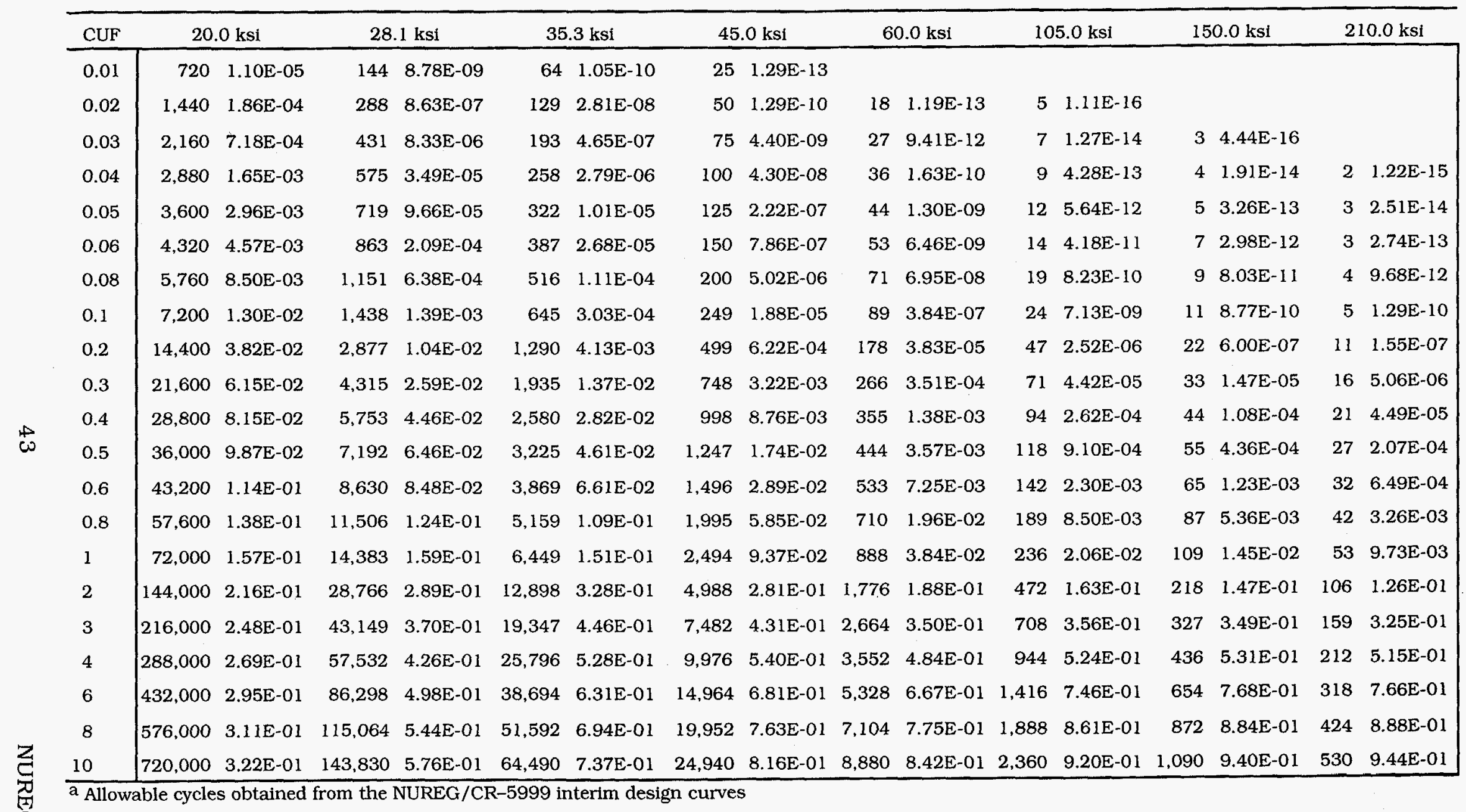




\begin{tabular}{|c|c|c|c|c|c|c|c|c|c|c|c|c|c|c|c|c|}
\hline \multirow{2}{*}{$\frac{\text { CUF }}{0.01}$} & \multicolumn{2}{|c|}{$22.5 \mathrm{ksi}$} & \multicolumn{2}{|c|}{$28.1 \mathrm{ksi}$} & \multicolumn{2}{|c|}{$35.3 \mathrm{ksi}$} & \multicolumn{2}{|c|}{$45.0 \mathrm{ksi}$} & \multicolumn{2}{|c|}{$60.0 \mathrm{ksi}$} & \multicolumn{2}{|c|}{$105.0 \mathrm{ksi}$} & \multicolumn{2}{|c|}{$150.0 \mathrm{ksi}$} & \multicolumn{2}{|c|}{$210.0 \mathrm{ksi}$} \\
\hline & 24 & $2.90 \mathrm{E}-04$ & 7 & $4.81 \mathrm{E}-06$ & 3 & $2.36 \mathrm{E}-07$ & 1 & $1.81 \mathrm{E}-09$ & & & & & & & & \\
\hline 0.02 & & $2.59 \mathrm{E}-03$ & 14 & $1.36 \mathrm{E}-04$ & 6 & $1.56 \mathrm{E}-05$ & 2 & $3.79 \mathrm{E}-07$ & & & & & & & & \\
\hline 0.03 & & $7.15 \mathrm{E}-03$ & 21 & $6.73 \mathrm{E}-04$ & 9 & $1.19 \mathrm{E}-04$ & 4 & $5.38 \mathrm{E}-06$ & 1 & $7.47 \mathrm{E}-08$ & & & & & & \\
\hline 0.04 & 97 & $1.32 \mathrm{E}-02$ & 28 & $1.81 \mathrm{E}-03$ & 13 & $4.25 \mathrm{E}-04$ & 5 & $2.89 \mathrm{E}-05$ & 2 & $6.61 \mathrm{E}-07$ & & & & & & \\
\hline 0.05 & 121 & $2.03 \mathrm{E}-02$ & 35 & $3.61 \mathrm{E}-03$ & 16 & $1.04 \mathrm{E}-03$ & 6 & $9.51 \mathrm{E}-05$ & 2 & $3.14 \mathrm{E}-06$ & & & & & & \\
\hline 0.06 & 146 & $2.78 \mathrm{E}-02$ & 42 & $6.05 \mathrm{E}-03$ & 19 & $2.04 \mathrm{E}-03$ & 7 & $2.35 \mathrm{E}-04$ & 3 & $1.04 \mathrm{E}-05$ & & & & & & \\
\hline 0.08 & 194 & $4.32 \mathrm{E}-02$ & 56 & $1.26 \mathrm{E}-02$ & 25 & $5.32 \mathrm{E}-03$ & 10 & $8.65 \mathrm{E}-04$ & 3 & $5.89 \mathrm{E}-05$ & & & & & & \\
\hline 0.1 & 243 & $5.84 \mathrm{E}-02$ & 70 & $2.09 \mathrm{E}-02$ & 31 & $1.03 \mathrm{E}-02$ & 12 & $2.15 \mathrm{E}-03$ & 4 & $2.01 E-04$ & 1 & $1.65 \mathrm{E}-05$ & & & & \\
\hline 0.2 & 485 & $1.22 \mathrm{E}-01$ & 140 & $7.30 \mathrm{E}-02$ & 63 & $5.42 \mathrm{E}-02$ & 24 & $2.16 \mathrm{E}-02$ & 9 & $4.80 \mathrm{E}-03$ & 2 & $1.10 \mathrm{E}-03$ & 1 & $4.91 \mathrm{E}-04$ & & \\
\hline 0.3 & 728 & $1.68 \mathrm{E}-01$ & 210 & $1.26 \mathrm{E}-01$ & 94 & $1.11 \mathrm{E}-01$ & 36 & $6.00 \mathrm{E}-02$ & 13 & $2.02 \mathrm{E}-02$ & 3 & $7.53 \mathrm{E}-03$ & 2 & $4.33 \mathrm{E}-03$ & & \\
\hline 0.4 & 971 & $2.03 \mathrm{E}-01$ & 280 & $1.73 \mathrm{E}-01$ & 126 & $1.69 \mathrm{E}-01$ & 48 & $1.09 \mathrm{E}-01$ & 17 & $4.72 \mathrm{E}-02$ & 4 & $2.35 \mathrm{E}-02$ & 2 & $1.57 \mathrm{E}-02$ & 1 & $2.61 \mathrm{E}-02$ \\
\hline 0.5 & 1,214 & $2.30 \mathrm{E}-01$ & 350 & $2.13 \mathrm{E}-01$ & 157 & $2.22 \mathrm{E}-01$ & 61 & $1.61 \mathrm{E}-01$ & 22 & $8.30 \mathrm{E}-02$ & 6 & $5.01 \mathrm{E}-02$ & 3 & $3.72 \mathrm{E}-02$ & 2 & $5.96 \mathrm{E}-02$ \\
\hline 0.6 & 1,456 & $2.51 \mathrm{E}-01$ & 420 & $2.48 \mathrm{E}-01$ & 188 & $2.70 \mathrm{E}-01$ & 73 & $2.12 \mathrm{E}-01$ & 26 & $1.24 \mathrm{E}-01$ & 7 & $8.62 \mathrm{E}-02$ & 3 & $6.87 \mathrm{E}-02$ & 2 & $1.07 \mathrm{E}-01$ \\
\hline 0.8 & 1,942 & $2.85 \mathrm{E}-01$ & 560 & $3.05 \mathrm{E}-01$ & 251 & $3.51 \mathrm{E}-01$ & 97 & $3.08 \mathrm{E}-01$ & 34 & $2.14 \mathrm{E}-\mathrm{OI}$ & 9 & $1.77 \mathrm{E}-01$ & 4 & $1.55 \mathrm{E}-01$ & 2 & $2.26 \mathrm{E}-01$ \\
\hline 1 & 2,427 & $3.09 \mathrm{E}-01$ & 700 & $3.50 \mathrm{E}-01$ & 314 & 4.17E-01 & 121 & $3.91 \mathrm{E}-01$ & 43 & $3.02 \mathrm{E}-01$ & 11 & $2.78 \mathrm{E}-01$ & 5 & $2.57 \mathrm{E}-01$ & 3 & $3.55 \mathrm{E}-01$ \\
\hline 2 & 4,854 & $3.77 \mathrm{E}-01$ & 1,400 & $4.81 \mathrm{E}-01$ & 628 & $6.06 \mathrm{E}-01$ & 242 & $6.46 \mathrm{E}-01$ & 86 & $6.21 \mathrm{E}-01$ & 22 & $6.72 \mathrm{E}-01$ & 10 & $6.81 \mathrm{E}-01$ & 6 & $7.91 \mathrm{E}-01$ \\
\hline 3 & 7,281 & $4.10 \mathrm{E}-01$ & 2,100 & $5.46 \mathrm{E}-\mathrm{O} 1$ & 942 & $6.97 \mathrm{E}-01$ & 363 & $7.66 \mathrm{E}-01$ & 129 & $7.79 \mathrm{E}-0 \mathrm{l}$ & 33 & $8.51 \mathrm{E}-01$ & 15 & $8.69 \mathrm{E}-01$ & 9 & $9.33 \mathrm{E}-01$ \\
\hline 4 & 9,708 & $4.31 \mathrm{E}-01$ & 2,800 & $5.87 \mathrm{E}-01$ & 1,256 & $7.50 \mathrm{E}-01$ & 484 & $8.31 E-01$ & 172 & $8.61 \mathrm{E}-01$ & 44 & $9.28 \mathrm{E}-01$ & 20 & $9.43 \mathrm{E}-01$ & 12 & $9.76 \mathrm{E}-01$ \\
\hline 6 & 14,562 & $4.56 \mathrm{E}-01$ & 4,200 & $6.36 \mathrm{E}-01$ & 1,884 & $8.10 \mathrm{E}-01$ & 726 & $8.98 \mathrm{E}-01$ & 258 & 9.35E-O1 & 66 & $9.79 \mathrm{E}-01$ & 30 & $9.87 \mathrm{E}-01$ & 18 & $9.96 \mathrm{E}-01$ \\
\hline 8 & 19,416 & $4.71 \mathrm{E}-01$ & 5,600 & $6.65 \mathrm{E}-01$ & 2,512 & $8.43 \mathrm{E}-01$ & 968 & $9.30 \mathrm{E}-01$ & 344 & $9.64 \mathrm{E}-01$ & 88 & $9.93 \mathrm{E}-01$ & 40 & $9.96 \mathrm{E}-01$ & 24 & $9.99 \mathrm{E}-01$ \\
\hline 10 & 24,270 & $4.81 \mathrm{E}-01$ & 7,000 & $6.85 \mathrm{E}-01$ & 3,140 & $8.64 \mathrm{E}-01$ & 1,210 & $9.48 \mathrm{E}-01$ & 430 & $9.79 \mathrm{E}-01$ & 110 & $9.97 \mathrm{E}-01$ & 50 & $9.99 \mathrm{E}-01$ & 30 & $1.00 E+00$ \\
\hline
\end{tabular}

a Allowable cycles obtained from the NUREG/CR-5999 interim design curves 
Table A-3. Allowable cycles ${ }^{a}$ and probability of fatigue cracking in carbon steel components in PWR water as a function of cumulative usage factor at different applied stress amplitudes

\begin{tabular}{|c|c|c|c|c|c|c|c|c|c|c|c|c|c|c|c|c|}
\hline \multirow{2}{*}{$\frac{\text { CUF }}{0.01}$} & \multicolumn{2}{|c|}{$20.0 \mathrm{ksi}$} & \multicolumn{2}{|c|}{$28.1 \mathrm{ksi}$} & \multicolumn{2}{|c|}{$35.3 \mathrm{ksi}$} & \multicolumn{2}{|c|}{$45.0 \mathrm{ksi}$} & \multicolumn{2}{|c|}{$60.0 \mathrm{ksi}$} & \multicolumn{2}{|c|}{$105.0 \mathrm{ksi}$} & \multicolumn{2}{|c|}{$150.0 \mathrm{ksi}$} & \multicolumn{2}{|c|}{$210.0 \mathrm{ksi}$} \\
\hline & 720 & $1.55 \mathrm{E}-07$ & 144 & $5.65 \mathrm{E}-11$ & 64 & $5.29 E-13$ & 25 & $5.55 E-16$ & & & & & & & & \\
\hline 0.02 & 1,440 & $4.44 \mathrm{E}-06$ & 288 & $9.52 \mathrm{E}-09$ & 129 & $2.41 \mathrm{E}-10$ & 50 & $8.52 \mathrm{E}-13$ & 18 & $6.66 \mathrm{E}-16$ & & & & & & \\
\hline 0.03 & 2,160 & $2.30 \mathrm{E}-05$ & 431 & $1.26 \mathrm{E}-07$ & 193 & $5.48 \mathrm{E}-09$ & 75 & $3.93 \mathrm{E}-11$ & 27 & $7.39 \mathrm{E}-14$ & 7 & $2.22 \mathrm{E}-16$ & & & & \\
\hline 0.04 & 2,880 & $6.49 \mathrm{E}-05$ & 575 & $6.65 \mathrm{E}-07$ & 258 & $4.13 \mathrm{E}-08$ & 100 & $4.78 \mathrm{E}-10$ & 36 & $1.57 \mathrm{E}-12$ & 9 & $7.55 \mathrm{E}-15$ & 4 & $6.66 \mathrm{E}-16$ & 2 & $1.11 \mathrm{E}-16$ \\
\hline 0.05 & 3,600 & $1.35 \mathrm{E}-04$ & 719 & 2. $19 \mathrm{E}-06$ & 322 & $1.78 \mathrm{E}-07$ & 125 & $2.95 \mathrm{E}-09$ & 44 & $1.47 \mathrm{E}-11$ & 12 & $1.15 E-13$ & 5 & $1.29 \mathrm{E}-14$ & 3 & $2.22 \mathrm{E}-15$ \\
\hline 0.06 & 4,320 & $2.37 \mathrm{E}-04$ & 863 & $5.47 \mathrm{E}-06$ & 387 & $5.48 \mathrm{E}-07$ & 150 & $1.20 \mathrm{E}-08$ & 53 & $8.41 E-11$ & 14 & $9.53 E-13$ & 7 & $1.29 \mathrm{E}-13$ & 3 & $2.53 \mathrm{E}-14$ \\
\hline 0.08 & 5,760 & $5.31 \mathrm{E}-04$ & 1,151 & $2.09 \mathrm{E}-05$ & 516 & $2.86 \mathrm{E}-06$ & 200 & $9.68 \mathrm{E}-08$ & 71 & $1.12 \mathrm{E}-09$ & 19 & $2.26 \mathrm{E}-11$ & 9 & $4.04 \mathrm{E}-12$ & 4 & $1.00 \mathrm{E}-12$ \\
\hline 0.1 & 7,200 & $9.37 \mathrm{E}-04$ & 1,438 & $5.42 \mathrm{E}-05$ & 645 & $9.37 \mathrm{E}-06$ & 249 & $4.35 \mathrm{E}-07$ & 89 & 7.39E-09 & 24 & $2.26 \mathrm{E}-10$ & 11 & $4.98 \mathrm{E}-11$ & 5 & $1.46 \mathrm{E}-11$ \\
\hline 0.2 & 14,400 & $4.10 \mathrm{E}-03$ & 2,877 & $6.77 \mathrm{E}-04$ & 1,290 & $2.22 \mathrm{E}-04$ & 499 & $2.54 \mathrm{E}-05$ & 178 & $1.28 \mathrm{E}-06$ & 47 & $1.30 \mathrm{E}-07$ & 22 & $5.08 \mathrm{E}-08$ & 11 & $2.35 \mathrm{E}-08$ \\
\hline 0.3 & 21,600 & $8.15 \mathrm{E}-03$ & 4,315 & $2.25 \mathrm{E}-03$ & 1,935 & $1.01 \mathrm{E}-03$ & 748 & $1.84 \mathrm{E}-04$ & 266 & $1.64 \mathrm{E}-05$ & 71 & $3.05 E-06$ & 33 & $1.59 \mathrm{E}-06$ & 16 & $9.26 \mathrm{E}-07$ \\
\hline 0.4 & 28,800 & $1.24 \mathrm{E}-02$ & 5,753 & $4.71 \mathrm{E}-03$ & 2,580 & $2.60 \mathrm{E}-03$ & 998 & $6.33 \mathrm{E}-04$ & 355 & $8.20 \mathrm{E}-05$ & 94 & $2.25 \mathrm{E}-05$ & 44 & $1.40 \mathrm{E}-05$ & 21 & $9.43 \mathrm{E}-06$ \\
\hline 0.5 & 36,000 & $1.66 \mathrm{E}-02$ & 7,192 & $7.89 \mathrm{E}-03$ & 3,225 & $5.01 \mathrm{E}-03$ & 1,247 & $1.51 \mathrm{E}-03$ & 444 & $2.56 \mathrm{E} \sim 04$ & 118 & $9.24 \mathrm{E}-05$ & 55 & $6.55 \mathrm{E}-05$ & 27 & $4.85 \mathrm{E}-05$ \\
\hline 0.6 & 43,200 & $2.06 \mathrm{E}-02$ & 8,630 & $1.16 \mathrm{E}-02$ & 3,869 & $8.19 \mathrm{E}-03$ & 1,496 & $2.90 \mathrm{E}-03$ & 533 & $6.05 \mathrm{E}-04$ & 142 & $2.69 \mathrm{E}-04$ & 65 & $2.09 \mathrm{E}-04$ & 32 & $1.67 \mathrm{E}-04$ \\
\hline 0.8 & 57,600 & $2.80 \mathrm{E}-02$ & 11,506 & $2.01 \mathrm{E}-02$ & 5,159 & $1.65 \mathrm{E}-02$ & 1,995 & $7.39 \mathrm{E}-03$ & 710 & $2.09 \mathrm{E} \sim 03$ & 189 & $1.24 \mathrm{E}-03$ & 87 & $1.10 \mathrm{E}-03$ & 42 & $9.71 \mathrm{E}-04$ \\
\hline 1 & 72,000 & $3.46 \mathrm{E}-02$ & 14,383 & $2.94 \mathrm{E}-02$ & 6.449 & $2.67 E-02$ & 2,494 & $1.41 \mathrm{E}-02$ & 888 & $4.93 E-03$ & 236 & $3.59 \mathrm{E}-03$ & 109 & $3.46 \mathrm{E}-03$ & 53 & $3.26 \mathrm{E}-03$ \\
\hline 2 & 144,000 & $5.89 \mathrm{E}-02$ & 28,766 & $7.59 \mathrm{E}-02$ & 12,898 & $8.89 \mathrm{E}-02$ & 4,988 & 7.04E-02 & 1,776 & $4.25 \mathrm{E}-02$ & 472 & $4.90 \mathrm{E}-02$ & 218 & $5.63 \mathrm{E}-02$ & 106 & 6.07E-02 \\
\hline 3 & 216,000 & $7.48 \mathrm{E}-02$ & 43,149 & $1.16 \mathrm{E}-01$ & 19,347 & $1.50 \mathrm{E}-01$ & 7,482 & $1.41 \mathrm{E}-01$ & 2,664 & $1.08 \mathrm{E}-01$ & 708 & $1.45 \mathrm{E}-01$ & 327 & $1.74 \mathrm{E}-01$ & 159 & $1.93 \mathrm{E}-01$ \\
\hline 4 & 288,000 & $8.64 \mathrm{E}-02$ & 57,532 & $1.48 \mathrm{E}-01$ & 25,796 & $2.04 \mathrm{E}-01$ & 9,976 & $2.10 \mathrm{E}-01$ & 3,552 & $1.83 \mathrm{E}-01$ & 944 & $2.61 \mathrm{E}-01$ & 436 & $3.14 \mathrm{E}-01$ & 212 & $3.51 \mathrm{E}-01$ \\
\hline 6 & 432,000 & $1.02 \mathrm{E}-01$ & 86,298 & $1.99 \mathrm{E}-01$ & 38,694 & $2.89 \mathrm{E}-01$ & 14,964 & $3.29 \mathrm{E}-01$ & 5,328 & $3.29 \mathrm{E}-01$ & 1,416 & $4.78 \mathrm{E}-01$ & 654 & $5.62 \mathrm{E}-01$ & 318 & $6.16 \mathrm{E}-01$ \\
\hline 8 & 576,000 & $1.13 E-01$ & 115,064 & $2.36 \mathrm{E}-01$ & 51,592 & $3.53 E-01$ & 19,952 & $4.22 \mathrm{E}-01$ & 7,104 & $4.49 \mathrm{E}-01$ & 1,888 & $6.39 E-01$ & 872 & $7.28 \mathrm{E}-01$ & 424 & $7.81 E-01$ \\
\hline 10 & 720,000 & $1.22 \mathrm{E}-01$ & 143,830 & $2.65 \mathrm{E}-01$ & 64,490 & $4.03 \mathrm{E}-01$ & 24,940 & $4.95 \mathrm{E}-01$ & 8,880 & $5.44 \mathrm{E}-01$ & 2,360 & $7.49 \mathrm{E}-01$ & 1,090 & $8.31 \mathrm{E}-01$ & 530 & $8.75 \mathrm{E}-01$ \\
\hline
\end{tabular}




\begin{tabular}{|c|c|c|c|c|c|c|c|c|c|c|c|c|c|c|c|c|}
\hline & & $\begin{array}{l}\text { wable } \\
\text { ction of }\end{array}$ & $\begin{array}{l}\text { les } \\
\text { zula }\end{array}$ & $\begin{array}{l}\text { nd pro } \\
\text { e usag }\end{array}$ & $\begin{array}{l}\text { ilits } \\
\text { cto }\end{array}$ & $\begin{array}{l}\text { fatigu } \\
\text { differe }\end{array}$ & $\begin{array}{l}a c k \\
\text { appl }\end{array}$ & $\begin{array}{l}\text { in } c c \\
\text { stres }\end{array}$ & ipl & $\begin{array}{l}\text { el corr } \\
\text { ides }\end{array}$ & $e r$ & $2 \mathrm{nug}$ & & ea 0 & & ter $a$ \\
\hline \multirow{2}{*}{$\frac{\text { CUF }}{0.01}$} & \multicolumn{2}{|c|}{$22.5 \mathrm{ksi}$} & \multicolumn{2}{|c|}{$28.1 \mathrm{ksl}$} & \multicolumn{2}{|c|}{$35.3 \mathrm{ksi}$} & \multicolumn{2}{|c|}{$45.0 \mathrm{kst}$} & \multicolumn{2}{|c|}{$60.0 \mathrm{ksi}$} & \multicolumn{2}{|c|}{$105.0 \mathrm{ksi}$} & \multicolumn{2}{|r|}{150.0} & \multicolumn{2}{|r|}{210.0} \\
\hline & 24 & $7.67 \mathrm{E}-06$ & 7 & $6.73 E-08$ & 3 & $2.56 \mathrm{E}-09$ & I & $1.49 \mathrm{E}-11$ & & & & & & & & \\
\hline 0.02 & 49 & $1.14 \mathrm{E}-04$ & 14 & $3.28 \mathrm{E}-06$ & 6 & 2.93E-07 & 2 & $5.34 E-09$ & & & & & & & & \\
\hline 0.03 & 73 & 4.17E-04 & 21 & $2.23 \mathrm{E}-05$ & 9 & $3.11 \mathrm{E}-06$ & 4 & $1.05 \mathrm{E}-07$ & 1 & $1.22 \mathrm{E}-09$ & & & & & & \\
\hline 0.04 & 97 & $9.36 \mathrm{E}-04$ & 28 & 7.47E-05 & 13 & $1.40 \mathrm{E}-05$ & 5 & $7.12 \mathrm{E}-07$ & 2 & $1.35 \mathrm{E}-08$ & & & & & & \\
\hline 0.05 & 121 & $1.65 \mathrm{E}-03$ & 35 & $1.76 \mathrm{E}-04$ & 16 & 4.10E-05 & 6 & $2.81 \mathrm{E}-06$ & 2 & $7.64 \mathrm{E}-08$ & & & & & & \\
\hline 0.06 & 146 & $2.54 \mathrm{E}-03$ & 42 & $3.38 \mathrm{E}-04$ & 19 & $9.29 \mathrm{E}-05$ & 7 & $8.06 \mathrm{E}-06$ & 3 & $2.92 \mathrm{E}-07$ & & & & & & \\
\hline 0.08 & 194 & $4.69 \mathrm{E}-03$ & 56 & $8.69 \mathrm{E}-04$ & 25 & $3.05 \mathrm{E}-04$ & 10 & $3.76 \mathrm{E}-05$ & 3 & $2.09 \mathrm{E}-06$ & & & & & & \\
\hline 0.1 & 243 & $7.19 \mathrm{E}-03$ & 70 & $1.69 \mathrm{E}-03$ & 31 & 7.05E-04 & 12 & 1.12E-04 & 4 & $8.58 \mathrm{E}-06$ & 1 & $1.02 \mathrm{E}-06$ & & & & \\
\hline 0.2 & 485 & $2.14 \mathrm{E}-02$ & 140 & $9.37 \mathrm{E}-03$ & 63 & $6.24 \mathrm{E}-03$ & 24 & $2.00 \mathrm{E}-03$ & 9 & $3.66 \mathrm{E}-04$ & 2 & 1.15E-04 & 1 & $7.48 \mathrm{E}-05$ & & \\
\hline 0.3 & 728 & 3.53E-02 & 210 & $2.06 \mathrm{E}-02$ & 94 & $1.71 \mathrm{E}-02$ & 36 & $7.66 \mathrm{E}-03$ & 13 & $2.17 \mathrm{E}-03$ & 3 & $1.08 \mathrm{E}-03$ & 2 & $8.63 \mathrm{E}-04$ & & \\
\hline 0.4 & 971 & $4.76 \mathrm{E}-02$ & 280 & $3.33 \mathrm{E}-02$ & 126 & 3. $14 \mathrm{E}-02$ & 48 & $1.73 \mathrm{E}-02$ & 17 & $6.44 \mathrm{E}-03$ & 4 & $4.22 \mathrm{E}-03$ & 2 & $3.80 \mathrm{E}-03$ & 1 & $9.91 \mathrm{E}-03$ \\
\hline 0.5 & 1,214 & $5.86 \mathrm{E}-02$ & 350 & $4.62 \mathrm{E}-02$ & 157 & $4.76 \mathrm{E}-02$ & 61 & $3.03 \mathrm{E}-02$ & 22 & $1.36 \mathrm{E}-02$ & 6 & $1.07 \mathrm{E}-02$ & 3 & $1.05 \mathrm{E}-02$ & 2 & $2.55 \mathrm{E}-02$ \\
\hline 0.6 & 1,456 & $6.82 \mathrm{E}-02$ & 420 & $5.90 \mathrm{E}-02$ & 188 & $6.47 \mathrm{E}-02$ & 73 & $4.58 \mathrm{E}-02$ & 26 & $2.37 \mathrm{E}-02$ & 7 & $2.13 \mathrm{E}-02$ & 3 & $2.19 \mathrm{E}-02$ & 2 & $5.00 \mathrm{E}-02$ \\
\hline 0.8 & 1,942 & $8.46 \mathrm{E}-02$ & 560 & $8.30 \mathrm{E}-02$ & 251 & $9.94 \mathrm{E}-02$ & 97 & $8.13 E-02$ & 34 & $5.13 \mathrm{E}-02$ & 9 & $5.46 \mathrm{E}-02$ & 4 & $6.00 \mathrm{E}-02$ & 2 & $1.23 \mathrm{E}-01$ \\
\hline 1 & 2,427 & $9.81 \mathrm{E}-02$ & 700 & $1.05 \mathrm{E}-01$ & 314 & $1.33 \mathrm{E}-01$ & 121 & $1.20 \mathrm{E}-01$ & 43 & $8.60 \mathrm{E}-02$ & 11 & $1.02 \mathrm{E}-01$ & 5 & $1.15 \mathrm{E}-01$ & 3 & $2.16 \mathrm{E}-01$ \\
\hline 2 & 4,854 & $1.41 \mathrm{E}-01$ & 1,400 & $1.86 \mathrm{E}-01$ & 628 & $2.67 \mathrm{E}-01$ & 242 & $2.96 \mathrm{E}-01$ & 86 & $2.86 \mathrm{E}-01$ & 22 & $3.95 \mathrm{E}-01$ & 10 & $4.60 \mathrm{E}-01$ & 6 & $6.47 \mathrm{E}-01$ \\
\hline 3 & 7,281 & $1.66 \mathrm{E}-01$ & 2,100 & $2.38 \mathrm{E}-01$ & 942 & $3.57 \mathrm{E}-01$ & 363 & $4.26 \mathrm{E}-01$ & 129 & $4.53 \mathrm{E}-01$ & 33 & $6.23 \mathrm{E}-01$ & 15 & $7.05 \mathrm{E}-01$ & 9 & $8.54 \mathrm{E}-01$ \\
\hline 4 & 9,708 & $1.83 \mathrm{E}-01$ & 2,800 & $2.76 \mathrm{E}-01$ & 1,256 & $4.21 \mathrm{E}-01$ & 484 & $5.19 \mathrm{E}-01$ & 172 & $5.75 \mathrm{E}-01$ & 44 & $7.64 \mathrm{E}-01$ & 20 & $8.38 \mathrm{E}-01$ & 12 & 9.37 E-01 \\
\hline 6 & 14,562 & $2.05 \mathrm{E}-01$ & 4,200 & $3.27 \mathrm{E}-01$ & 1,884 & $5.06 \mathrm{E}-01$ & 726 & $6.40 \mathrm{E}-01$ & 258 & $7.29 \mathrm{E}-01$ & 66 & $9.01 \mathrm{E}-01$ & 30 & $9.47 \mathrm{E}-01$ & 18 & $9.86 \mathrm{E},-01$ \\
\hline 8 & 19.416 & $2.20 \mathrm{E}-01$ & 5,600 & $3.61 \mathrm{E}-01$ & 2,512 & $5.62 \mathrm{E}-01$ & 968 & 7.14E-0I & 344 & $8.14 \mathrm{E}-01$ & 88 & $9.54 \mathrm{E}-01$ & 40 & $9.80 \mathrm{E}-01$ & 24 & $9.96 \mathrm{E}-01$ \\
\hline 10 & 24,270 & $2.30 \mathrm{E}-01$ & 7,000 & $3.86 \mathrm{E}-01$ & 3,140 & $6.01 \mathrm{E}-01$ & 1,210 & $7.63 \mathrm{E}-01$ & 430 & $8.66 \mathrm{E}-01$ & 110 & $9.77 \mathrm{E}-01$ & 50 & $9.92 \mathrm{E}-01$ & 30 & $9.99 \mathrm{E}-01$ \\
\hline
\end{tabular}

a Allowable cycles obtained from the NUREG/CR-5999 interim design curves 
Table A-5. Allowable cycles ${ }^{a}$ and probability of fatigue cracking in austenitic stainless steel components in water as a function of cumulative usage factor at different applied stress amplitudes

\begin{tabular}{|c|c|c|c|c|c|c|c|c|c|c|c|c|c|c|c|c|}
\hline \multirow{2}{*}{$\frac{\text { CUF }}{0.01}$} & \multicolumn{2}{|c|}{$28.0 \mathrm{ksi}$} & \multicolumn{2}{|c|}{$40.0 \mathrm{ksi}$} & \multicolumn{2}{|c|}{$45.0 \mathrm{ksl}$} & \multicolumn{2}{|c|}{$55.0 \mathrm{ksi}$} & \multicolumn{2}{|c|}{$62.0 \mathrm{ksi}$} & \multicolumn{2}{|c|}{$70.0 \mathrm{ksi}$} & \multicolumn{2}{|c|}{$110.0 \mathrm{ksi}$} & \multicolumn{2}{|c|}{$160.0 \mathrm{ksi}$} \\
\hline & 1,016 & $1.98 \mathrm{E}-04$ & 98 & $3.27 \mathrm{E}-08$ & 48 & $5.96 \mathrm{E}-10$ & 14 & $1.03 \mathrm{E}-13$ & 7 & $2.22 \mathrm{E}-16$ & & & & & & \\
\hline 0.02 & 2,031 & $1.78 \mathrm{E}-03$ & 195 & $2.72 \mathrm{E}-06$ & 96 & $1.17 \mathrm{E}-07$ & 29 & $1.03 \mathrm{E}-10$ & 14 & $5.14 \mathrm{E}-13$ & 9 & $5.48 \mathrm{E}-14$ & 3 & $5.55 \mathrm{E}-16$ & & \\
\hline 0.03 & 3,047 & $4.99 \mathrm{E}-03$ & 293 & $2.41 \mathrm{E}-05$ & 144 & $1.64 \mathrm{E}-06$ & 43 & $3.51 \mathrm{E}-09$ & 21 & $3.15 \mathrm{E}-11$ & 14 & $4.48 \mathrm{E}-12$ & 5 & $9.56 \mathrm{E}-14$ & & \\
\hline 0.04 & 4,063 & $9.40 \mathrm{E}-03$ & 391 & $9.58 \mathrm{E}-05$ & 192 & $8.82 \mathrm{E}-06$ & 57 & $3.45 \mathrm{E}-08$ & 28 & $4.63 \mathrm{E}-10$ & 19 & $7.99 \mathrm{E}-11$ & 6 & $2.73 \mathrm{E}-12$ & 2 & $1.22 \mathrm{E}-15$ \\
\hline 0.05 & 5,078 & $1.46 \mathrm{E}-02$ & 488 & $2.55 \mathrm{E}-04$ & 240 & $2.93 E-05$ & 72 & $1.80 \mathrm{E}-07$ & 35 & $3.27 \mathrm{E}-09$ & 24 & $6.52 \mathrm{E}-10$ & 8 & $3.16 \mathrm{E}-11$ & 2 & $2.45 E-14$ \\
\hline 0.06 & 6,094 & $2.02 \mathrm{E}-02$ & 586 & $5.34 \mathrm{E}-04$ & 288 & $7.34 \mathrm{E}-05$ & 86 & $6.41 \mathrm{E}-07$ & 42 & $1.48 \mathrm{E}-08$ & 28 & $3.32 \mathrm{E}-09$ & 10 & $2.11 \mathrm{E}-10$ & 3 & $2.45 \mathrm{E}-13$ \\
\hline 0.08 & 8,125 & $3.22 \mathrm{E}-02$ & 781 & $1.56 \mathrm{E}-03$ & 385 & $2.78 \mathrm{E}-04$ & 115 & $4.15 \mathrm{E}-06$ & 56 & $1.39 \mathrm{E}-07$ & 38 & $3.70 \mathrm{E}-08$ & 13 & $3.56 \mathrm{E}-09$ & 4 & $7.68 \mathrm{E}-12$ \\
\hline 0.1 & 10,157 & $4.43 \mathrm{E}-02$ & 977 & $3.28 \mathrm{E}-03$ & 481 & $7.12 \mathrm{E}-04$ & 144 & $1.58 \mathrm{E}-05$ & 70 & $6.94 \mathrm{E}-07$ & 47 & $2.11 \mathrm{E}-07$ & 16 & $2.74 \mathrm{E}-08$ & 5 & $9.41 \mathrm{E}-11$ \\
\hline 0.2 & 20,314 & $9.84 \mathrm{E}-02$ & 1,953 & $2.22 \mathrm{E}-02$ & 961 & $8.10 \mathrm{E}-03$ & 287 & $5.46 \mathrm{E}-04$ & 140 & $5.31 \mathrm{E}-05$ & 95 & $2.33 \mathrm{E}-05$ & 32 & $6.94 \mathrm{E}-06$ & 9 & $9.31 \mathrm{E}-08$ \\
\hline 0.3 & 30,470 & $1.40 \mathrm{E}-01$ & 2,930 & $5.24 \mathrm{E}-02$ & 1,442 & $2.46 \mathrm{E}-02$ & 431 & $2.92 \mathrm{E}-03$ & 210 & $4.30 \mathrm{E}-04$ & 142 & $2.28 \mathrm{E}-04$ & 48 & $1.02 \mathrm{E}-04$ & 14 & $2.83 \mathrm{E}-06$ \\
\hline 0.4 & 40,627 & $1.72 \mathrm{E}-01$ & 3,907 & $8.71 E-02$ & 1,923 & $4.78 \mathrm{E}-02$ & 575 & $8.12 \mathrm{E}-03$ & 280 & $1.57 \mathrm{E}-03$ & 190 & $9.37 \mathrm{E}-04$ & 64 & $5.39 \mathrm{E}-04$ & 18 & $2.44 \mathrm{E}-05$ \\
\hline 0.5 & 50,784 & $1.98 \mathrm{E}-01$ & 4,884 & $1.23 \mathrm{E}-01$ & 2,404 & $7.49 \mathrm{E}-02$ & 719 & $1.64 \mathrm{E}-02$ & 350 & $3.87 \mathrm{E}-03$ & 237 & $2.52 \mathrm{E}-03$ & 80 & $1.72 \mathrm{E}-03$ & 23 & $1.11 \mathrm{E}-04$ \\
\hline 0.6 & 60,941 & $2.20 \mathrm{E}-01$ & 5,860 & $1.57 \mathrm{E}-01$ & 2,884 & $1.04 \mathrm{E}-01$ & 862 & $2.76 \mathrm{E}-02$ & 419 & $7.58 \mathrm{E}-03$ & 284 & $5.26 \mathrm{E}-03$ & 96 & $4.07 \mathrm{E}-03$ & 27 & $3.48 \mathrm{E}-04$ \\
\hline 0.8 & 81,254 & $2.54 \mathrm{E}-01$ & 7,814 & $2.21 \mathrm{E}-01$ & 3,846 & $1.63 \mathrm{E}-01$ & 1,150 & $5.70 \mathrm{E}-02$ & 559 & $1.96 \mathrm{E}-02$ & 379 & $1.49 \mathrm{E}-02$ & 128 & $1.37 \mathrm{E}-02$ & 36 & $1.76 \mathrm{E}-03$ \\
\hline 1 & 101,568 & $2.80 \mathrm{E}-01$ & 9,767 & $2.77 \mathrm{E}-01$ & 4,807 & $2.20 \mathrm{E}-01$ & 1.437 & $9.26 \mathrm{E}-02$ & 699 & $3.73 \mathrm{E}-02$ & 474 & $3.02 \mathrm{E}-02$ & 160 & $3.09 \mathrm{E}-02$ & 45 & $5.37 \mathrm{E}-03$ \\
\hline 2 & 203,136 & $3.54 \mathrm{E}-01$ & 19,534 & $4.66 \mathrm{E}-01$ & 9,614 & $4.34 \mathrm{E}-01$ & 2,874 & $2.88 \mathrm{E}-01$ & 1,398 & $1.74 \mathrm{E}-01$ & 948 & $1.63 \mathrm{E}-01$ & 320 & $2.04 \mathrm{E}-0 \mathrm{I}$ & 90 & $7.80 \mathrm{E}-02$ \\
\hline 3 & 304,704 & $3.92 \mathrm{E}-01$ & 29,301 & $5.72 \mathrm{E}-01$ & 14,421 & $5.64 \mathrm{E}-01$ & 4,311 & $4.46 \mathrm{E}-01$ & 2,097 & $3.21 \mathrm{E}-01$ & 1,422 & $3.18 \mathrm{E}-01$ & 480 & $4.11 \mathrm{E}-01$ & 135 & $2.24 \mathrm{E}-01$ \\
\hline 4 & 406,272 & $4.17 \mathrm{E}-01$ & 39,068 & $6.39 \mathrm{E}-01$ & 19,228 & $6.48 \mathrm{E}-01$ & 5,748 & 5.61E-01 & 2,796 & $4.45 \mathrm{E}-01$ & 1,896 & $4.52 \mathrm{E}-01$ & 640 & $5.78 \mathrm{E}-01$ & 180 & $3.84 \mathrm{E}-01$ \\
\hline 6 & 609,408 & $4.47 \mathrm{E}-01$ & 58,602 & $7.19 \mathrm{E}-01$ & 28,842 & $7.48 \mathrm{E}-01$ & 8,622 & $7.08 \mathrm{E}-01$ & 4,194 & $6.22 \mathrm{E}-01$ & 2,844 & $6.42 \mathrm{E}-01$ & 960 & $7.84 \mathrm{E}-01$ & 270 & $6.40 \mathrm{E}-01$ \\
\hline 8 & 812,544 & $4.66 \mathrm{E}-01$ & 78,136 & $7.67 \mathrm{E}-01$ & 38,456 & $8.05 \mathrm{E}-01$ & 11,496 & $7.92 \mathrm{E}-01$ & 5,592 & 7.32E-01 & 3,792 & $7.58 \mathrm{E}-01$ & 1,280 & $8.85 \mathrm{E},-01$ & 360 & $7.94 \mathrm{E}-01$ \\
\hline 10 & 015,680 & $4.79 \mathrm{E}-01$ & 97,670 & $7.98 \mathrm{E}-01$ & 48,070 & $8.41 \mathrm{E}-01$ & 14,370 & $8.45 \mathrm{E}-01$ & 6,990 & $8.03 \mathrm{E}-01$ & 4,740 & $8.30 \mathrm{E}-01$ & 1,600 & $9.36 \mathrm{E}-01$ & 450 & $8.80 \mathrm{E}-01$ \\
\hline
\end{tabular}




\begin{tabular}{|c|c|c|c|c|c|c|c|c|c|c|c|c|c|c|c|c|}
\hline \multirow{2}{*}{$\frac{\text { CUF }}{0.01}$} & \multicolumn{2}{|c|}{$28.0 \mathrm{ksi}$} & \multicolumn{2}{|c|}{$40.0 \mathrm{ksi}$} & \multicolumn{2}{|c|}{$45.0 \mathrm{ksi}$} & \multicolumn{2}{|c|}{$55.0 \mathrm{ksi}$} & \multicolumn{2}{|c|}{$62.0 \mathrm{ksi}$} & \multicolumn{2}{|c|}{$70.0 \mathrm{ksi}$} & \multicolumn{2}{|c|}{$110.0 \mathrm{ksi}$} & \multicolumn{2}{|c|}{$160.0 \mathrm{ksi}$} \\
\hline & 1,016 & $2.85 \mathrm{E}-07$ & 98 & $9.98 \mathrm{E}-14$ & 48 & $2.22 \mathrm{E}-16$ & & & & & & & & & & \\
\hline 0.02 & 2,031 & $9.78 \mathrm{E}-06$ & 195 & $6.91 \mathrm{E}-11$ & 96 & $3.44 \mathrm{E}-13$ & & & & & & & & & & \\
\hline 0.03 & 3,047 & $5.45 \mathrm{E}-05$ & 293 & $1.94 \mathrm{E}-09$ & 144 & $1.75 \mathrm{E}-11$ & 43 & $6.66 \mathrm{E}-16$ & & & & & & & & \\
\hline 0.04 & 4,063 & $1.60 \mathrm{E}-04$ & 391 & $1.68 \mathrm{E}-08$ & 192 & $2.27 \mathrm{E}-10$ & 57 & $1.93 \mathrm{E}-14$ & & & & & & & & \\
\hline 0.05 & 5,078 & $3.42 \mathrm{E}-04$ & 488 & $8.01 \mathrm{E}-08$ & 240 & $1.46 \mathrm{E}-09$ & 72 & $2.20 \mathrm{E}-13$ & 35 & $3.33 \mathrm{E}-16$ & & & & & & \\
\hline 0.06 & 6,094 & $6.06 \mathrm{E}-04$ & 586 & $2.66 \mathrm{E}-07$ & 288 & $6.18 \mathrm{E}-09$ & 86 & 1. $47 \mathrm{E}-12$ & 42 & $2.89 \mathrm{E}-15$ & 28 & $1.11 \mathrm{E}-16$ & & & & \\
\hline 0.08 & 8,125 & $1.38 \mathrm{E}-03$ & 781 & $1.56 \mathrm{E}-06$ & 385 & $5.22 \mathrm{E}-08$ & 115 & $2.50 \mathrm{E}-11$ & 56 & $7.69 \mathrm{E}-14$ & 38 & $5.44 \mathrm{E}-15$ & & & & \\
\hline 0.1 & 10,157 & $2.45 \mathrm{E}-03$ & 977 & $5.50 \mathrm{E}-06$ & 481 & $2.43 E-07$ & 144 & $1.98 \mathrm{E}-10$ & 70 & $8.60 \mathrm{E}-13$ & 47 & $7.27 \mathrm{E}-14$ & 16 & $2.22 \mathrm{E}-16$ & & \\
\hline 0.2 & 20,314 & $1.07 \mathrm{E}-02$ & 1,953 & $1.60 \mathrm{E}-04$ & 961 & $1.55 \mathrm{E}-05$ & 287 & $5.92 \mathrm{E}-08$ & 140 & $7.21 \mathrm{E}-10$ & 95 & $1.03 \mathrm{E}-10$ & 32 & $1.33 \mathrm{E}-12$ & 9 & $2.22 \mathrm{E}-16$ \\
\hline 0.3 & 30,470 & $2.07 \mathrm{E}-02$ & 2,930 & $8.02 \mathrm{E}-04$ & 1,442 & $1.17 \mathrm{E}-04$ & 431 & $1.03 \mathrm{E}-06$ & 210 & $2.20 \mathrm{E}-08$ & 142 & 4.16E-09 & 48 & $1.10 \mathrm{E}-10$ & 14 & $4.21 \mathrm{E}-14$ \\
\hline 0.4 & 40,627 & $3.10 \mathrm{E}-02$ & 3,907 & $2.17 \mathrm{E}-03$ & 1,923 & $4.14 \mathrm{E}-04$ & 575 & $6.31 \mathrm{E}-06$ & 280 & $1.98 \mathrm{E}-07$ & 190 & $4.55 \mathrm{E}-08$ & 64 & $1.94 \mathrm{E}-09$ & 18 & $1.48 \mathrm{E}-12$ \\
\hline 0.5 & 50,784 & 4.07E-02 & 4,884 & $4.34 \mathrm{E}-03$ & 2,404 & $1.01 \mathrm{E}-03$ & 719 & $2.31 \mathrm{E}-05$ & 350 & $9.65 \mathrm{E}-07$ & 237 & $2.55 \mathrm{E}-07$ & 80 & 1.55E-08 & 23 & $1.99 \mathrm{E}-11$ \\
\hline 0.6 & 60,941 & $4.98 \mathrm{E}-02$ & 5,860 & $7.29 \mathrm{E}-03$ & 2,884 & $1.96 \mathrm{E}-03$ & 862 & $6.19 \mathrm{E}-05$ & 419 & $3.25 \mathrm{E}-06$ & 284 & $9.58 \mathrm{E}-07$ & 96 & $7.69 \mathrm{E}-08$ & 27 & $1.49 \mathrm{E}-10$ \\
\hline 0.8 & 81,254 & $6.61 \mathrm{E}-02$ & 7,814 & $1.52 \mathrm{E}-02$ & 3,846 & $5.10 \mathrm{E}-03$ & 1,150 & $2.59 \mathrm{E}-04$ & 559 & $1.91 \mathrm{E}-05$ & 379 & $6.67 \mathrm{E}-06$ & 128 & $8.09 \mathrm{E}-07$ & 36 & $2.97 \mathrm{E}-09$ \\
\hline 1 & 101,568 & $8.00 \mathrm{E}-02$ & 9,767 & $2.52 \mathrm{E}-02$ & 4,807 & $9.87 E-03$ & 1,437 & $7.07 \mathrm{E}-04$ & 699 & $6.73 \mathrm{E}-05$ & 474 & $2.66 \mathrm{E}-05$ & 160 & $4.35 \mathrm{E}-06$ & 45 & $2.57 \mathrm{E}-08$ \\
\hline 2 & 203,136 & $1.28 \mathrm{E}-01$ & 19,534 & $8.75 \mathrm{E}-02$ & 9,614 & $5.14 \mathrm{E}-02$ & 2,874 & $9.39 \mathrm{E}-03$ & 1,398 & $1.82 \mathrm{E}-03$ & 948 & $1.01 \mathrm{E}-03$ & 320 & $3.71 \mathrm{E}-04$ & 90 & $8.71 \mathrm{E}-06$ \\
\hline 3 & 304,704 & 1.57E-01 & 29,301 & $1.50 \mathrm{E}-01$ & 14,421 & $1.05 \mathrm{E}-01$ & 4,311 & $3.01 \mathrm{E}-02$ & 2,097 & $8.36 \mathrm{E}-03$ & 1,422 & $5.48 \mathrm{E}-03$ & 480 & $2.95 \mathrm{E}-03$ & 135 & $1.44 \mathrm{E}-04$ \\
\hline 4 & 406,272 & $1.77 \mathrm{E}-01$ & 39,068 & $2.04 \mathrm{E}-01$ & 19,228 & $1.60 \mathrm{E}-01$ & 5,748 & $6.00 \mathrm{E}-02$ & 2,796 & $2.09 \mathrm{E}-02$ & 1,896 & $1.52 \mathrm{E}-02$ & 640 & $1.03 \mathrm{E}-02$ & 180 & $8.08 \mathrm{E}-04$ \\
\hline 6 & 609,408 & $2.03 E-01$ & 58,602 & $2.91 E-01$ & 28,842 & $2.56 \mathrm{E}-01$ & 8,622 & $1.33 \mathrm{E}-01$ & 4,194 & $6.13 \mathrm{E}-02$ & 2,844 & $5.03 \mathrm{E}-02$ & 960 & $4.40 \mathrm{E}-02$ & 270 & $6.41 \mathrm{E}-03$ \\
\hline 8 & 812,544 & $2.20 \mathrm{E}-01$ & 78,136 & $3.55 \mathrm{E}-01$ & 38,456 & $3.34 \mathrm{E}-01$ & 11,496 & $2.08 \mathrm{E}-01$ & 5,592 & $1.14 \mathrm{E}-01$ & 3,792 & $1.00 \mathrm{E}-01$ & 1,280 & $1.01 \mathrm{E}-01$ & 360 & $2.17 \mathrm{E}-02$ \\
\hline 10 & 015,680 & $2.32 \mathrm{E}-01$ & 97,670 & $4.05 \mathrm{E}-01$ & 48,070 & $3.97 \mathrm{E}-01$ & 14,370 & $2.79 \mathrm{E}-01$ & 6,990 & $1.72 \mathrm{E}-01$ & 4,740 & $1.58 \mathrm{E}-01$ & 1,600 & $1.72 \mathrm{E}-01$ & 450 & $4.88 \mathrm{E}-\mathrm{O} 2$ \\
\hline
\end{tabular}


Table A-7. Inverse of standard cumulative distribution function

\begin{tabular}{cccccc}
\hline Probability & $\mathrm{F}^{-1}[\mathrm{x}]$ & $\mathrm{F}^{-1}[1-\mathrm{x}]$ & Probability & $\mathrm{F}^{-1}[\mathrm{x}]$ & $\mathrm{F}^{-1}[1-\mathrm{x}]$ \\
\hline 0.01 & -3.7195 & 3.7195 & 3.00 & -1.8808 & 1.8808 \\
0.02 & -3.5402 & 3.5402 & 5.00 & -1.6449 & 1.6449 \\
0.03 & -3.4319 & 3.4319 & 7.00 & -1.4758 & 1.4758 \\
0.05 & -3.2905 & 3.2905 & 10.00 & -1.2816 & 1.2816 \\
0.07 & -3.1947 & 3.1947 & 20.00 & -0.8416 & 0.8416 \\
0.10 & -3.0902 & 3.0902 & 30.00 & -0.5244 & 0.5244 \\
0.20 & -2.8782 & 2.8782 & 50.00 & 0.0000 & 0.0000 \\
0.30 & -2.7478 & 2.7478 & 65.00 & 0.3853 & -0.3853 \\
0.50 & -2.5758 & 2.5758 & 80.00 & 0.8416 & -0.8416 \\
0.70 & -2.4573 & 2.4573 & 90.00 & 1.2816 & -1.2816 \\
1.00 & -2.3263 & 2.3263 & 95.00 & 1.6449 & -1.6449 \\
2.00 & -2.0537 & 2.0537 & 98.00 & 2.0537 & -2.0537 \\
\hline
\end{tabular}

Table A-8. Fatigue evaluation for SA-508 Class 2 low-alloy steel inlet nozzle of PWR vessel (Fatigue data from Table 5.3, NUREG/CR-6260)

\begin{tabular}{cccc}
\hline $\begin{array}{c}\text { Stress } \\
\text { Amplitude (ksi) }\end{array}$ & $\begin{array}{c}\text { Applied } \\
\text { Cycles }\end{array}$ & $\begin{array}{c}\text { NUREG/CR-5999 } \\
\text { Design Life }\end{array}$ & $\begin{array}{c}\text { Usage } \\
\text { Factor }\end{array}$ \\
\hline 60.47 & 200 & 869 & 0.230 \\
48.01 & 300 & 1928 & 0.156 \\
36.96 & 180 & 5382 & 0.033 \\
36.46 & 320 & 5676 & 0.056 \\
\cline { 2 - 3 } & & Cumulative Usage Factor: & 0.475 \\
\hline & Probability of Fatigue Cracking at max. stress 60 ksi): & $2.9 \times 10^{-3}$ \\
& Probability of Fatigue Cracking (at mid stress 54 ksi): & $4.8 \times 10^{-3}$ \\
& Probability of Fatigue Cracking (at min. stress 48 ksi): & $1.0 \times 10^{-2}$ \\
\hline
\end{tabular}

a Max., mid, and min. values represent the stress range where $>80$ of fatigue usage is accumulated.

Table A-9. Fatigue evaluation for SA-508 Class 2 low-alloy steel outlet nozzle of PWR vessel (Fatigue data from Table 5.5, NUREG/CR-6260)

\begin{tabular}{cccl}
\hline $\begin{array}{c}\text { Stress } \\
\text { Amplitude (ksi) }\end{array}$ & $\begin{array}{c}\text { Applied } \\
\text { Cycles }\end{array}$ & $\begin{array}{c}\text { NUREG/CR-5999 } \\
\text { Design Life }\end{array}$ & $\begin{array}{l}\text { Usage } \\
\text { Factor }\end{array}$ \\
\hline 51.51 & 90 & 1458 & 0.062 \\
50.85 & 200 & 1534 & 0.130 \\
39.24 & 90 & 4263 & 0.021 \\
20.84 & 14620 & 58406 & 0.25 \\
19.82 & 480 & 73899 & 0.007 \\
& & Cumulative Usage Factor: & 0.472 \\
\hline & Probability of Fatigue Cracking (at max. stress 51 ksi): & $6.6 \times 10^{-3}$ \\
& Probability of Fatigue Cracking (at mid stress 36 ksi): & $3.8 \times 10^{-2}$ \\
Probability of Fatigue Cracking (at min. stress 21 ksi): & $9.2 \times 10^{-2}$ \\
\hline
\end{tabular}

a Max., mid, and min. values represent the stress range where $>80$ of fatigue usage is accumulated. 
Table A-10. Fatigue evaluation for Type 316 stainless steel surge line of a PWR (Fatigue data from Table 5.7, NUREG/CR-6260)

\begin{tabular}{|c|c|c|c|}
\hline $\begin{array}{c}\text { Stress } \\
\text { Amplitude (ksi) }\end{array}$ & $\begin{array}{l}\text { Applied } \\
\text { Cycles }\end{array}$ & $\begin{array}{l}\text { NUREG/CR-5999 } \\
\text { Design Life }\end{array}$ & $\begin{array}{l}\text { Usage } \\
\text { Factor }\end{array}$ \\
\hline 190.17 & 6 & 43 & 0.140 \\
\hline 163.18 & 14 & 62 & 0.226 \\
\hline 162.06 & 14 & 63 & 0.222 \\
\hline 138.05 & 4 & 92 & 0.043 \\
\hline 127.94 & 14 & 111 & 0.126 \\
\hline 127.04 & 10 & 113 & 0.088 \\
\hline 64.76 & 68 & 571 & 0.119 \\
\hline 64.17 & 68 & 584 & 0.116 \\
\hline 63.39 & 68 & 611 & 0.111 \\
\hline 63.38 & 68 & 611 & 0.111 \\
\hline 54.02 & 1248 & 1600 & 0.780 \\
\hline 52.38 & 23 & 1921 & 0.011 \\
\hline 52.35 & 23 & 1933 & 0.011 \\
\hline 52.35 & 27 & 1933 & 0.014 \\
\hline 52.26 & 6 & 1953 & 0.003 \\
\hline 52.26 & 109 & 1953 & 0.056 \\
\hline 51.76 & 63 & 2070 & 0.030 \\
\hline 51.24 & 40 & 2200 & 0.018 \\
\hline 51.18 & 30 & 2215 & 0.014 \\
\hline 50.96 & 9 & 2273 & 0.004 \\
\hline 40.10 & 90 & 9620 & 0.009 \\
\hline 40.09 & 90 & 9635 & 0.009 \\
\hline 39.91 & 81 & 9899 & 0.008 \\
\hline 39.03 & 81 & 11321 & 0.007 \\
\hline 38.94 & 90 & 11480 & 0.008 \\
\hline 38.82 & 30 & 11695 & 0.003 \\
\hline 33.10 & 3670 & 30525 & 0.120 \\
\hline 33.10 & 4120 & 30525 & 0.135 \\
\hline 33.10 & 200 & 30525 & 0.007 \\
\hline 33.10 & 4580 & 30525 & 0.150 \\
\hline 32.87 & 70 & 31834 & 0.002 \\
\hline 29.90 & 9400 & 56289 & 0.167 \\
\hline 29.90 & 17040 & 56289 & 0.303 \\
\hline \multirow[t]{2}{*}{29.90} & 17040 & 56289 & 0.303 \\
\hline & & Cumulative Usage Factor: & 3.476 \\
\hline \multirow{2}{*}{\multicolumn{3}{|c|}{ Probability of Fatigue Cracking (at max. stress $190 \mathrm{ksi}$ ): }} & $5.3 \times 10^{-1}$ \\
\hline \multirow{2}{*}{\multicolumn{3}{|c|}{$\begin{array}{l}\text { Probability of Fatigue Cracking (at mid stress } 54 \mathrm{ksi} \text { ): } \\
\text { Probability of Fatigue Cracking (at min. stress } 30 \mathrm{ksi} \text { ): }\end{array}$}} & $5.2 \times 10^{-1}$ \\
\hline & & & $4.5 \times 10^{-1}$ \\
\hline
\end{tabular}

a Max., mid, and min. values represent the stress range where $>80$ of fatigue usage is accumulated. 
Table A-11. Fatigue evaluation for Type 316 stainless steel safe end for safety injection nozzle of a PWR (Fatigue data from Table 5.17, NUREG/CR-6260)

\begin{tabular}{cccc}
\hline $\begin{array}{c}\text { Stress } \\
\text { Amplitude (ksi) }\end{array}$ & $\begin{array}{c}\text { Applied } \\
\text { Cycles }\end{array}$ & $\begin{array}{c}\text { NUREG/CR-5999 } \\
\text { Design Life }\end{array}$ & $\begin{array}{c}\text { Usage } \\
\text { Factor }\end{array}$ \\
\hline 121.67 & 260 & 125 & 2.080 \\
72.08 & 500 & 441 & 1.134 \\
\cline { 3 - 4 } & & Cumulative Usage Factor: & 3.215 \\
\hline & Probability of Fatigue Cracking (at max. stress 122 ksi): & $4.7 \times 10^{-1}$ \\
Probability of Fatigue Cracking (at mid stress 97 ksi): & $4.3 \times 10^{-1}$ \\
Probability of Fatigue Cracking (at min. stress 72 ksi): & $3.6 \times 10^{-1}$ \\
\hline
\end{tabular}

a Max., mid, and min. values represent the stress range where $>80$ of fatigue usage is accumulated.

Table A-12. Fatigue evaluation for Type 316 stainless steel reducing tee from decay heat removal system of a PWR (Fatigue data from Table 5.59, NUREG/CR-6260)

\begin{tabular}{cccc}
\hline $\begin{array}{c}\text { Stress } \\
\text { Amplitude (ksi) }\end{array}$ & $\begin{array}{c}\text { Applied } \\
\text { Cycles }\end{array}$ & $\begin{array}{c}\text { NUREG/CR-5999 } \\
\text { Design Life }\end{array}$ & Usage \\
Factor \\
\hline 261.76 & 30 & 20 & 1.5 \\
261.76 & 30 & 20 & 1.5 \\
218.69 & 40 & 30 & 1.333 \\
196.62 & 160 & 39 & 4.103 \\
196.50 & 220 & 39 & 5.641 \\
57.11 & 20 & 1145 & 0.017 \\
45.95 & 80 & 4239 & 0.019 \\
44.35 & 480 & 5246 & 0.091 \\
39.77 & 40 & 10111 & 0.004 \\
& & Cumulative Usage Factor: & 14.209 \\
\hline & Probability of Fatigue Cracking (at max. stress 262 ksi): & $9.9 \times 10^{-1}$ \\
Probability of Fatigue Cracking (at mid stress 230 ksi): & $9.9 \times 10^{-1}$ \\
Probability of Fatigue Cracking (at min. stress 197 ksi): & $9.9 \times 10^{-1}$ \\
\hline
\end{tabular}

a Max., mid, and min. values represent the stress range where $>80$ of fatigue usage is accumulated.

Table A-13. Fatigue evaluation for Alloy 600 instrumentation penetration weld of PWR lower head (Fatigue data from Table 5.46, NUREG/CR-6260)

\begin{tabular}{cccc}
\hline $\begin{array}{c}\text { Stress } \\
\text { Amplitude (ksi) }\end{array}$ & $\begin{array}{c}\text { Applied } \\
\text { Cycles }\end{array}$ & $\begin{array}{c}\text { NUREG/CR-5999 } \\
\text { Design Life }\end{array}$ & $\begin{array}{c}\text { Usage } \\
\text { Factor }\end{array}$ \\
\hline 68.96 & 720 & 491 & 1.466 \\
& & Cumulative Usage Factor: & 1.466 \\
\hline & & Probability of Fatigue Cracking (at 69 ksi): & $2.3 \times 10^{-4}$ \\
\hline
\end{tabular}


Table A-14. Fatigue evaluation for SA-333 Grade 6 carbon steel piping for residual heat removal suction line of a BWR (Fatigue data from Table 5.125, NUREG/CR-6260)

\begin{tabular}{|c|c|c|c|}
\hline $\begin{array}{c}\text { Stress } \\
\text { Amplitude (ksi) }\end{array}$ & $\begin{array}{l}\text { Applied } \\
\text { Cycles }\end{array}$ & $\begin{array}{c}\text { NUREG/CR-5999 } \\
\text { Design Life } \\
\end{array}$ & $\begin{array}{l}\text { Usage } \\
\text { Factor }\end{array}$ \\
\hline 46.93 & 5 & 102 & 0.049 \\
\hline 46.84 & 114 & 103 & 1.107 \\
\hline 24.73 & 152 & 1430 & 0.106 \\
\hline 23.78 & 11976 & 1780 & 6.728 \\
\hline 23.24 & 523 & 2025 & 0.258 \\
\hline 23.14 & 610 & 2074 & 0.294 \\
\hline 22.97 & 1620 & 2161 & 0.750 \\
\hline 16.68 & 10480 & 7565 & 1.385 \\
\hline 16.21 & 242 & 8359 & 0.029 \\
\hline 15.81 & 360 & 9127 & 0.039 \\
\hline 15.74 & 300 & 9271 & 0.032 \\
\hline 15.37 & 619 & 10080 & 0.061 \\
\hline \multirow[t]{2}{*}{8.21} & $3.0 \times 10^{6}$ & $7.1 \times 10^{6}$ & 0.422 \\
\hline & & Cumulative Usage Factor: & 11.260 \\
\hline \multicolumn{3}{|c|}{$\begin{array}{l}\text { Probability of Fatigue Cracking (at max. stress } 47 \mathrm{ksi} \text { ): } \\
\text { Probability of Fatigue Cracking (at mid stress } 32 \mathrm{ksi} \text { ): } \\
\text { Probability of Fatigue Cracking (at min. stress } 17 \mathrm{ksi} \text { ): }\end{array}$} & $\begin{array}{l}8.2 \times 10^{-1} \\
5.4 \times 10^{-1} \\
9.3 \times 10^{-2}\end{array}$ \\
\hline
\end{tabular}

a Max., mid, and min. values represent the stress range where $>80$ of fatigue usage is accumulated. 
Table A-15. Fatigue evaluation for SA-333 Grade 6 carbon steel elbow from BWR feedwater line piping (Fatigue data from Table 5.123, NUREG/CR-6260)

\begin{tabular}{|c|c|c|c|c|c|}
\hline $\begin{array}{c}\text { Stress } \\
\text { Amplitude (ksi) }\end{array}$ & $\begin{array}{c}\text { Temperature } \\
{ }^{\circ} \mathrm{C} \\
\end{array}$ & $\begin{array}{c}\text { Strain Rate } \\
/ \mathrm{s}\end{array}$ & $\begin{array}{l}\text { Applied } \\
\text { Cycles }\end{array}$ & $\begin{array}{c}\text { NUREG/CR- } \\
\text { 5999 Design Life }\end{array}$ & $\begin{array}{l}\text { Usage } \\
\text { Factor }\end{array}$ \\
\hline 106.04 & 200 & 0.117 & 5 & 199 & 0.025 \\
\hline 103.96 & 200 & 0.114 & 5 & 206 & 0.024 \\
\hline 102.61 & 200 & 0.113 & 5 & 211 & 0.024 \\
\hline 91.59 & 200 & 0.001 & 8 & 65 & 0.123 \\
\hline 89.40 & 200 & 0.095 & 10 & 271 & 0.037 \\
\hline 88.27 & 200 & 0.094 & 5 & 278 & 0.018 \\
\hline 83.76 & 200 & 0.041 & 126 & 243 & 0.519 \\
\hline 81.43 & 215 & 0.086 & 10 & 300 & 0.033 \\
\hline 67.93 & 200 & 0.001 & 97 & 131 & 0.740 \\
\hline 66.71 & 200 & 0.001 & 14 & 138 & 0.101 \\
\hline 61.29 & 200 & 0.001 & 6 & 173 & 0.035 \\
\hline 61.16 & 212 & 0.001 & 64 & 142 & 0.451 \\
\hline 55.5 & 200 & 0.001 & 92 & 235 & 0.391 \\
\hline 46.63 & 215 & 0.001 & 88 & 346 & 0.254 \\
\hline 42.88 & 212 & 0.001 & 15 & 511 & 0.029 \\
\hline 39.44 & 215 & 0.001 & 212 & 674 & 0.315 \\
\hline 38.13 & 224 & 0.001 & 69 & 663 & 0.104 \\
\hline 36.80 & 224 & 0.001 & 11 & 762 & 0.014 \\
\hline 34.32 & 215 & 0.001 & 60 & 1139 & 0.053 \\
\hline 32.95 & 200 & 0.001 & 203 & 1663 & 0.122 \\
\hline 32.53 & 200 & 0.001 & 360 & 1777 & 0.203 \\
\hline 29.77 & 200 & 0.025 & 222 & 6332 & 0.035 \\
\hline 26.09 & 212 & 0.028 & 30 & 9321 & 0.003 \\
\hline 26.04 & 200 & 0.028 & 81 & 10981 & 0.007 \\
\hline 21.64 & 212 & 0.001 & 96 & 7894 & 0.012 \\
\hline 20.56 & 200 & 0.001 & 40 & 12312 & 0.003 \\
\hline 11.22 & 200 & 0.001 & 11545 & $1.5 \times 10^{6}$ & 0.008 \\
\hline \multicolumn{5}{|c|}{ Cumulative Usage Factor: } & 3.688 \\
\hline \multicolumn{5}{|c|}{$\begin{array}{l}\text { Probability of Fatigue Cracking (at } 200^{\circ} \mathrm{C} \& \text { max. stress } 92 \mathrm{ksi} \text { ): } \\
\text { Probability of Fatigue Cracking (at } 200^{\circ} \mathrm{C} \& \text { mid stress } 62 \mathrm{ksi} \text { ): } \\
\text { Probability of Fatigue Cracking (at } 200^{\circ} \mathrm{C} \& \text { min. stress } 33 \mathrm{ksi} \text { ): }\end{array}$} & $\begin{array}{l}1.4 \times 10^{-1} \\
1.1 \times 10^{-1} \\
1.4 \times 10^{-1}\end{array}$ \\
\hline
\end{tabular}

a Max., mid, and min. values represent the stress range where $>80$ of fatigue usage is accumulated. 
Table A-16. Fatigue evaluation for SA-508 low-alloy steel feedwater nozzle of a BWR (Fatigue data from Table 5.131, NUREG/CR-6260)

\begin{tabular}{|c|c|c|c|c|c|}
\hline $\begin{array}{c}\text { Stress } \\
\text { Amplitude (ksi) }\end{array}$ & $\begin{array}{c}\text { Temperature } \\
{ }^{\circ} \mathrm{C} \\
\end{array}$ & $\begin{array}{c}\text { Strain Rate } \\
/ \mathrm{s}\end{array}$ & $\begin{array}{c}\text { Applied } \\
\text { Cycles }\end{array}$ & $\begin{array}{c}\text { NUREG/CR- } \\
\text { 5999 Design Life }\end{array}$ & $\begin{array}{l}\text { Usage } \\
\text { Factor }\end{array}$ \\
\hline 45.00 & 288 & 0.001 & 120 & 121 & 0.992 \\
\hline 50.56 & 200 & 0.100 & 330 & 1292 & 0.255 \\
\hline 38.33 & 200 & 0.0014 & 2470 & 1057 & 2.337 \\
\hline 39.00 & 250 & 0.0016 & 10 & 273 & 0.037 \\
\hline 30.00 & 200 & 0.001 & 10000 & 1603 & 6.238 \\
\hline \multicolumn{5}{|c|}{ Cumulative Usage Factor: } & 9.859 \\
\hline \multirow{3}{*}{\multicolumn{5}{|c|}{$\begin{array}{l}\text { Probability of Fatigue Cracking (at } 200^{\circ} \mathrm{C} \& \text { max. stress } 50 \mathrm{ksi} \text { ): } \\
\text { Probability of Fatigue Cracking (at } 200^{\circ} \mathrm{C} \& \text { mid stress } 38 \mathrm{ksi} \text { ): } \\
\text { Probability of Fatigue Cracking (at } 200^{\circ} \mathrm{C} \mathrm{\&} \mathrm{min.} \mathrm{stress} 30 \mathrm{ksi} \text { : }\end{array}$}} & $7.5 \times 10^{-1}$ \\
\hline & & & & & $7.0 \times 10^{-1}$ \\
\hline & & & & & $5.7 \times 10^{-1}$ \\
\hline
\end{tabular}

Table A-17. Fatigue evaluation for Alloy 600 thermal sleeve from BWR vessel feedwater nozzle (Fatigue data from Table 5.104, NUREG/CR-6260)

\begin{tabular}{cccc}
\hline $\begin{array}{c}\text { Stress } \\
\text { Amplitude (ksi) }\end{array}$ & $\begin{array}{c}\text { Applied } \\
\text { Cycles }\end{array}$ & $\begin{array}{c}\text { NUREG/CR-5999 } \\
\text { Design Life }\end{array}$ & $\begin{array}{c}\text { Usage } \\
\text { Factor }\end{array}$ \\
\hline 222.36 & 10 & 29 & 0.345 \\
175.21 & 110 & 52 & 2.115 \\
147.80 & 20 & 78 & 0.256 \\
133.76 & 210 & 100 & 2.100 \\
95.62 & 2 & 224 & 0.009 \\
55.50 & 220 & 1360 & 0.162 \\
51.26 & 335 & 2194 & 0.153 \\
\multicolumn{4}{r}{ Probability of Fatigue Cracking (at max. stress 222 ksi): } \\
Probability of Fatigue Cracking (at mid stress 178 ksi): & 5.141 \\
\hline Probability of Fatigue Cracking (at min. stress 134 ksi): & $2.3 \times 10^{-3}$ \\
\hline
\end{tabular}

a Max., mid, and min. values represent the stress range where $>80$ of fatigue usage is accumulated. 

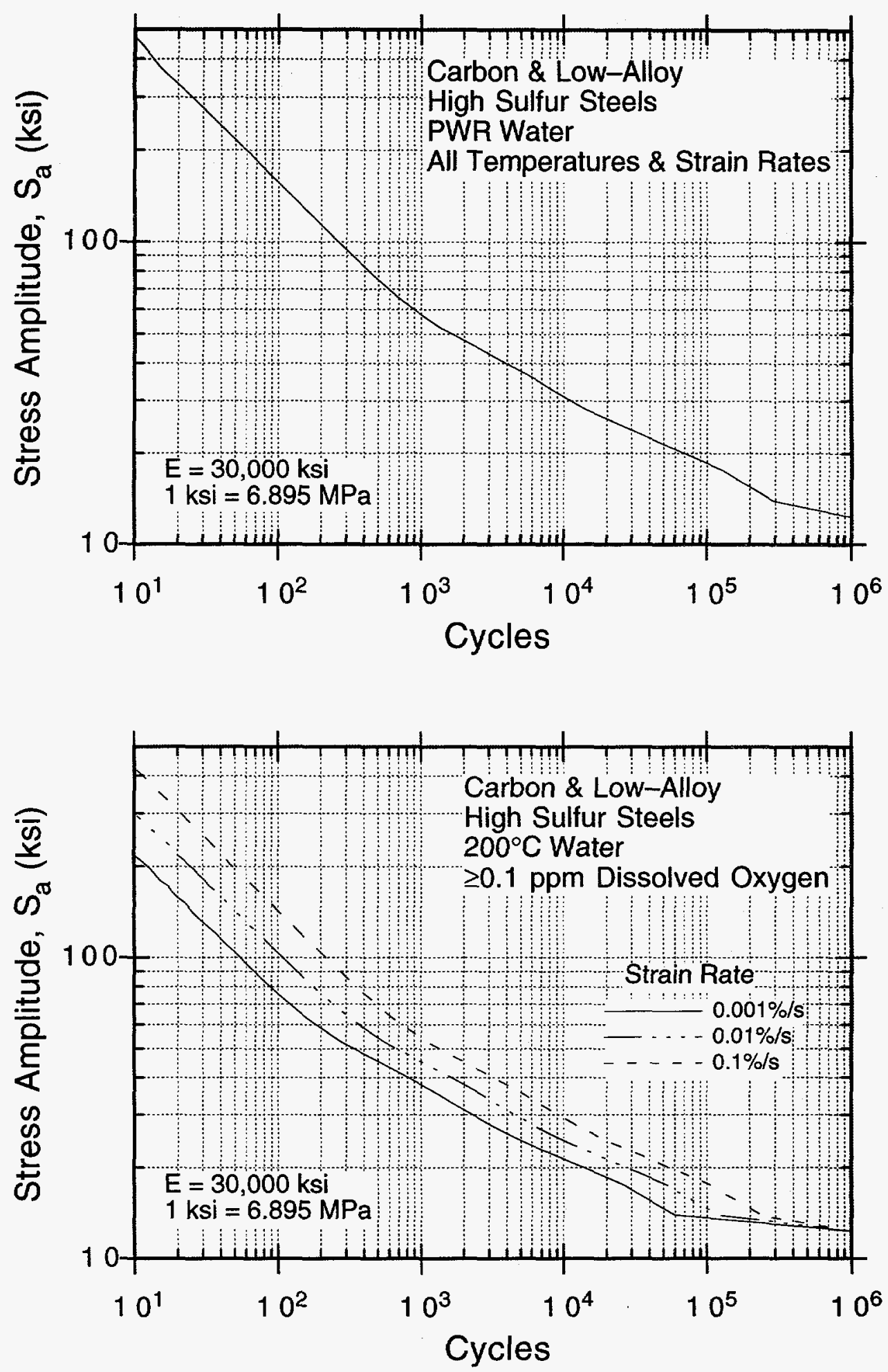

Figure A-1. Proposed interim fatigue design curves for carbon and low-alloy steels in low-DO water typical of PWRs and high-DO water representing a conservative estimate for BWRs 

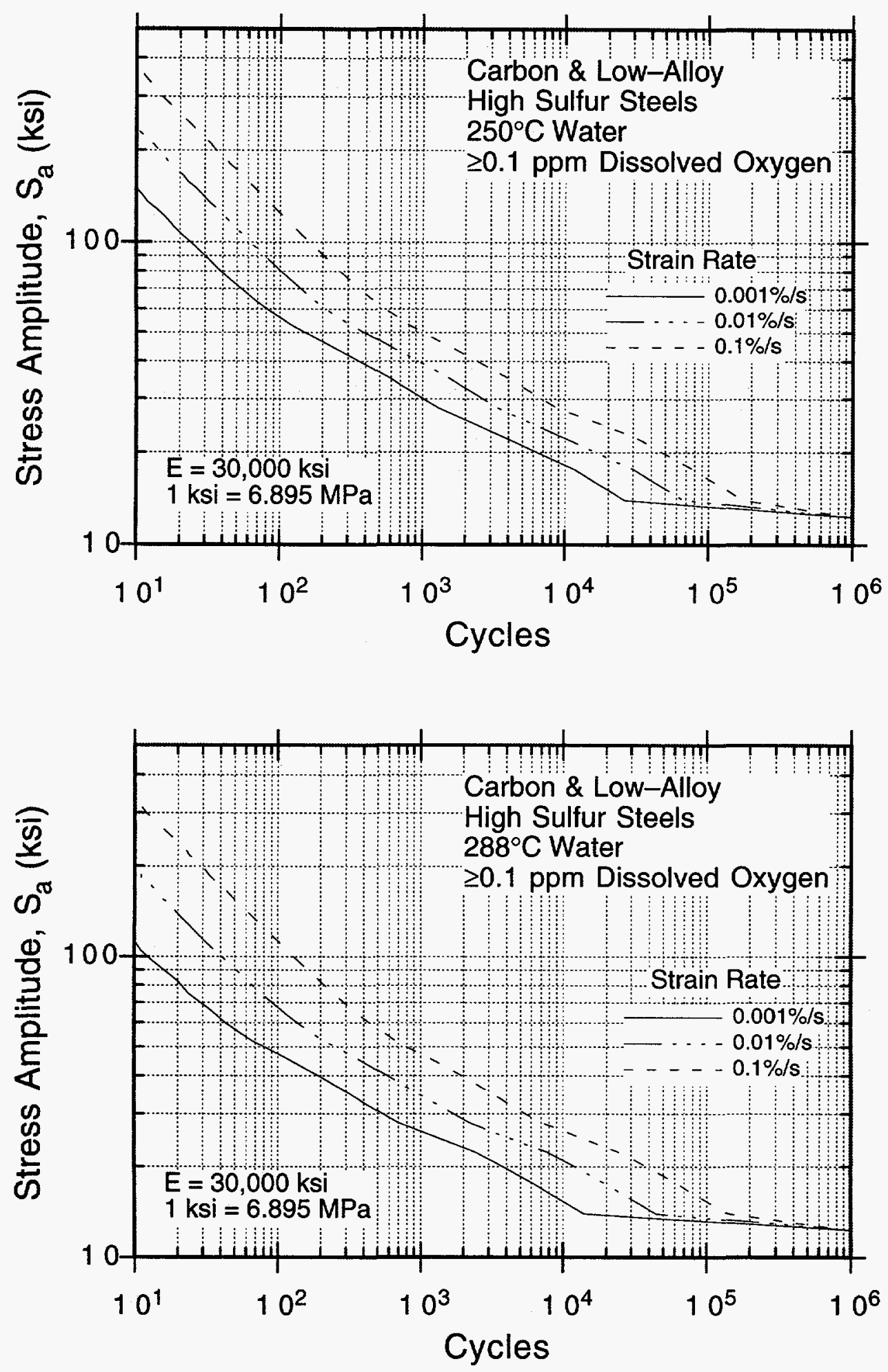

Figure A-1. (Contd.) 


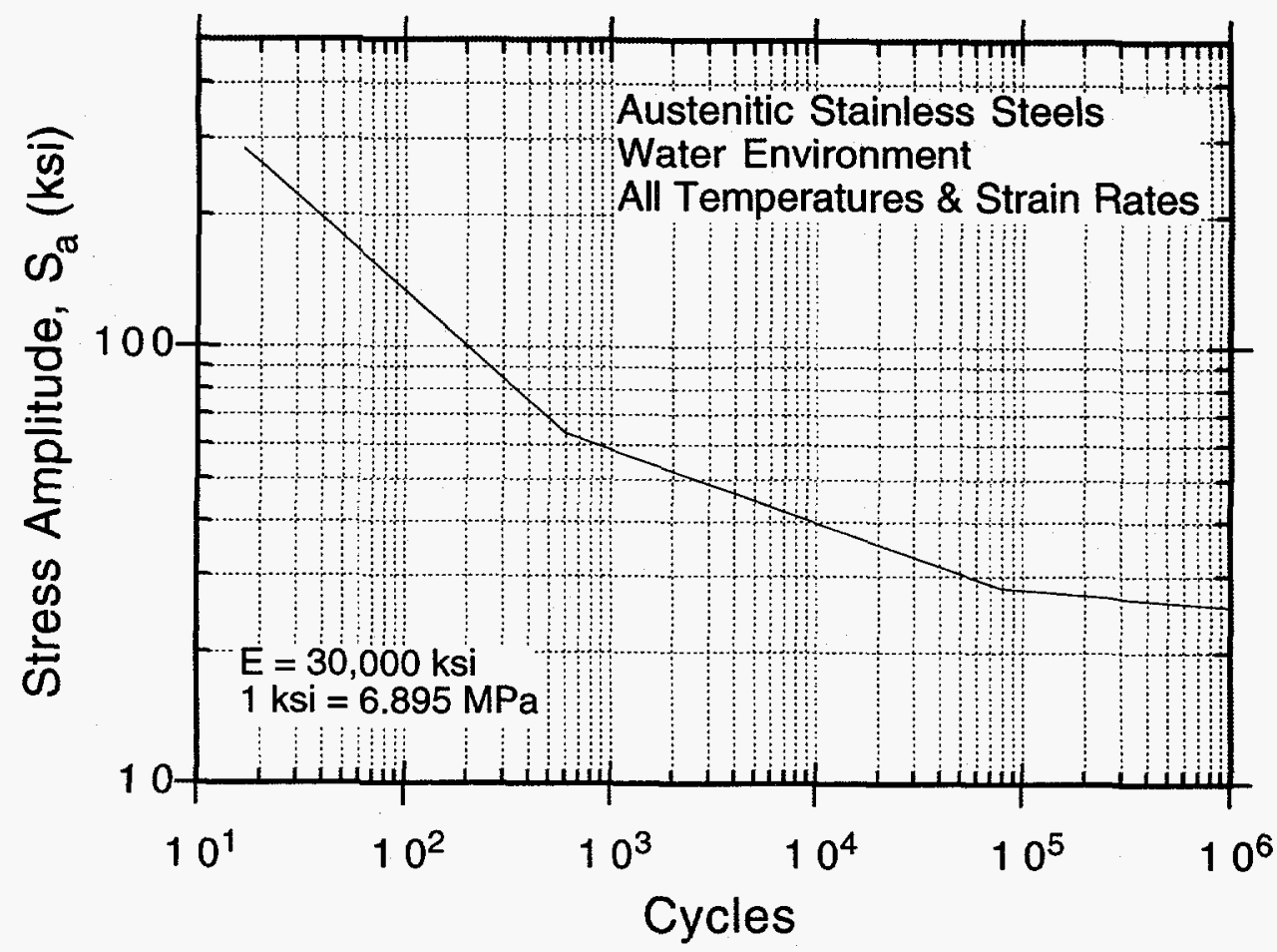

Figure A-2. Proposed interim fatigue design curve for austenitic stainless steels in water 

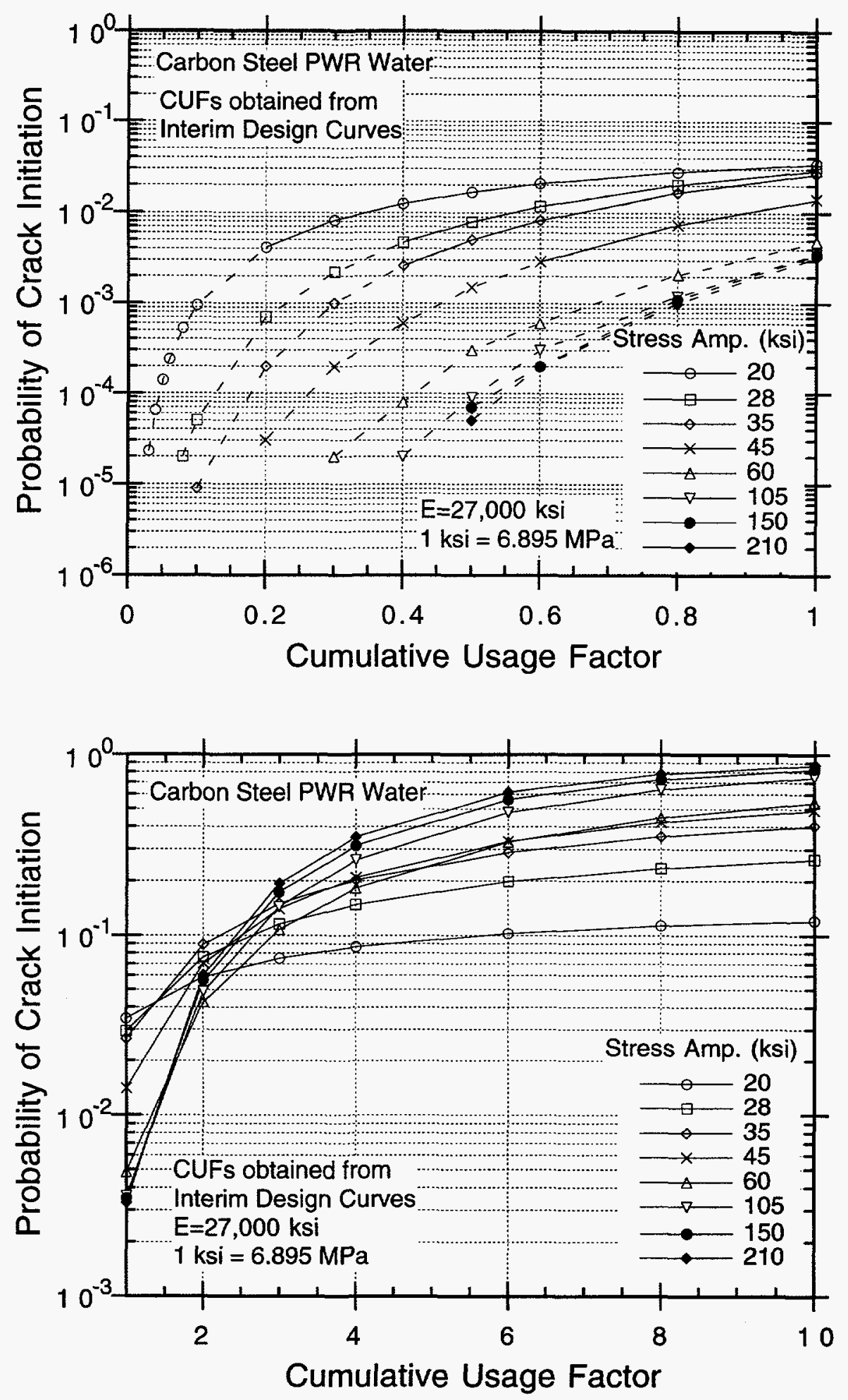

Figure A-3. Probability of fatigue cracking in carbon steel in water with low DO levels (<0.05 ppm) plotted as a function of cumulative usage factor at different applied stress amplitudes 

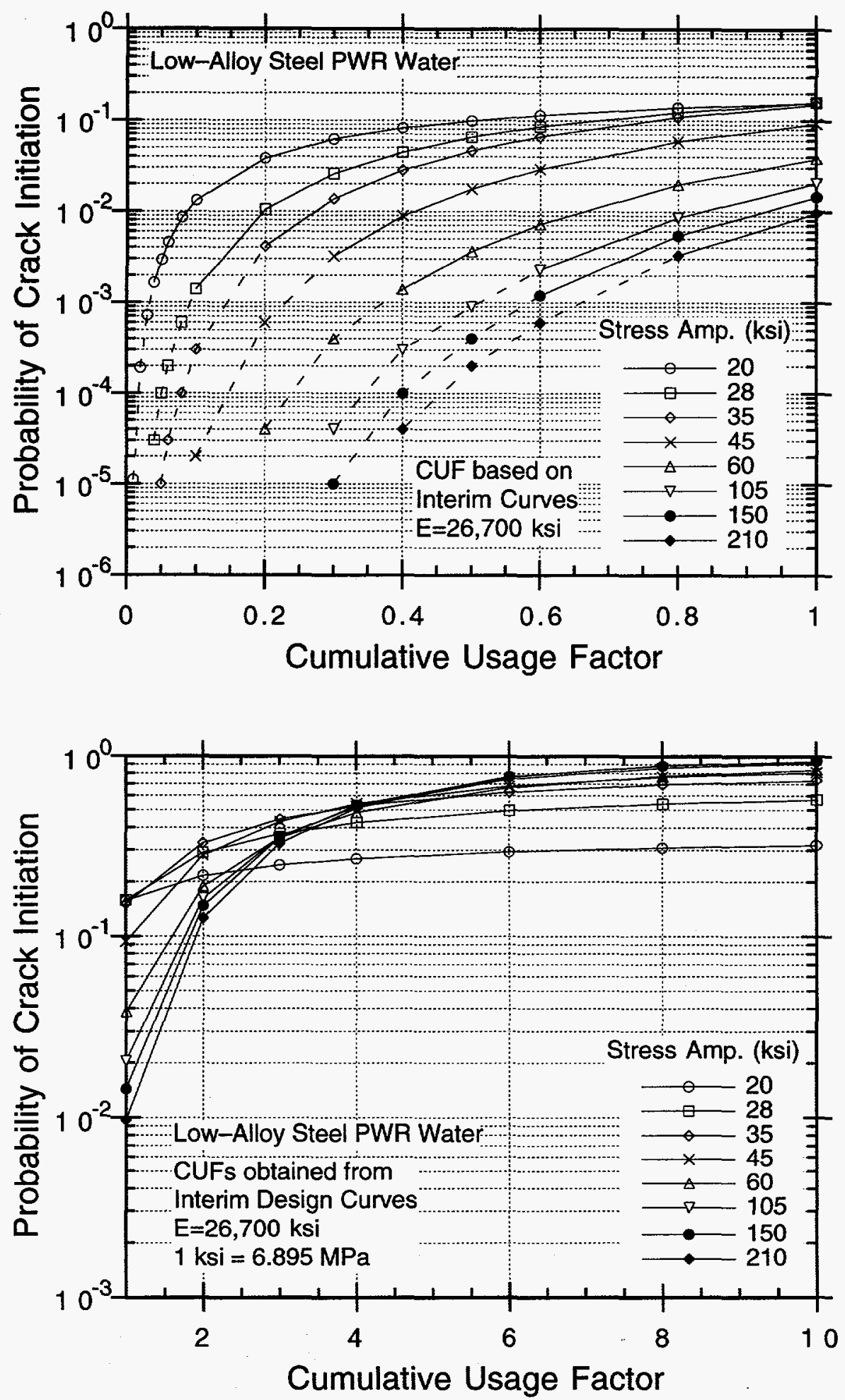

Figure A-4. Probability of fatigue cracking in low-alloy steel in water with low DO levels ( $<0.05 \mathrm{ppm})$ plotted as a function of cumulative usage factor at different applied stress amplitudes 

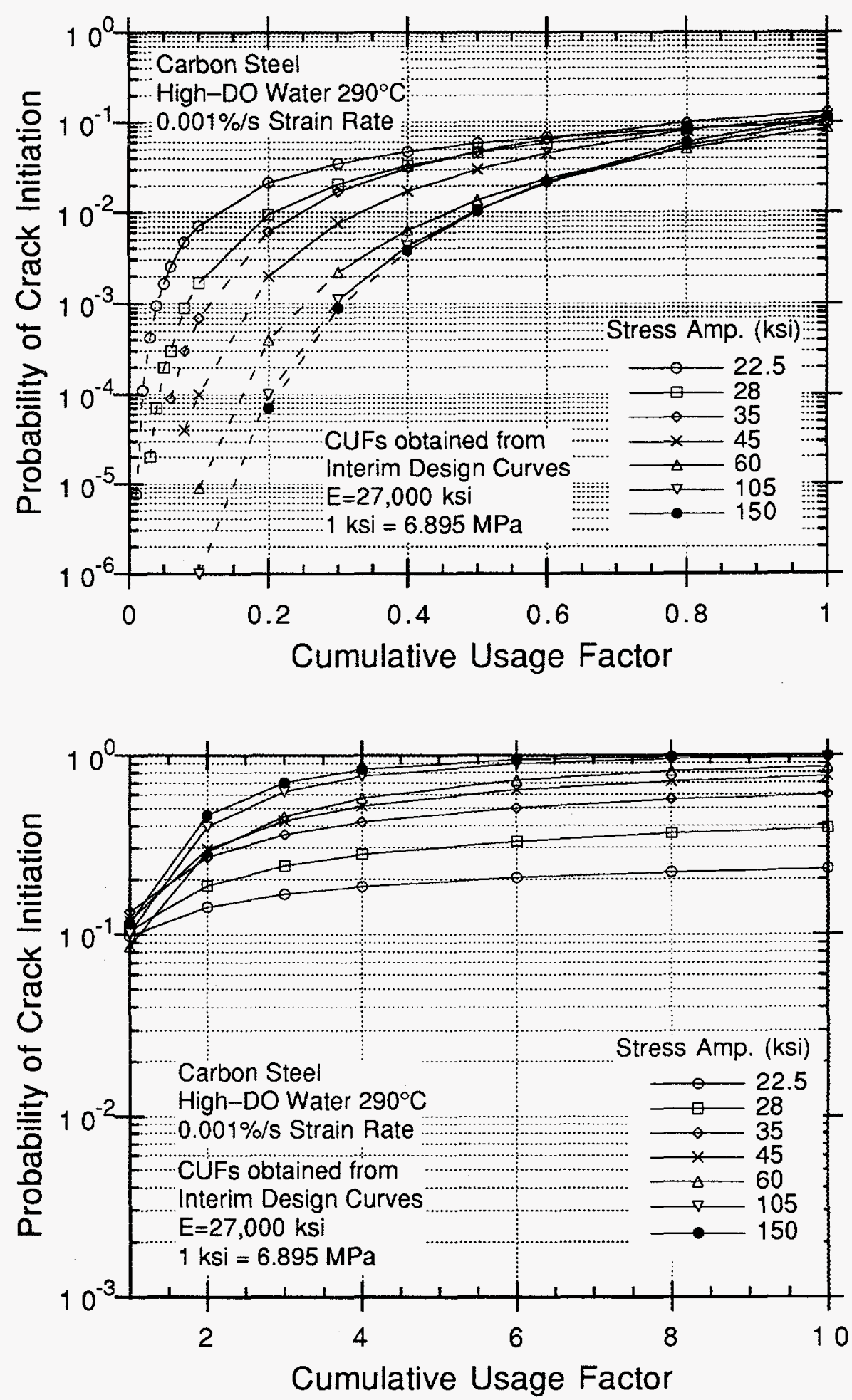

Figure A-5. Probability of fatigue cracking in carbon steel in water with DO levels $\geq 0.5 \mathrm{ppm}$ plotted as a function of cumulative usage factor at different applied stress amplitudes 

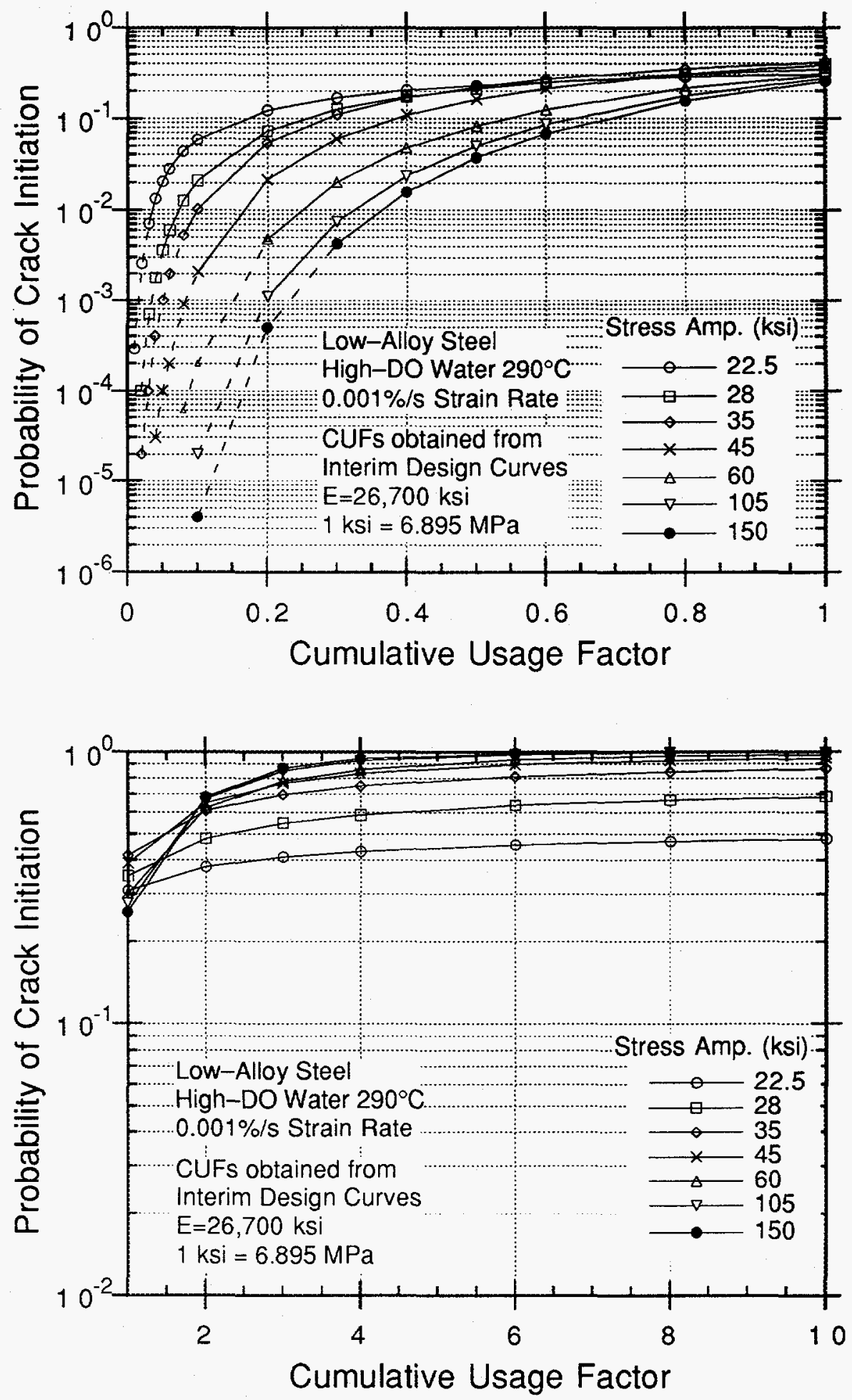

Figure A-6. Probability of fatigue cracking in low-alloy steel in water with $D O$ levels $\geq 0.5 \mathrm{ppm}$ plotted as a function of cumulative usage factor at different applied stress amplitudes 

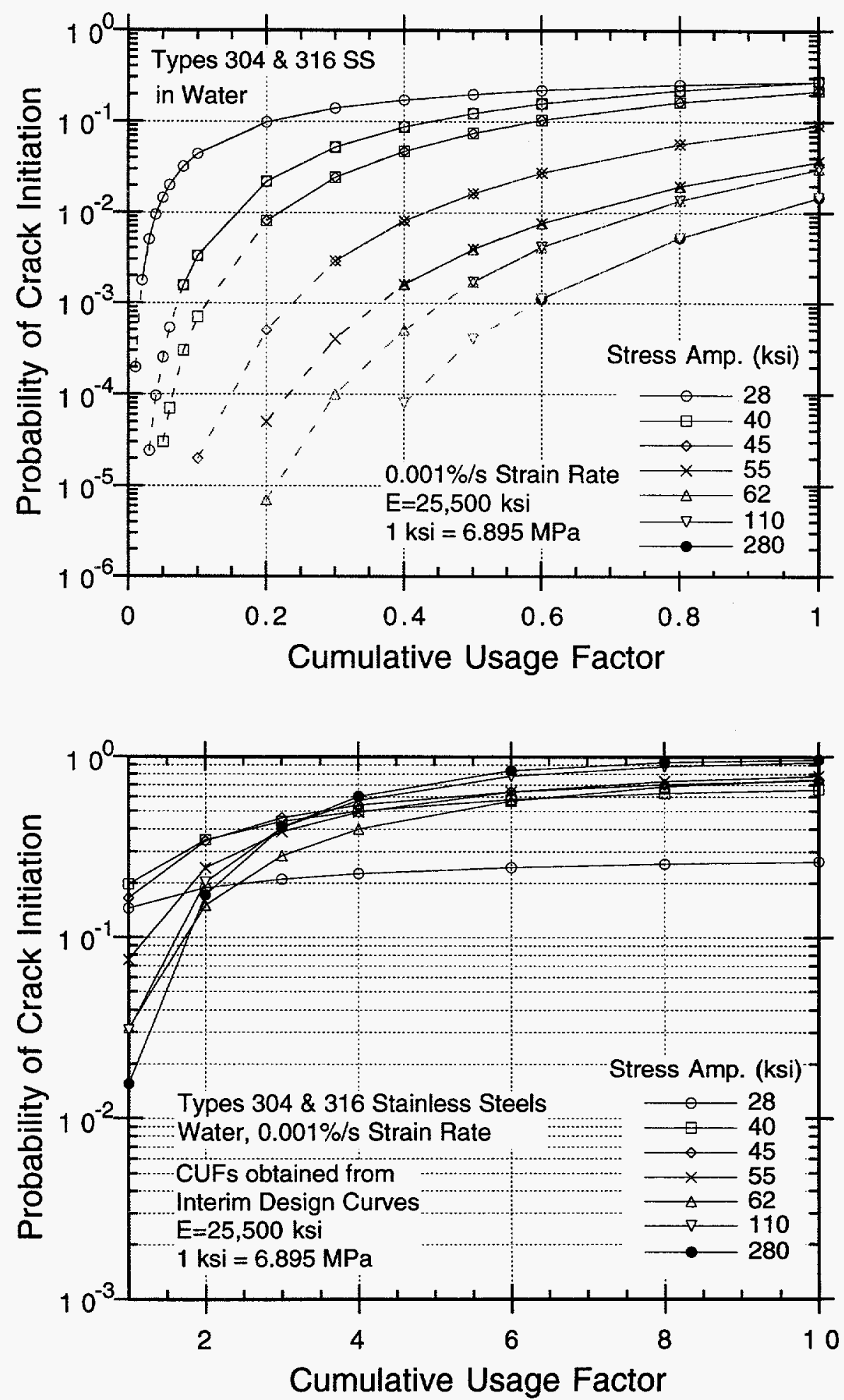

Figure A-7. Probability of fatigue cracking in Types 304 and 316 stainless steel in water plotted as a function of cumulative usage factor at different applied stress amplitudes 

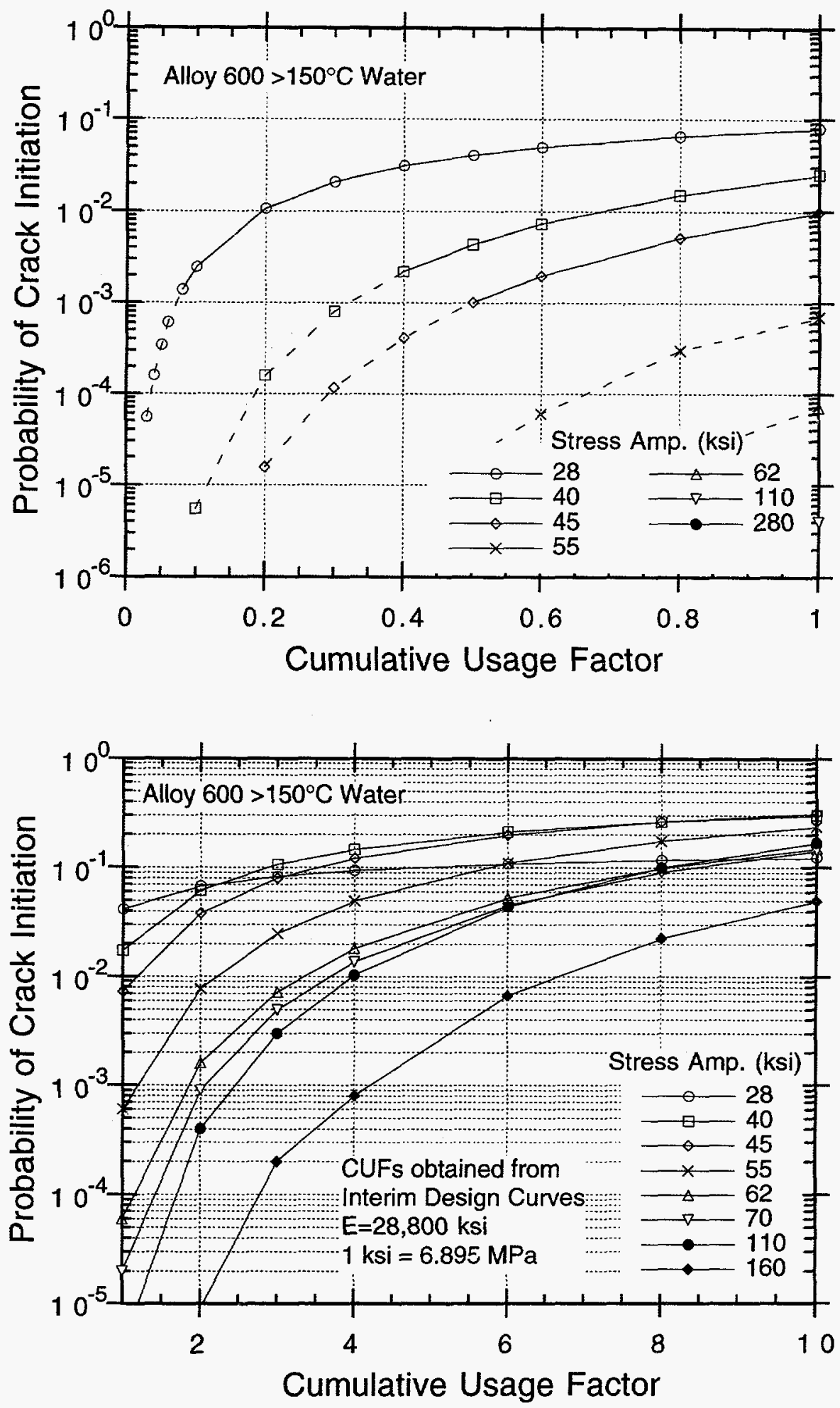

Figure A-8. Probability of fatigue cracking in Alloy 600 in water plotted as a function of cumulative usage factor at different applied stress amplitudes 


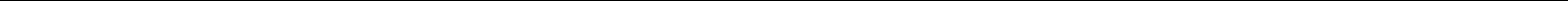




\section{Distribution for NUREG/CR-6335 (ANL-95/15)}

Internal:

O. K. Chopra (20)

T. F. Kassner

J. Keisler (5)

\author{
C. Malefyt \\ R. B. Poeppel \\ W. J. Shack
}

\author{
C. E. Till \\ R. W. Weeks \\ R. Whitfield \\ TIS Files
}

External:

NRC, for distribution per R5

ANL Libraries

ANL-E (2)

ANL-W

Manager, Chicago Field Office, DOE

Energy Technology Division Review Committee

H. K. Birnbaum, University of Illinois, Urbana

R. C. Buchanan, University of Cincinnati, Cincinnati, $\mathrm{OH}$

M. S. Dresselhaus, Massachusetts Institute of Technology, Cambridge, MA

B. G. Jones, University of Illinois, Urbana

C.-Y. Li, Cornell U., Ithaca, NY

S.-N. Liu, Fremont, CA

R. E. Smith, Altran Corp., Huntersville, NC

P. L. Andresen, General Electric Corporate Research and Development, Schenectady, NY

R. G. Ballinger, Massachusetts Institute of Technology, Cambridge, MA

W. H. Bamford, Structural Materials Engineering, Westinghouse Electric Corp., Pittsburgh

R. L. Cowan, General Electric Co., San Jose, CA

G. Cragnolino, Southwest Research Institute, San Antonio, TX

W. H. Cullen, Materials Engineering Assoc., Inc., Lanham, MD

R. Duncan, Combustion Engineering, Inc., Windsor, CT

E. D. Eason, Modeling and Computing Services, Newark, CA

P. Ford, General Electric Corporate Research and Development, Schenectady, NY

M. Fox, APTECH, Tucson, AZ

Y. S. Garud, S. Levy, Inc., Campbell, CA

B. M. Gordon, General Electric Co., San Jose, CA

H. E. Hanninen, Technical Research Centre of Finland

D. Harrison, USDOE, Germantown, MD

J. Hickling, MPA Stuttgart, Stuttgart, Germany

M. Higuchi, Ishikawajima-Harima Heavy Industries Co., Yokohama, Japan

C. Hoffmann, Combustion Engineering, Inc., Windsor, CT

H. S. Isaacs, Brookhaven National Laboratory

A. Jacobs, General Electric Co., San Jose, CA

L. James, Bettis Atomic Power Laboratory, West Mifflin, PA

D. P. Jones, Bettis Atomic Power Laboratory, West Mifflin, PA

T. Karlsen, OECD Halden Reactor Project, Halden, Norway

J. N. Kass, Lawrence Livermore National Laboratory

L. Ljungberg, ASEA-ATOM, Vasteras, Sweden

C. D. Lundin, U. Tennessee, Knoxville 
D. D. Macdonald, Pennsylvania State University, University Park

T. R. Mager, Westinghouse Electric Corp., Pittsburgh

H. Mehta, General Electric Co., San Jose, CA

D. Morgan, Pennsylvania Power and Light Co., Allentown

J. L. Nelson, Electric Power Research Institute, Palo Alto, CA (4)

S. Ranganath, General Electric Co., San Jose, CA

P. M. Scott, Framatome, Paris, France

M. O. Speidel, Swiss Federal Institute of Technology, Zurich, Switzerland

D. M. Stevens, Lynchburg Research Center, Babcock \& Wilcox Co., Lynchburg, VA

D. Tice, AEA Technology, Risley, Warrington, UK

W. A. Van Der Sluys, Research \& Development Division, Babcock \& Wilcox Co., Alliance, OH

E. Venerus, Knolls Atomic Power Laboratory

J. R. Weeks, Brookhaven National Laboratory

D. Winkel, Teleco Oil Field Services, Meriden, CT

S. Yukawa, Boulder, CO 


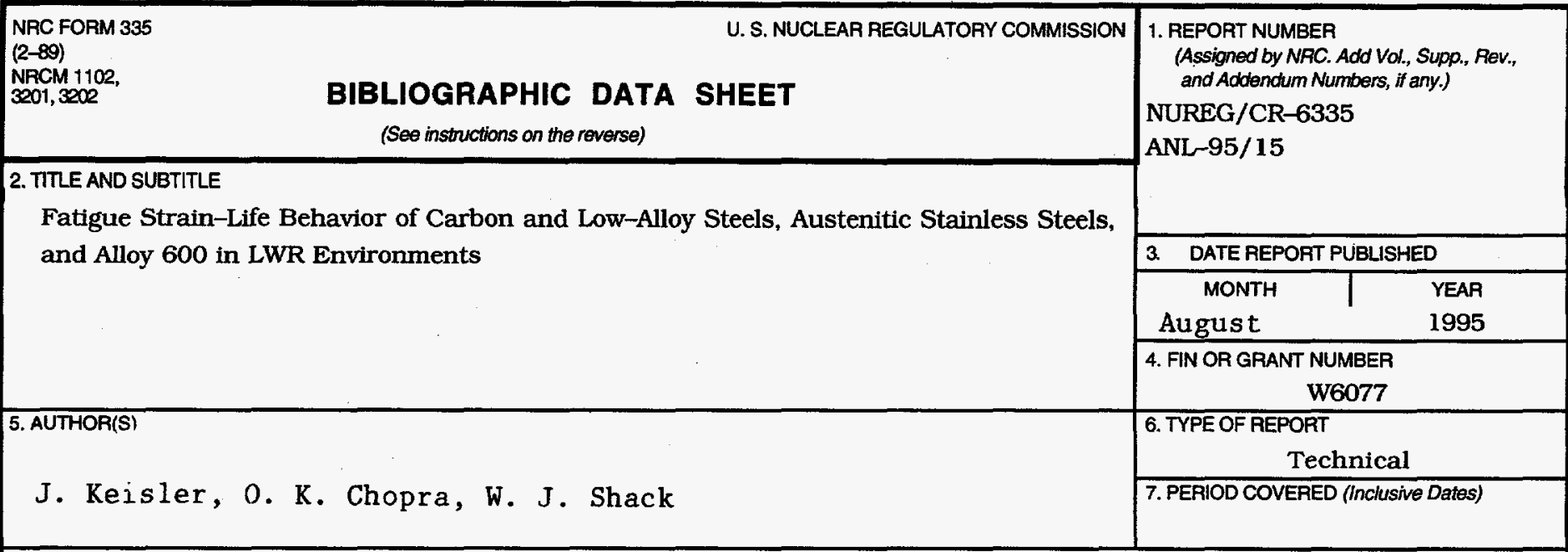

8. PERFORMING ORGANIZATION - NAME AND ADDRESS (If NRC, provide Division, Office or Region, U.S. Nuclear Regulatory Commission, and mailing address; if contractor, provide name and mailing address.)

Argonne National Laboratory

9700 South Cass Avenue

Argonne, IL 60439

9. SPONSORING ORGANIZATION - NAME AND ADDRESS (If NRC, type "Same as above": if contractor, provide NRC Division, Office or Region, U.S. Nuclear Regulatory Commission, and mailing address.)

Division of Engineering Technology

Office of Nuclear Regulatory Research

U.S. Nuclear Regulatory Commission

Washington, DC 20555-0001

10. SUPPLEMENTARY NOTES

\section{ABSTRACT (200 words or less)}

The existing fatigue strain vs. life (S-N) data, foreign and domestic, for carbon and low-alloy steels, austenitic stainless steels, and Alloy 600 used in the construction of nuclear power plant components have been compiled and categorized according to material, loading, and environmental conditions. Statistical models have been developed for estimating the effects of the various service conditions on the fatigue life of these materials. The results of a rigorous statistical analysis have been used to estimate the probability of initiating a fatigue crack. Data in the literature were reviewed to evaluate the effects of size, geometry, and surface finish of a component on its fatigue life. The fatigue $\mathrm{S}-\mathrm{N}$ curves for components have been determined by adjusting the probability distribution curves for smooth test specimens for the effect of mean stress and applying design margins to account for the uncertainties due to component size/geometry and surface finish. The significance of the effect of environment on the current Code design curve and on the proposed interim design curves published in NUREG/CR-5999 is discussed. Estimations of the probability of fatigue cracking in sample components from BWRs and PWRs are presented.

2. KEY WORDS/DESCRIPTORS (List words or phrases that will assist researchers in locating this report.)

Fatigue Strain-Life Curves

Fatigue Design Curves

WWR Environments

Carbon Steels

Low-Alloy Steels

Austenitic Stainless Steels

Alloy 600

Patigue Crack Initiation

Probability of Cracking

Cumulative Usage Factor

IRC FORM 335 (2-89)

\begin{tabular}{|c|}
\hline $\begin{array}{l}\text { 13. AVAILABILITY STATEMENT } \\
\text { Unlimited }\end{array}$ \\
\hline 14. SECURITY CLASSIFICATION \\
\hline (This Page) \\
\hline Unclassified \\
\hline (This Report) \\
\hline Unclassified \\
\hline 15. NUMBER OF PAGES \\
\hline 16. PRICE \\
\hline
\end{tabular}

